\title{
LA PRESUNCIÓN DE NO RESPONSABILIDAD, UNA GARANTÍA DEL AGENTE ADUANAL
}

Miguel Alejandro López OLVERA 
LA PRESUNCIÓN DE NO RESPONSABILIDAD, UNA GARANTÍA DEL AGENTE ADUANAL 


\section{INSTITUTO DE INVESTIGACIONES JURÍDICAS}

Serie Estudios JuRÍdicos, núm. 314

\section{COORDINACIÓN EDITORIAL}

Lic. Raúl Márquez Romero

Secretario Técnico

Lic. Wendy Vanesa Rocha Cacho

Jefa del Departamento de Publicaciones

Wendy Vanesa Rocha Cacho

Edición y formación en computadora

José Antonio Bautista Sánchez

Apoyo editorial

Carlos Martín Aguilera Ortiz

Elaboración de portada 


\section{MIGUEL ALEJANDRO LÓPEZ OLVERA}

\section{LA PRESUNCIÓN \\ DE NO RESPONSABILIDAD, UNA GARANTÍA \\ DEL AGENTE ADUANAL}
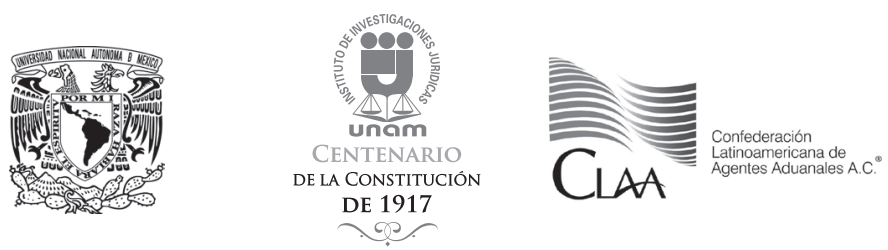

UNIVERSIDAD NAGIONAL AUTÓNOMA DE MÉXICO INSTITUTO DE INVESTIGACIONES JURÍDICAS CONFEDERACIÓN LATINOAMERICANA DE AGENTES ADUANALES 
Primera edición: 15 de noviembre de 2017

DR (C) 2017. Universidad Nacional Autónoma de México

INSTITUTO DE INVESTIGACIONES JURÍDICAS

Circuito Maestro Mario de la Cueva s/n

Ciudad de la Investigación en Humanidades

Ciudad Universitaria, 04510 Ciudad de México

Impreso y hecho en México

ISBN 978-607-02-9670-3

Impreso en Desarrollo Gráfico, S. A. de C. V., Municipio Libre 175-A, colonia Portales, delegación Benito Juárez, 03300 Ciudad de México, tel. 5601 0796. Se utilizó tipo Baskerville en 9, 10 y 11 puntos. En esta edición se empleó papel cream book 57 x 87 de 60 gramos para los interiores y cartulina couché de 250 gramos para los forros. Consta de 1,000 ejemplares (impresión offset). 


\section{CONTENIDO}

Liminar . . . . . . . . . . . . . . . . . . . IX

Felipe Miguel GonZÁLEZ JAIMES

Prólogo ......................... XI

Héctor FIX-FiERRO

Introducción $\ldots \ldots \ldots \ldots \ldots \ldots \ldots \ldots \ldots \ldots \ldots, \ldots \ldots$

PRIMERA PARTE

EL AGENTE ADUANAL

Capitulo primero

Aspectos generales ..................... 7

I. Introducción. . . . . . . . . . . . . . . . 7

II. Persona física $\ldots \ldots \ldots \ldots \ldots \ldots \ldots \ldots \ldots . \quad 8$

III. Autorizado por el Servicio de Administración Tributaria........................ 9

IV. Mediante una patente $\ldots \ldots \ldots \ldots \ldots \ldots \ldots \ldots, 11$

V. Para promover por cuenta ajena el despacho de las mercancías, en los diferentes regímenes aduaneros previstos en la ley....................... 26

VI. Derechos del agente aduanal. .............. 34

Capitulo segundo

La agencia aduanal. . . . . . . . . . . . . . . . . . . 39

I. Introducción. . . . . . . . . . . . . . . . . . . . 39 
II. Constitución de la agencia aduanal . . . . . . . . 40

III. Otorgamiento de una patente corporativa . . . . . . 42

IV. Denominación de "agencia aduanal"......... 43

V. Tipos de agencias aduanales. . . . . . . . . . . 44

VI. Requisitos para la constitución de la agencia . . . . . 45

VII. Autorización de la constitución de la agencia aduanal. 47

VIII. Organización de la agencia aduanal. . . . . . . . . . 48

IX. Disolución de la agencia aduanal . . . . . . . . 51

X. Sanciones a los dependientes de la agencia aduanal . 52

\section{Capitulo tercero}

Responsabilidades de los agentes aduanales y de sus dependientes en relación con el procedimiento de despacho aduanero. . . . . . . 53

I. Introducción. . . . . . . . . . . . . . . . . . . 53

II. Formación del expediente del importador o exportador y determinación del régimen aduanero. . . . . . 55

III. Reconocimiento previo. . . . . . . . . . . . . . 57

IV. Clasificación arancelaria ................ 59

V. Pedimento. ....................... 61

VI. Presentación de mercancías a despacho. . . . . . . . 62

Capitulo cuarto

La vigilancia de los agentes aduanales . . . . . . . . . . 63

I. El principio de la división de poderes. . . . . . . . . 63

II. La división de funciones y las funciones emergentes . . 63

III. La función de vigilancia . . . . . . . . . . . . . . . . . 64

IV. Las normas jurídicas . . . . . . . . . . . . . 68

V. Obligación de los agentes aduanales de aceptar la vi-

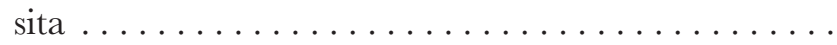


VI. La cancelación de la patente y su relación con los derechos y obligaciones del agente aduanal ....... $\quad 77$

VII. Autoridades competentes en materia de verificación .

\section{SEGUNDA PARTE}

LA GARANTÍA DE LA PRESUNCIÓN DE NO RESPONSABILIDAD EN LOS PROGEDIMIENTOS

ADMINISTRATIVOS SANCIONADORES

EN GONTRA DE LOS AGENTES ADUANALES

Capitulo primero

La presunción de no responsabilidad. . . . . . . . . . . . . . 105

Capitulo segundo

La perspectiva constitucional de la presunción

de no responsabilidad....................... 109

I. Aspectos generales . . . . . . . . . . . . . . . . . . . 109

II. El bloque de constitucionalidad y la presunción de no responsabilidad......................... 113

III. Presunción de no responsabilidad y derecho administrativo sancionador. . . . . . . . . . . . . .

Capitulo tercero

La función de garantía de la presunción de no responsabilidad . . 123

I. Aspectos generales . . . . . . . . . . . . . . . . . . 123

II. En los procedimientos en materia aduanera . . . . . . 127

Capitulo cuarto

La presunción de no responsabilidad como garantía estructural y su incorporación al procedimiento administrativo sancionador mexicano . . . . . . . . . . . . . . . . . . . . . . . 133

I. Aspectos generales . . . . . . . . . . . . . . . . . 133 
II. Aspectos técnicos . . . . . . . . . . . . . . 136

III. Aspectos sustantivos . . . . . . . . . . . . . . . . . . . 139

Capitulo quinto

Aplicación de la garantía de presunción de no responsabilidad en el ámbito administrativo. . . . . . . . . . . . . .

Capitulo sexto

Hipótesis relevantes e implicaciones prácticas en las actividades del agente aduanal que exigen la aplicación de la presunción de no responsabilidad. . . ...................

Bibliografía ...................... 161 


\section{LIMINAR}

La Confederación Latinoamericana de Agentes Aduanales (CLAA) y el Instituto de Investigaciones Jurídicas de la UNAM, con el objetivo de transparencia y certeza jurídica para las funciones del agente aduanal, realizaron el presente estudio donde se fundamenta y reconoce el derecho a la presunción de no responsabilidad.

La investigación inició en 2015, cuando el A. A. Luis Guillermo Silva y Gutiérrez, quien presidía la CLAA, fijó los objetivos de este estudio jurídico e invitó al Instituto de Investigaciones Jurídicas de la UNAM. Posteriormente, la CLAA logró concluir este gran proyecto, participando en la revisión jurídica de la investigación.

El resultado de este esfuerzo es el estudio que el lector tiene en sus manos, que hace referencia a la garantía de presunción de inocencia y su aplicación en los procedimientos administrativos sancionadores en materia aduanera, lo que conlleva a una presunción de no responsabilidad en el ámbito administrativo, teniendo como finalidad preservar en el destinatario de la norma un estado de no reproche jurídico frente a actos de los órganos de poder en ejercicio del ius puniendi hasta en tanto se mantenga incólume ese derecho y no sea desvirtuado a través de un procedimiento administrativo.

A. A. Felipe Miguel González Jaimes Presidente de la Confederación Latinoamericana de Agentes Aduanales 


\section{PRÓLOGO}

De acuerdo con cifras de la Organización Mundial de Comercio (OMG), el comercio mundial de mercancías y servicios comerciales casi se duplicó en un periodo de apenas diez años (2005-2015). La exportación total de mercancías por los miembros de la OMC alcanzó 16.2 billones de dólares de los Estados Unidos en 2015, mientras que la de servicios comerciales tuvo un monto de 4.68 billones, es decir, una suma de casi 21 billones de dólares, que equivalen aproximadamente al 24 por ciento del producto interno bruto (PIB) del mundo; ese año, el crecimiento de las exportaciones fue de 3 por ciento, y el de las importaciones de 2.4 por ciento. Apenas quince años antes, en 2000, las cifras correspondientes eran de 6.2 billones de dólares por exportación de mercancías, y 1.4 billones por exportación de servicios comerciales. Aun tomando en cuenta el crecimiento de los precios y la fluctuación de las monedas, se puede advertir que el comercio mundial ha tenido un crecimiento muy notable - se diría espectacular - de casi tres veces en el periodo.

Cierto es que el crecimiento apuntado no ha sido siempre constante, pues tuvo una caída importante con la crisis económica de 2008 y una disminución apreciable en 2015. Además, en el horizonte mundial se advierten signos preocupantes que parecen anunciar, cuando menos, una revisión del modelo de comercio abierto por algunos países importantes, principalmente los Estados Unidos, por lo que resulta difícil hacer algún pronóstico preciso sobre las tendencias de largo plazo, pero cuesta trabajo imaginar que el comercio pudiera perder rápidamente la importancia que tiene en la actualidad para la economía mundial y, 
sobre todo, para algunos países de rápido desarrollo, como lo es China.

Por lo que se refiere a México, la misma fuente consigna que nuestro país ocupó el lugar número 13 mundial en el valor de sus exportaciones, y el 12 en el de las importaciones, aunque según las cifras correspondientes a los servicios comerciales, nuestro país ocupa los lugares 39 y 33, respectivamente. Las estadísticas de comercio exterior del gobierno mexicano (Secretaría de Economía) indican que las exportaciones totales de México crecieron, de casi 52 mil millones de dólares en 1993, a casi 381 mil millones en 2015, una multiplicación de más de siete veces en términos nominales. De ese monto, el 81.1 por ciento se dirige a los Estados Unidos. Las importaciones han crecido, en el mismo lapso, de 65 mil millones a 395 mil millones de dólares en 2015, aunque sólo el 47.3 por ciento lo son de compras a los Estados Unidos. El comercio con China ha aumentado de manera impresionante, con importaciones de casi 70 mil millones de dólares y exportaciones de apenas 4 mil 900 millones ese mismo año.

Una buena parte del crecimiento de las exportaciones se ha debido al éxito del Tratado de Libre Comercio de América del Norte (TLCAN) con Canadá y los Estados Unidos, el cual ha tenido otros impactos benéficos en la modernización tanto de la economía mexicana como de su régimen jurídico. Veintitrés años después de su entrada en vigor, el nuevo gobierno de los Estados Unidos - que encabeza desde comienzos de 2017 el empresario Donald Trump - ha anunciado su intención de renegociar el Tratado, por considerarlo desventajoso para su país, y si la renegociación no resulta favorable para sus intereses, denunciarlo del todo. Con independencia de las ventajas y desventajas relativas que el Tratado tiene para los países integrantes (en efecto, hay una importante diferencia en la balanza comercial con los Estados Unidos, favorable a México, pero hay que considerar que parte de ese comercio son movimientos "internos" entre las empresas, así como tomar en cuenta también la balanza de pagos), 
sería una falta grave de visión económica dejar de ver el funcionamiento de este instrumento en términos de una economía regional cada vez más integrada y en competencia con otras regiones del mundo.

Desde el punto de vista del control y la administración del comercio por el Estado nacional, surgen varios desafios e incluso verdaderas paradojas. Por un lado, la globalización requiere que las fronteras nacionales sean cada vez menos un obstáculo para el traslado de mercancías y servicios, que es el principio en que se basa el libre comercio. Por el otro, por razones políticas y económicas, e inclusive fiscales, pero cada vez más también de seguridad, el Estado trata de ejercer diversos controles sobre las mercancías y los productos que salen o entran en su territorio. Crecientemente, y sólo por el volumen de mercancías manejadas y la necesidad de su eficiente despacho, las autoridades aduaneras se ven obligadas a recurrir a los controles selectivos y, sobre todo, al uso de la tecnología. La paradoja reside en que estas barreras no parecen existir para el comercio irregular (que es una forma de competencia desleal) o el francamente ilegal, que resulta muy dificil de combatir por las grandes ganancias que pueden obtenerse de él. También es de advertirse que mucho del comercio que denominamos "internacional" consiste realmente en movimientos de mercancías y servicios entre las filiales de las empresas multinacionales, por lo que, en cierto sentido, se trata de un comercio que podríamos llamar también "interno".

Las observaciones anteriores tienen el modesto propósito de situar en contexto y perspectiva el tema central de esta obra dedicada a la figura del agente aduanal. En la medida en que el comercio exterior siga creciendo, y al mismo tiempo aumentan también las presiones para lograr que el intercambio de bienes y servicios se haga de manera controlada y regulada, en esa misma medida crecerán la importancia y las responsabilidades de este agente, intermediario entre los actores económicos particulares y las autoridades aduaneras del Estado, por lo que comparte carac- 
terísticas de ambos. Dicho en otras palabras: al agente aduanal le corresponde gestionar la difícil combinación de los principios antagónicos de la facilitación y el control de los flujos del comercio exterior en el marco de los regímenes aduaneros vigentes en un país determinado, en este caso, el nuestro. De ahí también la utilidad de la obra que se comenta, la cual presenta de manera sencilla y sintética, pero también bastante completa y no exenta de observaciones críticas, la reglamentación vigente en nuestro país sobre el agente aduanal, con útiles adiciones y comentarios de derecho comparado, que sirven para identificar de manera más precisa las características de la figura en nuestro ordenamiento.

No tendría sentido tratar de hacer un rápido repaso de los temas abordados en el libro, ya que se trata de un trabajo accesible y breve. Por ello, estas líneas se limitarán a comentar un par de cuestiones interesantes, planteadas en sendas partes de la obra.

Por lo que toca a la primera parte, se hace notar en repetidas ocasiones la contradicción que parece implicar, por un lado, que la función de agente aduanal solamente puede ser ejercida por una persona física, la que recibe la correspondiente autorización (llamada anacrónicamente "patente" en nuestra ley) del poder público justamente en razón de que los candidatos cuentan con antecedentes de honorabilidad y confiabilidad para realizar sus delicadas tareas. Por el otro, destaca la necesidad de que la misma función se constituya como una verdadera empresa, con asociados y empleados, que pueda funcionar de manera económica y eficiente, pues en los hechos se trata de una función que, por su carácter técnico y masivo, exige cada vez más una organización compleja, apoyada por la tecnología. Por ello, en la obra se insiste repetidas veces en la posibilidad y en la conveniencia de que se otorgara una patente corporativa, es decir, a una persona moral, lo que resolvería una aparente contradicción que se manifiesta en discrepancias notorias, como el hecho de que el servicio sea prestado por los agentes, pero la facturación corra por cuenta de la persona moral. 
La propuesta anterior tiene sentido y lógica, y no carece de referentes en la vida social contemporánea. Por ejemplo, las funciones del notario y las del médico dependen de manera principal de la honorabilidad, competencia y, sobre todo, la confiabilidad - es decir, las cualidades personales y profesionales - de quienes las ejercen, al tiempo que resulta indispensable que su prestación se organice eficientemente. Asuman o no la forma jurídica correspondiente, tanto el despacho del notario público como el consultorio del médico acaban funcionando como empresas, y por ello muchos se organizan corporativamente.

Yendo un paso más allá, si las cualidades personales y profesionales del agente aduanal resultan centrales para la función, puede pensarse en un esquema en que, organizados en una persona moral que reciba autorización del poder público para desempeñarse como agencia aduanal, los asociados personas físicas tengan que cumplir, de todos modos, con requisitos similares a los que se le exigen actualmente al agente aduanal. Una ventaja de este esquema sería la continuidad, renovación y actualización de las funciones de despacho aduanal en el marco de una organización estable y visible. Para efectos de impedir que la responsabilidad al interior de la misma se diluya, se podría establecer un porcentaje mínimo de participación que limitaría el número de asociados. La aceptación de una "patente corporativa" tendría también consecuencias para la cuestión de la responsabilidad, que hasta el momento sólo es de tipo individual.

La segunda parte de la obra examina un tema de gran interés y alcance: la vigencia de la llamada "presunción de inocencia" en el procedimiento administrativo sancionador aplicado a las funciones de agente aduanal. El problema subyacente es claro: de acuerdo con el régimen vigente, la autoridad aduanera puede suspender la patente del agente si tiene indicios de que éste ha incurrido en faltas o irregularidades en el desempeño de la función, sin que se escuche previamente su opinión y, sobre todo, sin que se haya determinado todavía su responsabilidad, es decir, se le 
aplica una especie de sanción provisional sin que se hayan configurado con certeza los elementos que justificarían dicha sanción. Lo grave es que dicha suspensión puede durar un largo tiempo, al final del cual una determinación de no responsabilidad del agente aduanal probablemente ya no le permitirá retomar el ejercicio de sus funciones en las condiciones prevalecientes al momento de la suspensión. La pregunta que hay que contestar, entonces, es si se puede o se debe trasladar la "presunción de inocencia" del campo penal, donde tiene su origen y principal aplicación, al ámbito del derecho administrativo sancionador.

Para situar la pregunta y su posible respuesta en contexto, resulta conveniente saber que la "presunción de inocencia" apenas se incluyó de manera expresa en nuestra Constitución mediante la reforma del 18 de junio de 2008. Otro elemento importante para tomar en cuenta es la reforma en materia de derechos humanos del 10 de junio de 2011, la cual impone a todas las autoridades públicas la obligación de promover, respetar, proteger y garantizar los derechos humanos, otorgando a las personas en todo momento el trato más favorable (el llamado principio "pro persona"). Para decirlo en otros términos: la reforma de 2011 implica un nuevo paradigma, como se le ha llamado, que ordena la vigencia plena y transversal de todos los derechos, por lo que resulta razonable proponer que dicha presunción sea válida también para los ámbitos jurídicos no penales, siempre que estén de por medio los derechos fundamentales de las personas, principalmente, como se señala de manera atinada al inicio del capítulo primero de la segunda parte, cuando están de por medio la dignidad humana, la libertad, la honra y el buen nombre, que podrían resultar vulnerados por actuaciones penales o disciplinarias irregulares.

La Suprema Corte de Justicia, a través de la Primera Sala, ha dado una respuesta a esta interrogante, la que se cita en el texto de la obra, en el sentido de que el principio de "presunción de inocencia" puede hacerse extensivo al derecho administrativo 
sancionador, pero sólo "en cierta medida", es decir, que requiere modulaciones para hacerlo compatible con el contexto institucional en el que se pretenda aplicar, "en tanto existen importantes diferencias entre un proceso penal y un procedimiento administrativo sancionador". En vista de tales diferencias, sería conveniente pensar en una denominación distinta para el principio porque, como señala la misma Corte, es "inherente al derecho penal": la palabra "inocencia" solamente se utiliza en relación con la culpabilidad en materia penal. Quizá podría hablarse del principio de "presunción de no responsabilidad", para darle un alcance más general.

Otro principio estrechamente vinculado con el de presunción de no responsabilidad en esta materia es el de proporcionalidad. Este último principio exige que todas las intervenciones del poder público que afecten los intereses o derechos de los particulares sean proporcionales, es decir, que haya una adecuación entre medios y fines, que la intervención sea necesaria y que implique la mínima afectación posible. Desde este punto de vista, también puede cuestionarse la suspensión provisional de la patente de un agente aduanal en los términos de su regulación actual.

En todo caso, queda claro que sí es necesario ajustar esta parte de nuestro ordenamiento, pero la cuestión que se suscita es la de encontrar la configuración específica que haga justicia a los derechos del agente aduanal, al mismo tiempo que tome en cuenta la naturaleza de su función, la que, de acuerdo con la Corte, no es la mera actividad de un particular, sino una "actividad privada de interés público". De ello deriva la necesidad de hacer un balance entre los derechos del agente aduanal y el interés público en su función. Podría pensarse en un esquema en el que al agente aduanal se le otorgue siempre audiencia previa, y si la autoridad decide aplicar la suspensión de la patente como medida precautoria, esta determinación no resulte dañina para terceros ni perjudique desproporcionadamente al agente aduanal, para lo cual podría pensarse en que se mantenga el ejercicio de la paten- 
te mediante el otorgamiento de una garantía, de modo similar, aunque inverso, a lo que prevé la Ley de Amparo cuando el llamado tercero perjudicado tiene interés en la subsistencia del acto reclamado y otorga para ello una garantía por los perjuicios que podrían causarse al quejoso si éste llegara a tener la razón. Así, en caso de determinarse la responsabilidad del agente aduanal, sus efectos serían retroactivos para él (no para sus clientes) y la garantía se haría efectiva, quedando desde luego abierta la vía judicial para revisar la constitucionalidad y la legalidad de la sanción.

La revisión de los derechos y responsabilidades de la figura del agente aduanal debería llevarse a cabo dentro de un proceso de actualización general del sistema aduanero del país, tanto más necesaria cuanto mayor es la velocidad con la que se producen los cambios en el comercio mundial y en los sistemas empresariales y tecnológicos que los acompañan. La Ley Aduanera vigente se publicó en diciembre de 1995, y si bien se ha reformado y actualizado de manera importante en varias ocasiones, la última reforma significativa es de diciembre de 2013. La posible renegociación del TLCAN en los próximos tiempos ofrecerá la oportunidad de revisar nuevamente nuestro régimen aduanero y de actualizar su reglamentación, como en su momento la negociación y entrada en vigor del Tratado, así como el inicio de la OMC, impulsaron la expedición de la ley vigente. Como ha sucedido en las últimas décadas en otros ámbitos económicos y comerciales, los instrumentos internacionales en la materia pueden servir como un punto de referencia conveniente para que nuestro país mantenga abierto el orden jurídico nacional a las normas y las prácticas más avanzadas en el plano internacional.

En síntesis, para quienes tengan interés en la figura del agente aduanal, el libro ofrece un panorama breve y completo sobre ella, planteando no sólo una descripción del régimen jurídico aplicable, sino también algunos temas para la reflexión futura, como los que se han destacado en este breve prólogo. En este sentido, resulta un estudio estimulante que tiene implicaciones para 
un ámbito más amplio y general de problemas, como los que derivan del derecho administrativo sancionador, que son de relevancia para todos los ciudadanos y no solamente para los agentes aduanales o para quienes, por los motivos que sean, se vean precisados a recurrir a sus servicios. Su importancia para el comercio y la economía del país está fuera de duda, por lo que debemos congratularnos de la publicación de este útil estudio.

Héctor FIX-FIERRO 


\section{INTRODUGCIÓN}

El agente aduanal es una persona que desempeña un papel muy importante en la compleja cadena de muchos de los procedimientos que se realizan en la aduana y que son apoyo indispensable para los importadores y exportadores.

Es por ello que resulta de la mayor importancia este estudio, en virtud de que, en la actualidad, el papel del agente aduanal ha tomado tal relevancia que, por lo menos, los temas que se abordan en este libro deben ser puestos a debate.

El estudio lo enfocamos en analizar la situación actual del agente aduanal frente a las actividades que desarrolla en los complejos procesos del comercio internacional que se realizan en las aduanas. También se aborda la garantía de la presunción de inocencia y su aplicación en los procedimientos administrativos sancionadores en contra de agentes aduanales, que hemos preferido denominar como "presunción de no responsabilidad".

La obra se divide en dos partes. La primera la hemos dedicado a realizar un estudio respecto de la naturaleza jurídica del agente aduanal. La segunda comprende el análisis de la figura de la presunción de inocencia y su aplicación en los procedimientos administrativos sancionadores en contra de los agentes aduanales.

La primera parte se divide en cuatro capítulos. En el primero se realiza un análisis de los diferentes aspectos más relevantes de la figura del agente aduanal, entre los cuales se puede mencionar: su denominación; la autoridad que otorga la patente; las diferentes denominaciones que le ha dado la ley a través de la historia; los requisitos para obtener la patente; los requisitos para operar, y los derechos que tiene en su carácter de agente aduanal. 
En el segundo capítulo se analiza la figura de la agencia aduanal y se propone un esquema para que sea incorporado, como un capítulo o sección, dentro de la Ley Aduanera.

En este segundo capítulo se estudian las legislaciones chilena y colombiana, por ser dos países latinoamericanos y, además, por ser las dos únicas que tienen una regulación expresa y más o menos exhaustiva de las agencias aduanales. No encontramos bibliografía dentro de los estudios de derecho aduanero que analice o que describa cómo funciona o cómo está regulada una agencia aduanal, ni siquiera en México.

Como explicamos en el propio capítulo, la constitución, la organización y el funcionamiento de las agencias aduanales en México se encuentran en normas de otras materias, por lo que este segundo capítulo representa un aporte muy importante para el debate académico.

En el tercer capítulo se describe y analiza el procedimiento del despacho aduanero, con particular énfasis en las responsabilidades del agente aduanal y de las personas que intervienen en ese procedimiento.

En el cuarto capítulo se estudia lo relativo a la función de vigilancia, por parte del Estado, de las actividades de los agentes aduanales. Se destaca la relevancia del principio de la división de poderes; de la función de vigilancia y su caracterización como función púbica; la competencia de las diferentes autoridades para realizar dicha actividad, así como la clasificación de la vigilancia en relación con las obligaciones que tienen que cumplir los agentes aduanales.

La segunda parte, que corresponde al estudio de la garantía de la presunción de no responsabilidad, se divide en seis capítulos. En cada uno de ellos se analizan diferentes aspectos de esta importante garantía, que incluyen su definición; las bases constitucionales y convencionales; su aplicación en los procedimientos en materia aduanera, destacando que las instancias jurisdiccionales nacionales e internacionales ya se han pronunciado en el sentido de aplicarla en los procedimientos administrativos sancio- 
nadores. En términos generales, se puede decir que se realizó un análisis profundo y crítico de la no aplicación, en la actualidad, de esa garantía en los procedimientos de cancelación de la patente, argumentos que son igualmente válidos para los procedimientos de suspensión del agente y de inhabilitación.

Al final del estudio se incluye la bibliografía consultada para su realización. 
Este libro forma parte del acervo de la Biblioteca Jurídica Virtual del Instituto de Investigaciones Jurídicas de la UNAM www.juridicas.unam.mx https://biblio.juridicas.unam.mx/bjv

Libro completo en: https://goo.gl/qeUiEB

\section{PRIMERA PARTE}

\section{EL AGENTE ADUANAL}

DR (c) 2017. 


\section{ASPECTOS GENERALES}

\section{INTRODUCGIÓN}

La figura del agente aduanal surge en los ordenamientos jurídicos no sólo para presentar los documentos para el despacho de mercancías de los importadores/exportadores, pues éstos pueden solicitar el despacho aduanero de sus mercancías por sí mismos o a través de un representante disímil al agente aduanal.

Sin embargo, tanto los exportadores como los importadores, al carecer de los conocimientos y prácticas en la materia, por el complejo sistema del comercio exterior, representado por una serie de normas legales, reglamentarias y administrativas sobre nomenclaturas, valor, tributación aduanera, cuotas compensatorias, regulaciones no arancelarias, regímenes aduaneros especiales, etcétera, necesitan recurrir a expertos como los agentes aduanales.

El capítulo único del título séptimo de la Ley Aduanera vigente regula lo relativo a los agentes aduanales. Asimismo, el capítulo I del título séptimo del Reglamento de la Ley Aduanera vigente desarrolla y pormenoriza las disposiciones de la Ley Aduanera.

Del contenido de las disposiciones de estas dos normativas surgen algunos elementos importantes que debemos analizar respecto de la figura jurídica del agente aduanal, y que señalaremos a continuación.

$\mathrm{Al}$ agente aduanal se le ha caracterizado de diferentes maneras; se ha señalado tanto por parte de la doctrina como por los 
propios criterios del Poder Judicial federal, que son comisionistas, mandatarios, comerciantes, auxiliares de la administración pública, intermediarios entre la administración pública, el comercio y la industria, colaboradores del comercio, entre otras denominaciones.

La propia doctrina ha señalado que existe un déficit de estudios que aborden, de manera sistemática, la naturaleza del agente aduanal. Es por ello que en este capítulo analizaremos algunas de sus características más importantes.

\section{PERSONA FÍSICA}

En este punto queremos destacar dos aspectos. El primero es el relativo a la condición que debe tener el agente aduanal, y es que debe tratarse de una persona física, en oposición a que no puede ser una persona jurídica o moral. El artículo 159 de la Ley Aduanera vigente, precisamente, hace referencia al agente aduanal como "la persona física". El segundo es el relativo a la propia denominación de la figura jurídica de "agente aduanal".

Tradicionalmente se le ha denominado "agente", y el propio Diccionario de la Lengua Española lo define como la "persona que tiene a su cargo una agencia para gestionar asuntos ajenos o prestar determinados servicios".

Aunque su denominación, de acuerdo con la definición del Diccionario de la Lengua Española, es correcta, a veces se le confunde con un servidor público, por lo que, consideramos, sería conveniente pensar en una denominación que lo identifique con su actividad dentro del complejo proceso del comercio internacional.

Por ejemplo, se le denomina despachante de aduanas en Argentina y Paraguay; despachador de aduanas en Chile; agente privado de interés público en Uruguay, y custom broker en Estados Unidos de América. ${ }^{1}$

1 Cisneros García, Juan Rabindrana, Derecho aduanero mexicano, México, Porrúa, 2013, p. 165. 


\section{AUTORIZADO POR EL SERVICIO \\ DE ADMINISTRAGIÓN TRIBUTARIA}

\section{La autorización}

El artículo 159 de la Ley Aduanera señala que el Servicio de Administración Tributaria autorizará a la persona física, mediante una patente, para ejercer como agente aduanal.

De acuerdo con el Diccionario de la Lengua Española, autorizar significa "dar o reconocer a alguien facultad o derecho para hacer algo".

Por su parte, el Segundo Tribunal Colegiado en Materia de Trabajo del Guarto Circuito señaló que:

El acto que realiza la Secretaría de Hacienda y Crédito Público [ahora el Servicio de Administración Tributaria] al otorgar la patente a un agente aduanal no es una concesión federal sino una autorización con características similares a una cédula profesional que le permite realizar, por cuenta propia, sus actividades profesionales y contratar a personal que lleve a cabo la tramitación y gestoría de importación y exportación de mercancías, por lo que su desempeño implica tareas cuya titularidad es ajena a las que correspondan directamente al Estado. ${ }^{2}$

La autorización, como acto administrativo - explica la doctrina-, tiene un doble alcance jurídico: como acto de habilitación o permiso stricto sensu, y como acto de fiscalización o control. ${ }^{3}$

2 Tesis aislada IV.2o.T.54 L, Tribunales Colegiados de Circuito, "COMPETENCIA. TRATÁNDOSE DE CONFLICTOS LABORALES ENTRE UN AGENTE ADUANAL Y SUS TRABAJADORES, SE SURTE EN FAVOR DE LAS JUNTAS LOCALES DE CONCILIACIÓn Y ARBITRAJE", Semanario Judicial de la Federación y su Gaceta, Novena Época, t. XV, enero de 2002, p. 1276.

3 Véase Dromi, Roberto, Derecho administrativo, Buenos Aires, Ciudad Argentina, 2001, p. 309. 
Como acto de habilitación o permisión, la autorización se traduce en aquellas licencias que la autoridad administrativa confiere a los administrados en el ejercicio de la policía administrativa.

Bajo la categoría de autorización, explica José Araujo Juárez, se engloban técnicas muy diversas, en cuanto a su contenido y denominación (autorizaciones, licencias, permisos, habilitaciones, etcétera), que no son sino especies de un mismo género común, cuyo efecto básico consiste en habilitar al particular para que realice una determinada conducta que, de otro modo, resultaría contraria al ordenamiento jurídico, ya que se trata de un medio de control ex ante. ${ }^{4}$

En ese sentido, la Segunda Sala de la Suprema Corte de Justicia de la Nación explica que los agentes aduanales

...llevan a cabo los trámites relacionados con el despacho aduanero y son responsables de la veracidad y exactitud de los datos e información suministrados, de la determinación del régimen aduanero de las mercancías y de su correcta clasificación arancelaria, así como de cerciorarse que el exportador o importador cuente con los documentos que acrediten el cumplimiento de las demás obligaciones en materia de regulaciones y restricciones no arancelarias, además de que ya elaborado el pedimento y efectuado el pago de contribuciones y cuotas compensatorias, se presentarán las mercancías con el pedimento ante la autoridad aduanera y se activará el mecanismo de selección automatizado que determinará si debe practicarse el reconocimiento aduanero de las mercancías, caso en el que, de acuerdo con el indicado artículo 43, la autoridad señalada efectuará el reconocimiento ante quien presente las mercancías en el recinto fiscal, de ahí que es obligación del agente aduanal formular el pedimento y realizar el pago de las contribuciones y cuotas compensatorias. ${ }^{5}$

4 Araujo Juárez, José, Derecho administrativo. Parte general, Caracas, Venezuela, Ediciones Paredes, 2008, p. 538.

5 Tesis de jurisprudencia 2a./J. 131/2009, Segunda Sala, "RECONOCIMIENTO ADUANERO. LA IMPOSIBILIDAD DE REALIZARLO POR NO ENCONTRARSE LAS MERCANCÍAS EN EL LUGAR ESTABLEGIDO PARA TAL EFEGTO ES 
De lo cual se deduce que el concepto "autorizada", utilizado por el legislador, es correcto. Por lo que se considera que lo que resulta necesario actualizar es la denominación del acto por medio del cual se autoriza al agente aduanal, es decir, el de patente, y utilizar otro que sea acorde con la actividad que realiza el agente aduanal, que podría ser el de "permiso" o incluso "autorización”.

\section{Competencia exclusiva del Servicio de Administración Tributaria}

El artículo 19, fracción XIX, del Reglamento Interior del Servicio de Administración Tributaria establece que le corresponde a la Administración General de Aduanas otorgar las patentes de agente aduanal.

\section{MEDiante una PATENTE}

\section{Aspectos generales}

$\mathrm{Al}$ acto administrativo por el cual el agente aduanal puede ejercer el cargo se le denomina "patente".

La patente de agente aduanal, como lo señala la propia Ley Aduanera, es la autorización personal e intransferible que otorga el Servicio de Administración Tributaria a una persona física para promover por cuenta ajena el despacho de mercancías.

Se le ha denominado, tradicionalmente, como patente. Desde la primera normativa que reglamenta la figura del agente aduanal, el Decreto reglamentando los derechos y obligaciones de los agentes aduanales de 1918, se le denominó como patente.

Las leyes posteriores en materia aduanera también le han denominado "patente".

IMPUTABLE A LOS PROPIETARIOS DE LOS MEDIOS DE TRANSPORTE”, Semanario Fudicial de la Federación, Novena Época, t. XXX, septiembre de 2009, p. 676. 
El Pleno de la Suprema Corte de Justicia de la Nación, desde la Séptima Época, se pronunció respecto de este punto. En su momento dijo:

La patente que habilita a los agentes aduanales para el ejercicio de sus actividades, tiene más bien el carácter de un permiso (o licencia) expedido por la Secretaría de Hacienda y Crédito Público, similar a la cédula profesional expedida por la Secretaría de Educación Pública en favor de los diversos profesionistas, que el de una concesión administrativa federal, ya que esta última constituye una autorización expedida por el Estado en favor de particulares, para que éstos realicen una actividad que originariamente corresponde desarrollar al propio Estado, consistente en la explotación de bienes propiedad de la nación (minas, bosques, petróleo, etcétera), o en la prestación de un servicio público de interés colectivo (teléfonos, energía eléctrica, ferrocarriles, etcétera), circunstancias éstas que no se dan en el caso de los agentes aduanales. ${ }^{6}$

En la práctica, y en sentido estricto, se le denomina "patente" al acto administrativo por el cual se habilita a una persona física para ejercer funciones de agente aduanal ante una aduana que la misma autoridad determina, como aduana de adscripción, asignándosele un número a dicha patente.

$\mathrm{Al}$ acto administrativo por medio del cual se habilita al agente aduanal para actuar en una o en más aduanas adicionales a la de su adscripción se le denomina "autorización".

Como señalamos en el punto anterior, consideramos que es mejor, en la actualidad, denominarle "permiso" o "autorización".

Incluso la Primera Sala de la Suprema Corte de Justicia de la Nación señaló que "el Estado otorga a los agentes aduanales

6 Tesis aislada, Pleno, "Agentes aduanales. Patente QUE LOS HABILITA PARA EJERCER. NO TIENE EL GARÁCTER DE UNA CONCESIÓN ADMINISTRATIVA", Semanario fudicial de la Federación, Séptima Época, primera parte, vol. 34, p. 24 . 
la patente respectiva cuya actuación atiende a una actividad que legalmente requiere autorización, en aras de proteger los intereses de la sociedad". ${ }^{7}$

\section{Diferencias con otras figuras jurídicas}

Existen, en el ámbito del derecho administrativo, otras figuras jurídicas mediante las cuales el Estado otorga a los particulares una habilitación para que realicen diferentes actividades que originalmente corresponde desarrollar al propio Estado. Nos referimos al permiso y a la concesión, que explicaremos a continuación.

\section{A. Permiso}

Según el Diccionario de la Lengua Española, la palabra permiso deriva del latín permissum, que significa "licencia o consentimiento para hacer o decir algo".

Olga Hernández Espíndola explica que

...entre los actos administrativos, el permiso es el reconocimiento a cargo de la autoridad competente de un derecho del particular, que allana la vía para el ejercicio de una actividad especial reglamentada por el Estado, o la realización de actos que ensanchan la esfera jurídica de su circunstancia. ${ }^{8}$

Los permisos, explica la Segunda Sala de la Suprema Corte de Justicia de la Nación, "son actos condiciones, porque median-

7 Tesis aislada 1a. II/2007, Primera Sala, "AGENTES ADUANALES. LOS ARTÍCULOS 164, FRACCIÓN IV Y 165, FRACGIÓN III, DE LA LEY ADUANERA, AL PREVER CAUSAS DE SUSPENSIÓN EN SUS FUNCIONES, ASÍ GOMO DE CANCELACIÓN DE LA PATENTE RESPECTIVA, NO TRANSGREDEN EL ARTÍGULO 25 DE LA Constitución federal (LEgislación Vigente En 2002)", Semanario fudicial de la Federación y su Gaceta, Novena Época, t. XXV, enero de 2007, p. 472.

8 Hernández Espíndola, Olga, "Permiso administrativo", Nuevo Diccionario Furídico Mexicano, México, Porrúa-UNAM, 2001, t. P-Z, p. 2839. 
te ellos se faculta a una persona que ha satisfecho determinados requisitos, para que ejecute actos que no puede realizar la generalidad". 9

Así, el permiso administrativo se puede clasificar dentro de los actos jurídicos directamente orientados a ampliar la esfera de derechos y obligaciones de los particulares frente al Estado.

\section{B. Concesión}

El Diccionario de la Lengua Española la define como "el negocio jurídico, por el cual la administración cede a una persona facultades de uso privativo de una pertenencia del dominio público o la gestión de un servicio público en plazo determinado bajo ciertas condiciones".

La concesión, explica Jorge Fernández Ruiz, es una figura jurídica que permite a quien tiene la titularidad de determinadas atribuciones o facultades, o de ciertos bienes o derechos, delegar su ejercicio o aprovechamiento, en favor de un tercero. ${ }^{10}$

Se divide en concesión mercantil y administrativa, refiriéndose a esta última como la relativa a la transferencia a particulares del desempeño de actividades propias de la administración pública, o a la constitución a favor de ellos de derechos o poderes previstos en el ordenamiento jurídico, de los que antes carecían. ${ }^{11}$

Acerca de la concesión administrativa, Andrés Serra Rojas explica que es un procedimiento discrecional eficaz dentro de la estructura de la sociedad moderna, para entregar a los particulares ciertas actividades o la explotación de bienes federales que el Estado no está en condiciones de desarrollar por su incapacidad

9 Tesis aislada, Segunda Sala, "LiCEncias ADMINISTRATIVAS. TrasPaso O CESIÓn DE LAS", Semanario Zudicial de la Federación, Quinta Época, t. XLVI, p. 5359.

10 Fernández Ruiz, Jorge, Derecho administrativo. Servicios públicos, México, Porrúa, 1995, p. 243.

11 Ibidem, p. 245. 
económica, o porque así lo estima útil o conveniente, o se lo impide su propia organización. ${ }^{12}$

Esta concesión administrativa, explica Jorge Fernández Ruiz, puede ser para la prestación de servicios públicos.

Al respecto, Héctor Escola ${ }^{13}$ explica que la finalidad del servicio público se puede concretar en la atención de necesidades de los particulares, individualmente o en su conjunto, asumidas por el Estado que originan prestaciones de interés púbico que sirven al bien común.

Fanny Pineda señala que el servicio público es la

...institución jurídico-administrativa en la que el titular es el Estado y cuya única finalidad consiste en satisfacer de manera regular, continua y uniforme necesidades públicas de carácter esencial, básico o fundamental; se concreta a través de prestaciones individualizadas, las cuales podrán ser suministradas directamente por el Estado o por particulares mediante concesión. ${ }^{14}$

Consideramos que el criterio antes mencionado resulta inapropiado, toda vez que la declaración veraz de los datos que determinan el cumplimiento de las disposiciones legales para la importación o exportación no es una prestación de un servicio público, sino una obligación de los importadores y exportadores; asimismo, el realizar estas declaraciones a través de un agente aduanal no puede considerarse como una prestación que el Estado otorga a los contribuyentes, sino como una prerrogativa que los mismos tienen.

12 Serra Rojas, Andrés, Derecho administrativo, México, Porrúa, 1981, citado por Fernández Ruiz, Jorge, op. cit., p. 245.

13 Escola, Héctor Jorge, Compendio de derecho administrativo, Buenos Aires, Depalma, 1990, pp. 6 y 7, citado por Salgado Ledesma, Eréndira, "Capítulo tercero. Función pública”, en Olivos Campos, José René (coord.), Derecho administrativo, México, Porrúa, 2014, p. 65.

14 Pineda, Fanny, "Servicio público", Diccionario furídico Mexicano, México, Porrúa-UNAM, 2011 , t. P-Z, p. 3453. 
No se está frente al otorgamiento de ningún servicio, sino al cumplimiento de ciertas obligaciones, siendo el agente aduanal la persona con conocimientos suficientes para facilitar a los importadores/exportadores el cumplimiento de estas obligaciones.

De lo anterior se colige que aunque puedan parecer sinónimos, existe una distinción entre permiso y concesión, ya que esta última otorga facultades para explotar bienes pertenecientes al Estado o para otorgar algún servicio público; supuesto en el que no entra la patente aduanal.

\section{Requisitos para obtener la patente}

\section{A. Aspectos generales}

Para poder obtener la patente de agente aduanal, el interesado debe reunir los requisitos establecidos en la legislación aduanera, así como en las convocatorias emitidas por el Servicio de Administración Tributaria.

El artículo 159 de la Ley Aduanera establece los requisitos que se detallan a continuación.

\section{B. Ser mexicano por nacimiento}

El requisito de ser mexicano por nacimiento se ha mantenido vigente - aunque con diversas modificaciones - desde la primera ley que regula a la figura del agente aduanal. Inclusive, estuvo señalado en el artículo 32, párrafo 2, de la Constitución. Este requisito se acredita con el acta de nacimiento.

\section{G. Estar en pleno ejercicio de sus derechos}

Se entiende que estar en pleno ejercicio de los derechos es tener plena capacidad. 
Jurídicamente se entiende como la aptitud legal de una persona para ser sujeto de derechos y obligaciones, o como la facultad o posibilidad de que esta persona pueda ejercitar sus derechos y cumplir sus obligaciones por sí misma.

A la capacidad se le estudia desde dos aspectos diferentes: a) la de goce, y b) la de ejercicio. La capacidad de goce es un atributo de la personalidad (que se adquiere con el nacimiento y se pierde con la muerte) en virtud de la cual una persona puede ser titular de derechos y obligaciones. La capacidad de ejercicio es la aptitud que requieren las personas para ejercitar por sí mismas sus derechos y cumplir sus obligaciones; se adquiere con la mayoría de edad o con la emancipación y se pierde junto con las facultades mentales.

La capacidad de ejercicio para los efectos de los actos jurídicos tiene un doble aspecto: a) capacidad general, referida a aquella aptitud requerida para la realización de cualquier tipo de actos jurídicos, y b) la capacidad especial, como la aptitud requerida a determinadas personas en la realización de actos jurídicos específicos. $^{15}$

\section{No haber sido condenado por sentencia ejecutoriada por delito doloso}

Este requisito se señaló en la Ley Aduanera de 1982, la que establecía no haber sido condenado por delito intencional o por cometer la infracción de contrabando, para quedar como actualmente la encontramos con la reforma publicada en el Diario Oficial de la Federación del 9 de diciembre de 2013. Es necesario cumplir con este requisito, en virtud de que el agente aduanal es, en gran medida, responsable del comercio exterior de nuestro país. ${ }^{16}$

15 González Ruiz, Samuel Antonio, "Capacidad", Diccionario Furídico Mexicano, México, Porrúa-UNAM, 2011, pp. 467 y 468.

16 Véase Carvajal Contreras, Máximo, Derecho aduanero, México, Porrúa, 2000 , p. 397. 
El documento que acredita que una persona no ha sido condenada por sentencia ejecutoriada por delito doloso es la constancia de antecedentes no penales.

La expedición de la constancia permite acreditar si una persona ha sido o no condenada por sentencia firme dictada por los órganos jurisdiccionales competentes.

Se solicita a la Secretaría de Gobernación, a través de la Comisión Nacional de Seguridad, órgano administrativo desconcentrado de prevención y readaptación social.

A nivel estatal, la carta de no antecedentes penales es expedida por las procuradurías de justicia de cada estado.

E. En el caso de haber sido agente o apoderado aduanal, su patente no hubiere sido cancelada o extinguida

Cabe la posibilidad de que la persona que anteriormente hubiera obtenido una patente para ejercer como agente aduanal pueda volver a solicitar una patente, pero la condición que exige la ley es que la forma en la que dejó de ejercer ese derecho no haya sido por la cancelación o la extinción de la patente.

F. No ser servidor público, excepto tratándose de cargos de elección popular, ni militar en servicio activo

Este requisito obedece a razones lógicas, ya que al ser el agente aduanal un enlace entre la administración pública y los particulares, no podría cumplir cabalmente sus funciones si desempeñara un cargo o comisión que fuera incompatible con la profesión, actividad o mandato que le otorguen los particulares para el manejo de las mercancías de comercio exterior. ${ }^{17}$

17 Idem. 
Es menester remarcar que el agente aduanal no es un servidor público ni funge como tal al explotar la patente que le expide el Servicio de Administración Tributaria.

\section{G. No tener parentesco por consanguinidad en línea recta sin limitación de grado y colateral hasta el cuarto grado, ni por afinidad, con el administrador de la aduana de adscripción de la patente}

En la línea recta por consanguinidad no hay límite; en todos los grados está prohibido tener parentesco con el administrador de la aduana de adscripción.

En la línea colateral por consanguinidad, en segundo grado se encuentran los hermanos, en el tercer grado los tíos y los sobrinos, y en el cuarto grado están los tíos abuelos y los sobrinosnietos.

Por afinidad siempre está prohibido. Es decir, con los suegros, con los cuñados, con los abuelos del cónyuge, y con los bisabuelos del cónyuge, etcétera.

Este requisito, según el artículo 160, fracción XI, de la Ley Aduanera, se extiende a los subadministradores de cualquiera de las aduanas en las que ejerza la patente.

En el caso contrario, deberá cesar sus operaciones en la aduana en la que tenga parentesco con los citados servidores públicos mientras continúen en su cargo.

\section{H. Tener título profesional o su equivalente en los términos de la ley de la materia}

Aunque la Ley Aduanera vigente no establece qué títulos son los idóneos para que una persona pueda ejercer como agente aduanal, la Ley Aduanera de 1981 sí señalaba en el artículo 143, fracción VI, que para obtener la patente de agente aduanal se 
requería tener título profesional "en las siguientes ramas: Licenciado en Derecho, Licenciado en Economía, Licenciado en Administración de Empresas, Contador Público, vista aduanal, [u] otras ramas profesionales que aseguren el eficaz ejercicio de la patente y que señale el reglamento".

\section{Tener experiencia en materia aduanera, mayor de cinco años}

La inclusión de este requisito tiene como finalidad que el interesado esté interiorizado en la problemática del comercio internacional.

Este requisito resulta de la mayor relevancia, en virtud de que, precisamente, la figura del agente aduanal surgió para acreditar a especialistas en esta materia y que se cometa el menor número de errores al momento de realizar el despacho de las mercancías.

\section{J. Estar inscrito en el Registro Federal de Contribuyentes, y demostrar estar al corriente en el cumplimiento de sus obligaciones fiscales}

El requisito de estar inscrito en el Registro Federal de Contribuyentes es indispensable para que el agente pueda prestar sus servicios profesionales, en virtud de que la propia actividad así lo requiere. No se podría imaginar un agente aduanal que no esté inscrito en el Registro Federal de Contribuyentes y que no cuente con las herramientas tecnológicas necesarias para realizar sus actividades.

El requisito consistente en demostrar estar al corriente de las obligaciones fiscales también se encuentra establecido para que el agente aduanal pueda operar, y está señalado en el artículo 160, fracción I, de la Ley Aduanera.

El artículo 215 del Reglamento de la Ley Aduanera establece que el documento que acredita que el agente aduanal está al corriente de sus obligaciones fiscales es la constancia de cumpli- 
miento de las obligaciones fiscales referida en el último párrafo del artículo 32-D del Código Fiscal de la Federación.

\section{K. Aprobar el examen de conocimientos que practique la autoridad aduanera y un examen psicotécnico}

La finalidad es que los agentes aduanales demuestren que poseen los conocimientos y las habilidades necesarios para realizar las actividades que les imponen las normas en materia aduanera y de comercio exterior.

El artículo 216 del Reglamento de la Ley Aduanera establece que "el examen psicotécnico... constará de dos etapas, la de confiabilidad y la psicológica, y serán practicadas por la autoridad competente conforme al Reglamento Interior del SAT”.

El Reglamento Interior del Servicio de Administración Tributaria señala en el artículo 19, fracción XX, que le corresponde a la Administración General de Aduanas

...diseñar, aplicar y evaluar los exámenes de conocimientos y psicotécnicos para obtener las patentes de agente aduanal y las autorizaciones de mandatario de agente aduanal y de dictaminador aduanero, así como emitir la convocatoria para que los agentes aduanales puedan someterse a dichos exámenes y los lineamientos que deberán cumplir las instituciones académicas o especializadas en evaluación para la aplicación de los referidos exámenes a los agentes aduanales y acreditar a dichas instituciones.

\section{Cumplir con los lineamientos indicados en la Convocatoria}

La Convocatoria se deberá efectuar cuando menos cada dos años ${ }^{18}$ y deberá publicarse en el Diario Oficial de la Federación. ${ }^{19}$

18 Artículo 212 del Reglamento de la Ley Aduanera.

19 Artículo 159, segundo párrafo, de la Ley Aduanera. 
Aunque cabe señalar que no se ha publicado alguna convocatoria en términos de la última reforma a la Ley.

Si bien es cierto que la ley anterior no señalaba de manera expresa la publicación de una convocatoria, la autoridad sí otorgaba las patentes mediante una convocatoria que se publicaba en el Diario Oficial de la Federación. La última que apareció en el Diario Oficial fue la del 8 de febrero de 1994.

\section{Procedimiento}

\section{A. Convocatoria}

Tanto la Ley Aduanera como su Reglamento establecen las etapas y los plazos para que las personas interesadas puedan obtener una patente de agente aduanal.

La patente se puede obtener por medio de un concurso público a través de una convocatoria.

La convocatoria se debe expedir cuando menos cada dos años, aunque - como se ha señalado - la última convocatoria que se publicó en el Diario Oficia de la Federación fue el 8 de febrero de 1994, es decir, bajo la vigencia de la anterior Ley Aduanera.

Según dicha convocatoria, los interesados debían entregar un escrito libre, dirigido al ciudadano administrador general de aduanas, en el que indicaran su nombre completo, domicilio y teléfono para recibir notificaciones en su localidad, y la aduana de adscripción en la que solicitaban operar.

El artículo 159, último párrafo, de la Ley Aduanera señala que una vez cubiertos los requisitos que señalan la ley, el reglamento y la convocatoria respectiva, la Secretaría otorgará la patente en un plazo que no deberá exceder de cuatro meses.

\section{B. Publicación en el Diario Oficial de la Federación}

El artículo 214 del Reglamento de la Ley Aduanera establece que "el acuerdo por el que el Servicio de Administración Tribu- 
taria otorgue una patente de agente aduanal se publicará en el Diario Oficial de la Federación por una sola vez a costa del titular de la patente respectiva, quien previamente deberá cubrir los derechos que correspondan".

Los agentes aduanales deberán registrar su patente ante la aduana de adscripción a partir de la publicación a que se refiere el párrafo anterior.

Asimismo, el Servicio de Administración Tributaria notificará el acuerdo de otorgamiento de la patente a los administradores de las aduanas respectivas.

\section{Requisitos para operar}

El artículo 159 de la Ley Aduanera señala los requisitos que se deben cubrir para obtener una patente para ejercer como agente aduanal. Por su parte, el artículo 160 de la Ley Aduanera señala los requisitos que deben cumplir para operar, es decir, para que puedan comenzar a prestar sus servicios profesionales a los importadores y exportadores.

El artículo 160 establece que "el agente aduanal deberá cubrir los siguientes requisitos para operar":

I. Estar al corriente en el cumplimiento de sus obligaciones fiscales.

Este requisito se acredita con la constancia de cumplimiento de las obligaciones fiscales referida en el último párrafo del artículo 32-D del Código Fiscal de la Federación. ${ }^{20}$

II. Transmitir al sistema electrónico aduanero en la forma y periodicidad que el Servicio de Administración Tributaria determine en reglas, la información estadística de los pedimentos.

III. Residir en el territorio nacional, y mantener la oficina principal de sus negocios en el lugar de la aduana de adscripción para la atención de los asuntos propios de su actividad.

20 Reglamento de la Ley Aduanera, artículo 215. 
La residencia en territorio nacional se acredita mediante constancia de residencia que expida el municipio o circunscripción territorial en que resida el agente aduanal. ${ }^{21}$

IV. Manifestar a las autoridades aduaneras el domicilio de su oficina para oír y recibir notificaciones en la circunscripción de las aduanas en las que ejerza la patente. Las que se realicen en ese lugar surtirán sus efectos en los términos legales; así mismo, dar aviso a las mismas del cambio de domicilio, aun en el caso de suspensión voluntaria de actividades.

El domicilio fiscal es aquel que se haya declarado para efectos del Registro Federal de Contribuyentes. ${ }^{22}$

Cuando el agente aduanal no haya dado aviso correspondiente del cambio de su domicilio, las autoridades aduaneras podrán seguir practicando las notificaciones en el domicilio manifestado. $^{23}$

V. Ocuparse personal y habitualmente de las actividades propias de su función y no suspenderlas en caso alguno, excepto cuando lo ordene el Servicio de Administración Tributaria o cuando haya obtenido la autorización a que se refiere el siguiente párrafo.

VI. Dar a conocer a la aduana en que actúe, los nombres de los empleados o dependientes autorizados para auxiliarlo en los trámites de todos los actos del despacho, así como los nombres de los mandatarios que lo representen al promover y tramitar el despacho. El agente aduanal será ilimitadamente responsable por los actos de sus empleados o dependientes autorizados y de sus mandatarios.

VII. Realizar los actos que le correspondan conforme a esta Ley en el despacho de las mercancías, empleando el sistema electrónico y la firma electrónica avanzada que le asigne el Servicio de Administración Tributaria.

VIII. Contar con el equipo necesario para promover el despacho electrónico, conforme a las reglas que emita la Secretaría y utilizarlo en las actividades propias de su función.

21 Ibidem, artículo 217.

22 Ibidem, artículo 231.

23 Ibidem, artículo 213. 
IX. Ocuparse, en su aduana de adscripción, por lo menos, del $15 \%$ de las operaciones de importación y exportación con valor que no rebase al que, mediante reglas, determine el Servicio de Administración Tributaria.

X. Utilizar los candados oficiales o electrónicos en los vehículos y contenedores que transporten las mercancías cuyo despacho promueva, de conformidad con lo que establezca el Servicio de Administración Tributaria mediante reglas, así como evitar que los candados fiscales que adquiera de los importadores o fabricantes autorizados, se utilicen en contenedores o vehículos que transporten mercancías cuyo despacho no hubiere promovido.

\section{Efectos de la patente}

La patente de agente aduanal es personal e intransferible.

...le da derecho al titular para actuar ante una aduana de adscripción; sin embargo, el agente aduanal podrá solicitar autorización al Servicio de Administración Tributaria para actuar en una aduana adicional a la de adscripción por la que se le otorgó la patente. Las autoridades aduaneras deberán otorgar la autorización en un plazo no mayor de dos meses, siempre que el agente aduanal demuestre que se encuentra al corriente en el cumplimiento de sus obligaciones fiscales.

En ningún caso se podrá autorizar a un agente aduanal para efectuar despachos en más de tres aduanas adicionales a la de su adscripción. Cuando el agente aduanal expresamente renuncie a una aduana que le hubiera sido autorizada conforme al párrafo anterior de este artículo, podrá presentar solicitud para que se le autorice actuar en otra aduana. ${ }^{24}$

24 Artículo 161 de la Ley Aduanera vigente. 


\section{PARA PROMOVER POR GUENTA AJENA EL DESPACHO \\ DE LAS MERGANCÍAS, EN LOS DIFERENTES REGÍMENES ADUANEROS PREVISTOS EN LA LEY}

\section{Aspectos generales}

La naturaleza del agente ha ido cambiando a lo largo de la historia, esto en atención a las diversas reformas que han sufrido las normas reguladoras de esta actividad y al aumento de las actividades que se realizan dentro del comercio internacional.

La Ley establece, en diferentes artículos, que el agente aduanal actuará, dependiendo de la actividad que realice, como mandatario, consignatario o representante legal.

Al respecto, el Primer Tribunal Colegiado en Materias Administrativa y Civil del Décimo Noveno Circuito determinó que: "...la persona física que hubiese obtenido la patente de agente aduanal, únicamente está facultada para gestionar en nombre de terceros el despacho de mercancías en materia de importación y exportación, previsto en el Ley Aduanera". ${ }^{25}$

Con las reformas de 2013 se genera confusión respecto a cuál es la naturaleza del agente aduanal, en virtud de que la legislación aduanera es omisa en señalar con precisión cuál es esa naturaleza con la que el agente se ostenta, pues solamente se limita a señalarlo como consignatario, mandatario y representante legal, en términos de lo dispuesto en el artículo 41 de la Ley Aduanera.

25 Tesis aislada XIX.1o.A.C.35 A, Primer Tribunal Colegiado en Materias Administrativa y Civil del Décimo Noveno Circuito, "AgEnTE AduAnaL. SU RESPONSABILIDAD SOLIDARIA NO SE LIMITA A LA CONCLUSIÓN DEL DESPACHO ADUANERO, SINO QUE ESTÁ SUJETA AL ALCANCE DE SU ACTUACIÓN", Semanario fudicial de la Federación y su Gaceta, Novena Época, t. XXVII, abril de 2008, p. 2287. 


\section{Consignatario}

Es la acción y efecto de consignar, ya sea al entregar por vía de depósito un bien, al enviar mercaderías a manos de un destinatario, o bien al depositar judicialmente cierta cantidad monetaria. ${ }^{26}$

El motivo por el cual la Ley los incorpora y les otorga ese carácter es para que los agentes aduanales puedan acceder a la mercancía y llevar a cabo el despacho aduanero. Esa es la razón de otorgarles dicho carácter.

El agente aduanal, en su calidad de consignatario, puede liberar la guía y el conocimiento de embarque.

\section{Mandatario}

Del latín mandatum, que, como ya se mencionó, es el contrato por el cual una persona llamada mandatario se obliga a ejecutar por cuenta de otra, denominada mandante, los actos jurídicos que éste le encarga.

El mandato puede ser con o sin representación. Comúnmente es oneroso. Puede ser para actos jurídicos en específico o puede ser un mandato general. El mandato es un contrato fundado en la confianza; por eso, aunque el mandato es un contrato principal y oneroso, salvo que se pacte expresamente su gratuidad, es unilateral, en virtud de que el mandante puede revocar el mandato, y el mandatario, por su parte, puede renunciar al mismo. ${ }^{27}$

De lo anterior se desprende que la naturaleza jurídica del agente aduanal reviste, en el fondo, la naturaleza jurídica de un

26 Véase "Consignación", Nuevo Diccionario Furídico Mexicano, México, Porrúa-UNAM, t. A-C, p. 785.

27 Véase "Mandato", Nuevo Diccionario Furídico Mexicano, México, PorrúaUNAM, 2001, t. I-O, pp. 2454 y 2455. 
mandatario. ${ }^{28}$ Sin embargo, puede considerarse que, de todas estas denominaciones, sobresale su actuación como mandatario, siendo el mandato un contrato mediante el cual el mandatario se obliga a ejecutar por cuenta del mandante los actos jurídicos que éste le encarga. ${ }^{29}$

\section{Representante legal}

La representación, explica Miguel Soberón Mainero, es el acto de representar o la situación de ser representado.

Sustituir a otro o hacer sus veces. La representación, en sentido general, es un fenómeno jurídico que implica la actuación a nombre de otro, en el campo del derecho. La representación supone, pues, que una persona que no es a quien corresponden los intereses jurídicos en juego, ponga su propia actividad, su "querer", al servicio de tales intereses ajenos, realizando un acto jurídico a nombre de la persona a quien pertenecen. ${ }^{30}$

De acuerdo con lo establecido en el artículo 41 de la Ley Aduanera, el agente aduanal actuará como representante legal:

I. Tratándose de las actuaciones que deriven del despacho aduanero de las mercancías, siempre que se celebren dentro del recinto fiscal.

II. Tratándose de las notificaciones que deriven del despacho aduanero de las mercancías.

III. Cuando se trate del acta o del escrito a que se refieren los artículos 150 y 152 de esta Ley.

28 Trejo Vargas, Pedro, El sistema aduanero de México, México, Servicio de Administración Tributaria, 2003, p. 440.

29 Artículo 2546 del Código Civil Federal.

30 Soberón Mainero, Miguel, "Representación”, Diccionario furídico Mexicano, México, Porrúa-UNAM, 201 1, t. P-Z, pp. 3317 y 3318. 
IV. Tratándose de las actuaciones y notificaciones que deriven de la inspección o verificación de las mercancías, durante su permanencia en el recinto fiscal por virtud de su despacho.

$\mathrm{Al}$ respecto, debemos destacar que los agentes aduanales son profesionales que cuentan con el conocimiento de las normas y procedimientos aduaneros, pues de lo contrario la autoridad no les expediría la patente para operar como tales.

La obligatoriedad de comparecer ante las aduanas a través de agentes aduanales se estableció en diferentes leyes anteriores a la vigente, precisamente atendiendo al desconocimiento de los importadores y exportadores de las normas y trámites aduaneros, y a la imperiosa necesidad de seguridad y rapidez del desaduanamiento de sus mercancías. ${ }^{31}$

La Segunda Sala de la Suprema Corte de Justicia de la Nación señala que "la representación que la ley otorga a los agentes aduanales para actuar a nombre del importador, se limita a la realización de los trámites administrativos relativos a la entrada de mercancías al territorio nacional" ${ }^{32}$

...en términos del numeral 41 de la citada ley, la representación otorgada a los agentes aduanales para actuar en nombre del importador se limita a la realización ante las autoridades aduanales, de los trámites administrativos y de aquellos relacionados con el desahogo de las diferencias legales o fácticas que surjan entre la

31 Trejo Vargas, Pedro, El sistema aduanero de México, cit., p. 439.

32 Tesis de jurisprudencia 2a./J.175/2004, Segunda Sala, Semanario Judicial de la Federación y su Gaceta, Novena Época, t. XX, diciembre de 2004, p. 385. Por su parte, el Décimo Tercer Tribunal Colegiado en Materia Administrativa del Primer Circuito, en una tesis aislada, señaló que "de una interpretación sistemática de los artículos 41, 159 y 161 de la Ley Aduanera se desprende que la persona física que hubiese obtenido la patente de agente aduanal, únicamente está facultada para gestionar en nombre de terceros el despacho de mercancías en materia de importación y exportación". Véase tesis aislada I.13o.A.78 A, Tercer Tribunal Colegiado en Materia Administrativa del Primer Circuito, $\mathrm{Se}$ manario Judicial de la Federación y su Gaceta, Novena Época, t. XX, p. 1279. 
autoridad y el importador o su representante, relativos a la entrada de mercancías al territorio nacional; luego, las notificaciones que se refieran a observaciones por el incumplimiento u omisión de las formalidades relativas al despacho aduanero de mercancías o del acta levantada con motivo de alguna irregularidad detectada en el reconocimiento aduanero en el caso de mercancías que no son de difícil identificación, deberán entenderse con el agente aduanal, en tanto que cualquier error o vicio que en tal aspecto se advierta únicamente repercute en el ámbito de su actuación y representación dentro del aludido despacho, sin afectar los intereses del importador, y atendiendo al párrafo final del dispositivo legal citado en último término, las autoridades aduaneras únicamente tienen obligación de notificar a los importadores y exportadores, además de a su representante - agente aduanal-, de cualquier procedimiento que se inicie con posterioridad al despacho aduanero de manera independiente y autónoma, pues en tal caso ya no existe la representación legal del agente y sí una responsabilidad solidaria en su actuar. ${ }^{33}$

De ahí que, señala la Segunda Sala de la Suprema Corte de Justicia de la Nación:

Si en términos del artículo 41 de la Ley Aduanera el agente aduanal asume el carácter de representante legal del importador o exportador tratándose de: a) las actuaciones derivadas del despacho aduanero siempre que se celebren dentro del recinto fiscal; b) las notificaciones derivadas del despacho aduanero de mercancías, es decir, aquellas que se refieren a los trámites administrativos inherentes a las formalidades relativas a la entrada o salida de

33 Tesis aislada, Tribunales Colegiados de Circuito, "AGEnTES ADUANALES. COMO REPRESENTANTES DEL IMPORTADOR LES GORRESPONDE ATENDER LAS NOTIFICACIONES DERIVADAS DE OBSERVACIONES POR EL INCUMPLIMIENTO U OMISIÓN DE LAS FORMALIDADES RELATIVAS AL DESPACHO ADUANERO DE MERCANCÍAS O DEL ACTA LEVANTADA CON MOTIVO DE LAS IRREGULARIDADES DETECTADAS EN ÉL, YA QUE GUALQUIER ERROR O VICIO QUE EN TAL ASPECTO SE ADVIERTA ÚNICAMENTE REPERCUTE EN EL ÁMBITO DE SU ACTUACIÓN, SIN AFECTAR LOS INTERESES DE AQUÉL", Semanario Fudicial de la Federación, Novena Época, t. XXVI, agosto de 2007, p. 1537. 
mercancías al territorio nacional; c) el acta de inicio del procedimiento administrativo en materia aduanera, cuando con motivo del reconocimiento aduanero, segundo reconocimiento, verificación de mercancías en transporte o por el ejercicio de facultades de comprobación se embarguen precautoriamente mercancías, en términos del artículo 150 de la Ley citada; y, d) el escrito por el que la autoridad aduanera haga del conocimiento del interesado los hechos u omisiones que impliquen la omisión de contribuciones a que se refiere el artículo 152 de la propia Ley, es evidente que la notificación de la resolución por la que se le impone una multa por el indebido cumplimiento u omisión de las formalidades relativas al despacho aduanero de mercancías deberá entenderse sólo con el agente aduanal, en tanto que cualquier error o vicio que en tal aspecto se advierta únicamente repercute en el ámbito de su actuación y representación, sin afectar los intereses del importador o exportador, ya que la obligación de notificar tanto al agente aduanal como al importador o exportador sólo existe al inicio de cualquier procedimiento posterior al despacho aduanero, y porque a la única persona a quien agravia el acta circunstanciada de hechos, donde se dan a conocer las irregularidades referidas, es al agente aduanal, pues a partir de la práctica del reconocimiento de la mercancía correspondiente al pedimento que éste elabora, en la que se detectan clasificaciones arancelarias erróneas, es cuando la autoridad correspondiente determina imponerle una multa, no al importador o exportador, de tal suerte que si no se afecta la esfera jurídica de estos últimos, es innecesario que se les notifique el acta de irregularidades. ${ }^{34}$

La tesis transcrita contiene la interpretación de la Suprema Corte de Justicia de la Nación al artículo 41 de la Ley Aduanera antes de que fuera reformada en 2013, lo cual ha propiciado que exista una nueva interpretación por parte de las autoridades.

Lo anterior significa que en la actualidad sólo se le notifica al agente aduanal y no al importador o exportador, lo cual cambia por completo el criterio antes citado.

34 Tesis de jurisprudencia 2a./J.208/2007, Segunda Sala, Semanario Fudicial de la Federación, Novena Época, t. XXVI, noviembre de 2007, p. 189. 
Cabe destacar que el agente aduanal tiene la obligación de dar a conocer a la aduana en que actúe, los nombres de los empleados o dependientes autorizados para auxiliarlo en los trámites de todos los actos del despacho, así como los nombres de los mandatarios que lo representen al promover y tramitar el despacho.

En ese sentido, el agente aduanal es ilimitadamente responsable por los actos de sus empleados o dependientes autorizados, y de sus mandatarios. ${ }^{35}$

Según lo dispuesto en el artículo 218 del Reglamento de la Ley Aduanera, el agente aduanal deberá designar a un mandatario aduanal sólo en aquellos casos en que las necesidades de sus servicios lo requieran.

Los actos que practiquen los mandatarios aduanales con motivo del despacho y reconocimiento aduanero, así como los actos que deriven de aquéllos, serán imputables al agente aduanal.

Asimismo, el agente aduanal deberá acreditar ante la autoridad aduanera por lo menos a un mandatario por aduana, sin perjuicio de que uno de ellos podrá actuar indistintamente en cualquiera de las aduanas que aquél tenga autorizadas.

\section{Responsable solidario}

El artículo 53 de la Ley Aduanera establece que los agentes aduanales y sus mandatarios autorizados son responsables solidarios del pago de los impuestos al comercio exterior y de las demás contribuciones, así como de las cuotas compensatorias que

35 El artículo 160, fracción VI, de la Ley Aduanera establece que "para ser mandatario aduanal autorizado de agente aduanal se requiere contar con poder notarial y demostrar experiencia aduanera mayor a tres años, aprobar el examen y cumplir los demás requisitos que determine el Servicio de Administración Tributaria mediante reglas. Cada mandatario aduanal promoverá solamente el despacho en representación de un agente aduanal y ante una sola aduana, salvo uno de los mandatarios, que podrá actuar indistintamente en cualquiera de las aduanas autorizadas". 
causen con motivo de la introducción de mercancías al territorio nacional o de su extracción del mismo, y por los que se originen con motivo de las importaciones o exportaciones en cuyo despacho aduanero intervengan personalmente o por conducto de sus empleados autorizados.

$\mathrm{Al}$ respecto, el Pleno del Vigésimo Séptimo Circuito ha senalado que:

La responsabilidad solidaria tiene como característica que el obligado indirecto coincide con una situación prevista por el legislador para cumplir con un deber no tanto de contribuir, sino de garantizar, en su más amplia acepción, el pago de una deuda tributaria, esto es, se ubica en el supuesto establecido por la ley para ser responsable, y tal situación no tiene que ver con la realización objetiva y directa del hecho generador del tributo, ya que sólo responde por situaciones particulares y de exigirse la comprobación de que aquél incumplió con la obligación principal, se le estaría otorgando condición de contribuyente u obligado principal. Ahora bien, si el artículo 53, fracción III, de la Ley Aduanera, prevé la responsabilidad solidaria del pago de los impuestos al comercio exterior y de las demás contribuciones, así como de las cuotas compensatorias causadas con motivo de la introducción de mercancías al territorio nacional, sin perjuicio de lo establecido por el Código Fiscal de la Federación, para los propietarios de medios de transporte por los que causen las mercancías que transporten, cuando no cumplan las obligaciones impuestas en las leyes a que se refiere el artículo 1o. de la invocada legislación aduanera con motivo de la entrada de mercancías extranjeras al país, o tratándose del tránsito de éstas, cuando no cuenten con la documentación que acredite la legal estancia en el país de las que transporten, es inconcuso, que para que se actualice la responsabilidad solidaria en materia aduanera de los propietarios de vehículos particulares, es innecesario demostrar que éstos tuvieron intervención directa en la introducción, extracción, custodia, almacenaje, manejo y tenencia de las mercancías extranjeras, pues ello desvirtuaría la figura jurídica de la responsabilidad solidaria, que parte de la base de ser indirecta y derivada de la omisión de 
un deber, sino que basta que el propietario del vehículo particular, aunque no fuera quien directamente introdujo las mercancías, omita cumplir las obligaciones que con tal carácter le imponen las disposiciones legales para el transporte de mercancías extranjeras y no se acreditara la legal estancia de las transportadas en dicho vehículo. ${ }^{36}$

\section{DERECHOS DEL AGENTE ADUANAL}

La Ley Aduanera vigente establece una serie de derechos a favor del agente aduanal. El artículo 163 de dicha Ley señala que "son derechos del agente aduanal" los siguientes:

\section{Ejercer la patente}

Según el Diccionario de la Lengua Española, la palabra "ejercer" significa "practicar los actos propios de un oficio, facultad o profesión". Es decir que el agente aduanal tiene además la obligación de realizar las actividades que le imponen las leyes y demás normativas. Puede, eventualmente, suspender sus actividades, dando el aviso respectivo, pero invariablemente debe atender a las personas que soliciten sus servicios y los de su agencia aduanal.

\section{Constituir sociedades}

La Ley Aduanera señala, como uno de los derechos del agente aduanal, el de "constituir sociedades integradas por mexicanos para facilitar la prestación de sus servicios. La sociedad y sus socios, salvo los propios agentes aduanales, no adquirirán derecho

36 Tesis de jurisprudencia PC.XXVII. J/1 A (10a.), Pleno del Vigésimo Séptimo Circuito, Gaceta del Semanario Fudicial de la Federación, Décima Época, libro 2, enero de 2014, t. III, p. 2505. 
alguno sobre la patente, ni disfrutarán de los que la ley confiere a estos últimos".

Líneas abajo explicamos cómo se constituye una sociedad para la prestación de servicios aduaneros. Comúnmente se le denomina "agencia aduanal", aunque se trata de empresas que tienen como uno de sus socios al agente aduanal.

3. Solicitar el cambio de adscripción a aduana distinta, siempre que la autorización que se le hubiera otorgado para actuar en su aduana de adscripción tenga una antigüedad mayor a dos años, y compruebe haber concluido el trámite de los despachos iniciados

La patente que se le otorga al agente aduanal lo autoriza para actuar en una aduana determinada, pero si el agente aduanal desea actuar en una aduana adicional debe obtener la autorización respectiva ante la autoridad correspondiente.

Respecto al derecho que le otorga este numeral, el agente aduanal puede solicitar el cambio de adscripción de aduana, pero las condiciones son que la autorización tenga una antigüedad mayor a dos años y que compruebe que los trámites de despacho que haya iniciado se hubieran concluido. No será necesario comprobar la conclusión de los despachos iniciados cuando al agente aduanal le sea autorizada la aduana de adscripción como adicional.

\section{Designar hasta cinco mandatarios}

Los mandatarios son las personas que el agente aduanal designa para que realicen algunas de sus responsabilidades. Como lo señala la Ley, puede designar hasta cinco.

$\mathrm{Al}$ respecto, el Cuarto Tribunal Colegiado en Materia Administrativa del Primer Circuito señaló que: 
Si una patente de agente aduanal condiciona a su titular a sujetarse a las prevenciones que establezcan la Ley Aduanera y su reglamento, los poderes que otorgue a otras personas para que se desempeñen como sus mandatarios, atento al principio que reza que lo accesorio sigue la suerte de lo principal, sujetan a éstos a tales prevenciones. Así, los mandatarios de un agente aduanal al aceptar el poder adquieren también la condición de sujetarse a las prevenciones de dicha normativa, de tal suerte que su derecho es únicamente precario o debilitado, el cual debe entenderse como la figura subjetiva cuya eficacia y vigencia se adapta y acomoda a las necesidades colectivas imperantes en diferentes condiciones de tiempo y lugar, el que puede estar sujeto a mayores requisitos para su ejercicio por razones de oportunidad o interés público sin derecho a exigir su subsistencia en las condiciones iniciales como si se tratara de un derecho adquirido. ${ }^{37}$

\section{Cobrar los honorarios que pacte con su cliente por los servicios} prestados, incluso en el caso a que se refiere el segundo párrafo de la fracción XIV del artículo 144 de la Ley

El agente aduanal tiene el derecho de cobrar sus honorarios, directamente o a través de la agencia aduanal, y puede pactarlos libremente con el importador o exportador.

\section{Suspender voluntariamente sus actividades, previa autorización de las autoridades aduaneras}

La fracción V del artículo 160 de la Ley Aduanera señala que "las autoridades aduaneras podrán autorizar la suspensión voluntaria de actividades de un agente aduanal, previa solicitud que éste presente por escrito y en la que señale las causas que

37 Tesis aislada I.4o.A.526 A, Cuarto Tribunal Colegiado en Materia Administrativa del Primer Circuito, Semanario fudicial de la Federación y su Gaceta, Novena Época, t. XXIV, agosto de 2006, p. 2175. 
justifiquen la suspensión. El agente aduanal podrá reanudar sus actividades en cualquier momento, para lo cual deberá presentar el aviso correspondiente por escrito".

De acuerdo con dicho numeral, ${ }^{38}$ el agente aduanal puede suspender sus actividades; para ello debe solicitar, por escrito, la suspensión a la autoridad competente. En el escrito debe justificar las causas de la suspensión.

La autoridad competente deberá, en caso de que proceda, autorizar la suspensión de actividades del agente aduanal.

El agente aduanal, en el momento que lo considere, puede reanudar sus actividades, para lo cual deberá informarlo, por escrito, a la autoridad competente.

38 Artículo 160, fracción V, de la Ley Aduanera. 


\section{Capítulo Segundo \\ LA AGENCIA ADUANAL}

\section{INTRODUCGIÓN}

En México, la Ley Aduanera únicamente regula lo relativo a los agentes aduanales, pero es omisa en la regulación de las agencias aduanales, a pesar de ser estas últimas las que concentran las actividades de los agentes aduanales, de sus socios y de sus dependientes.

Como bien lo señala Soyla H. León Tovar, "la mayoría de las legislaciones que se ocupan de regular al contrato de agencia no lo definen; en su lugar, se ocupan del agente mismo". 39

Consideramos importante incluir un capítulo en la Ley Aduanera respecto de la figura de la agencia aduanal, como se hace en Chile y en Colombia, por ejemplo, que son las dos legislaciones que hemos tomado como referencia para realizar nuestro análisis en este capítulo.

Cabe señalar que hemos efectuado una búsqueda exhaustiva en la bibliografía y no hemos encontrado referentes en este tema, por lo que las legislaciones de estos países nos servirán de referencia. No se trata, en efecto, de legislaciones más o menos avanzadas en el tema, pero sí con una regulación expresa, que incluso puede servir como guía temática para el legislador si es que se decidiera por incorporar un capítulo, como lo proponemos, en la Ley Aduanera.

39 León Tovar, Soyla H., "La agencia mercantil", Boletín Mexicano de Derecho Comparado, México, núm. 68, mayo-agosto de 1990, p. 520. 
La creación de la "agencia aduanal", en la práctica, se realiza con base en la legislación civil y mercantil; sin embargo, algunas de las actividades que se llevan a cabo por las personas que trabajan en la agencia son consideradas como si las realizara el agente aduanal, situación que analizamos en este capítulo.

El artículo 163, fracción II, de la Ley Aduanera vigente establece que los agentes aduanales podrán constituir sociedades integradas por mexicanos para facilitar la prestación de sus servicios. La sociedad y sus socios, salvo los propios agentes aduanales, señala la Ley, no adquirirán derecho alguno sobre la patente ni disfrutarán de los que la ley confiere a estos últimos.

Estas empresas de servicios aduanales son propiedad de los agentes aduanales y de sus socios, y si bien sirven de apoyo a la gestión fundamental de sus dueños y accionistas, la responsabilidad absoluta del despacho recae en la persona física que ha recibido la patente. ${ }^{40}$

\section{CONSTitución DE LA AGENGiA ADUANAL}

La agencia aduanal es la persona moral constituida conforme a las leyes civiles o mercantiles. Regularmente se constituye como una empresa bajo la denominación de una "sociedad civil", aunque la Ley Aduanera no establece cuál debería ser la forma idónea para su constitución. Es decir que una agencia aduanal puede integrarse con varios socios, dentro de los cuales se incluye el agente aduanal, quien es el responsable del cumplimiento de las responsabilidades de la patente aduanal y, por tanto, de muchas de las que realiza la propia agencia aduanal.

En Colombia, el artículo 12 del Decreto 2883 señala que:

Las agencias de aduanas son las personas jurídicas autorizadas por la Dirección de Impuestos y Aduanas Nacionales para ejercer el agenciamiento aduanero, actividad auxiliar de la función pú-

40 Reyes Díaz-Leal, Eduardo, El despacho aduanal, México, 2003, p. 97. 
blica aduanera de naturaleza mercantil y de servicio, orientada a garantizar que los usuarios de comercio exterior que utilicen sus servicios cumplan con las normas legales existentes en materia de importación, exportación y tránsito aduanero y cualquier operación o procedimiento aduanero inherente a dichas actividades.

En Chile, la Ordenanza de Aduanas, en su artículo 198, establece que "con el objeto de explotar los servicios inherentes al despacho de mercancías, los agentes de aduana podrán asociarse con otros agentes de aduana o con personas naturales y formar con ellas únicamente sociedades colectivas y de responsabilidad limitada, pero sin que la compañía pueda actuar como agente ante la aduana".

Aunque el artículo 240 de la Ordenanza de Aduanas de Chile, vigente en 1959, señalaba que:

Sólo podrán ser agentes generales, especiales de aduana o de cabotaje las personas naturales.

No obstante, los agentes generales podrán, previa autorización de la Junta General del ramo, formar sociedades colectivas, en comandita, o de responsabilidad limitada, que tengan por objeto la ampliación y explotación de los servicios de despacho para la importación, exportación u otras operaciones relacionadas con estas destinaciones aduaneras, pero sin que la sociedad pueda actuar como tal ante la aduana.

Para estos efectos, la escritura social deberá ser sometida a la aprobación de la Junta General de Aduanas.

Es decir, según los precedentes de la Junta General de Aduanas, "no es procedente la formación de una sociedad entre agentes generales de aduanas, y menos cuando mediante ella se establece de hecho un monopolio de los servicios de despacho, lo que es incompatible con el carácter público que revisten sus funciones". ${ }^{41}$

41 Valenzuela Iglesias, Enrique, Ordenanza de Aduanas de la República de Chile, 3a. ed., Valparaíso, Chile, Imprenta y Litográfica Universo, 1959, p. 506. 
En nuestro país, como lo señalamos antes, el artículo 163, fracción II, de la Ley Aduanera señala que son derechos del agente aduanal: "constituir sociedades integradas por mexicanos para facilitar la prestación de sus servicios. La sociedad y sus socios, salvo los propios agentes aduanales, no adquirirán derecho alguno sobre la patente, ni disfrutarán de los que la ley confiere a estos últimos".

La Ley no establece límite para la constitución de la agencia, en cuanto al número de agentes que pueden integrarla.

En relación con las empresas o agencias aduanales en las que puede ser socio, el artículo 222 del Reglamento de la Ley Aduanera señala que los agentes aduanales podrán constituir un máximo de cuatro sociedades para facilitar la prestación de sus servicios, y deberán:

I. Ser socios accionistas de las mismas;

II. Constituir la sociedad ante notario o corredor público, y

III. Presentar ante el SAT una copia certificada del acta constitutiva de la sociedad en términos del artículo 162, fracción XII de la Ley, sin perjuicio de acreditar su inscripción en los registros que deban realizar conforme a su naturaleza y en los términos de lo previsto por las disposiciones jurídicas aplicables.

\section{OTORGAMIENTO DE UNA PATENTE CORPORATIVA}

Consideramos que, dadas las circunstancias actuales bajo las cuales se desarrolla el comercio exterior, así como las actividades que desarrollan las agencias aduanales y los agentes aduanales, sí debería contemplarse la posibilidad en la Ley del otorgamiento de una patente corporativa.

En la práctica, esa patente podría representar un paso muy importante en la reconfiguración de los responsables del trámite del despacho aduanero, ya que ayudaría, entre otras cosas, a clasificar las responsabilidades de las personas que realmente reali- 
zan las diferentes tareas dentro del procedimiento del despacho aduanero.

Este capítulo es un ejemplo de que es viable y además necesario que se reforme la Ley para actualizarla a la realidad respecto a la figura del agente aduanal, prever la figura de la agencia aduanal y la posibilidad del otorgamiento de una patente corporativa.

\section{DenOMinación DE "AGENGia ADUANAL"}

La agencia aduanal es una empresa, una persona jurídica o moral que se puede constituir bajo la denominación de cualquier tipo de sociedad de las reconocidas en la legislación mercantil mexicana.

En Colombia, la normativa señala que "las personas jurídicas que pretendan ejercer el agenciamiento aduanero deberán incluir en su razón social o denominación la expresión «agencia de aduanas» seguida del nombre comercial, de la sigla correspondiente a la naturaleza mercantil de la sociedad y del nivel de agencia de aduanas". ${ }^{42}$

Por su parte, en Chile, la Ordenanza de Aduanas señala en el artículo 198:

La constitución de estas sociedades deberá sujetarse al cumplimiento de los siguientes requisitos:

a) La razón social principiará con la expresión "agencia de aduanas", seguida únicamente por el nombre del despachador o el de alguno de ellos y las expresiones legales que indiquen la naturaleza de la compañía...

En nuestro país, las agencias aduanales se constituyen con base en la legislación mercantil y no se exige que lleven en su denominación la expresión "agencia aduanal". Es decir, se trata de una empresa de naturaleza mercantil.

42 Parágrafo 1 del artículo 12 del Decreto 2883 de Colombia. 


\section{TIPOS DE AGENGIAS ADUANALES}

En otros países, como es el caso de Colombia, existen diferentes tipos de agencias aduanales. La propia normativa establece cómo se clasifican y los requisitos específicos para su constitución. Señala el artículo 12 del Decreto 2883 que las agencias de aduanas se clasifican en los siguientes niveles:

1. Agencias de aduanas nivel 1.

2. Agencias de aduanas nivel 2.

3. Agencias de aduanas nivel 3.

4. Agencias de aduanas nivel 4.

Asimismo, el artículo 14 del ordenamiento antes señalado establece como requisito:

4. Poseer y soportar contablemente el patrimonio líquido mínimo exigido para el respectivo nivel de agencia de aduanas, así:

a) Agencia de aduanas nivel 1: Tres mil quinientos millones de pesos $(\$ 3.500 .000 .000)$.

b) Agencia de aduanas nivel 2: Cuatrocientos treinta y ocho millones doscientos mil pesos (\$438.200.000).

c) Agencia de aduanas nivel 3: Ciento cuarenta y dos millones quinientos mil pesos (\$142.500.000).

d) Agencia de aduanas nivel 4: Cuarenta y cuatro millones de pesos $(\$ 44.000 .000)$.

Dicho patrimonio deberá mantenerse actualizado en la forma indicada en el artículo 18 del presente decreto.

La Ley Aduanera podría señalar, en el capítulo respectivo, una regulación similar, dependiendo del tipo o las características de la aduana que se pretenda constituir. Por ejemplo, podría tomar como base para la clasificación de las aduanas, si éstas son fronterizas, marítimas o interiores. 
Las fronterizas son las que se encuentran en los límites del país con los países colindantes; las marítimas se encuentran en puertos autorizados del territorio nacional, y las interiores se ubican al interior de la República mexicana. ${ }^{43}$

\section{REQUISITOS PARA LA CONSTITUGIÓN DE LA AGENGIA}

La Ley Aduanera, en nuestro país, únicamente señala los requisitos para el otorgamiento de la patente aduanal a una persona física, pero es omisa en señalar los requisitos para la constitución de la "agencia aduanal".

En Colombia, conforme a lo dispuesto en el artículo 14 del Decreto 2883,

Para ejercer la actividad de agenciamiento aduanero se deberá cumplir con los siguientes requisitos generales:

1. Estar debidamente constituida como sociedad de naturaleza mercantil o sucursal de sociedad extranjera domiciliada en el país;

2. Tener como objeto social exclusivo el agenciamiento aduanero, excepto en el caso de los almacenes generales de depósito;

3. Estar debidamente inscrita en el Registro Único Tributario, RUT;

4. Poseer y soportar contablemente el patrimonio líquido mínimo exigido para el respectivo nivel de agencia de aduanas...;

5. No tener deudas exigibles por concepto de impuestos, anticipos, retenciones, derechos de aduana, intereses, sanciones o cualquier otro concepto administrado por la Dirección de Impuestos y Aduanas Nacionales, salvo que exista acuerdo de pago vigente;

6. Contratar personas idóneas profesionalmente, con conocimientos específicos o experiencia relacionada con la actividad de comercio exterior;

43 Artículo 7o. del Reglamento Interior del Servicio de Administración Tributaria. 
7. No encontrarse incursa la sociedad, sus socios, accionistas, administradores, representantes legales o sus agentes de aduanas en las causales de inhabilidad o incompatibilidad previstas en el artículo 27-6 del presente decreto;

8. Contar con una infraestructura financiera, física, técnica, administrativa y, con el recurso humano que permita ejercer de manera adecuada la actividad de agenciamiento aduanero;

9. Aprobar las evaluaciones de conocimiento técnico que realice la Dirección de Impuestos y Aduanas Nacionales o un tercero autorizado por esta entidad;

10. Disponer y cumplir con el código de ética a que se refiere el artículo 26 del presente decreto;

11. Obtener la autorización como agencia de aduanas.

Por su parte, en Chile, el artículo 198 de la Ordenanza de Aduanas señala:

Con el objeto de explotar los servicios inherentes al despacho de mercancías, los agentes de aduana podrán asociarse con otros agentes de aduana o con personas naturales y formar con ellas únicamente sociedades colectivas y de responsabilidad limitada, pero sin que la compañía pueda actuar como agente ante la aduana.

La constitución de estas sociedades deberá sujetarse al cumplimiento de los siguientes requisitos:

a) La razón social principiará con la expresión "Agencia de Aduanas", seguida únicamente por el nombre del despachador o el de alguno de ellos y las expresiones legales que indiquen la naturaleza de la compañía;

b) El capital social no podrá ser inferior a 5.000 unidades de fomento;

c) El o los agentes de aduana no podrán ser excluidos de la administración de la sociedad ni del uso de la razón social;

d) En caso de que la sociedad esté compuesta por dos o más agentes de aduana, el aporte total de los agentes no podrá ser inferior al $51 \%$ y el aporte individual de cada uno no podrá ser inferior al 20\% del capital social y su participación en las utilidades y 
pérdidas de la compañía será, a lo menos, proporcional a su aporte. Asimismo, en este caso, cada socio no agente no podrá realizar un aporte ni tener una participación en las utilidades y pérdidas igual o superior al de cada uno de los agentes individualmente considerados.

Tratándose de sociedades en que participe sólo un agente de aduana, su aporte no podrá ser inferior al 51\% del capital social y su participación en las utilidades y pérdidas de la compañía será, a lo menos, proporcional a su aporte.

Esta regla podrá ser alterada estableciéndose un porcentaje menor de participación para el agente de aduana en las utilidades y en las pérdidas, cuando los demás socios hayan sido auxiliares del mismo durante un tiempo no inferior a cinco años. Con todo, siempre el agente de aduana tendrá una participación igual o superior a la de los demás socios individualmente considerados;

e) Los socios no agentes de aduana deberán aportar siempre trabajo personal;

f) El plazo de la sociedad no podrá exceder de cinco años, sin perjuicio de que el director nacional autorice cada vez la prórroga correspondiente, $\mathrm{y}$

g) El estatuto social deberá consignar que la sociedad será solidariamente responsable con el o los agentes de cualquiera obligación patrimonial de éstos ante la aduana.

Ninguna persona podrá ser socio en más de una compañía de esta clase y ningún agente de aduana podrá ejercer sus funciones independientemente de la que forme parte.

Las legislaciones mercantil y civil son las que señalan los requisitos para la constitución de una persona jurídica o moral bajo las denominaciones que establece la propia ley.

\section{AUTORIZACIÓN DE LA CONSTITUCIÓN DE LA AGENCIA ADUANAL}

En nuestro país, el Servicio de Administración Tributaria es el órgano competente para otorgar la patente aduanal, pero la agencia 
aduanal se constituye ante notario público conforme a las disposiciones de la legislación civil y mercantil.

Por el contrario, en Chile, el artículo 198 de la Ordenanza de Aduanas señala:

El director nacional de aduanas deberá verificar que en el proyecto de escritura social se dé cumplimiento a las exigencias establecidas en el inciso segundo de este artículo. Otorgada su conformidad y celebrado el contrato, deberá remitirse al director nacional de aduanas copia autorizada de la escritura pública de constitución para los efectos de su comprobación, comunicación y registro. Las prórrogas y las demás modificaciones del estatuto social deberán someterse a los mismos trámites señalados precedentemente.

Se señalan en el acta constitutiva algunas facultades específicas para la nueva empresa mercantil, que es la nueva agencia aduanal, mismas que tendrá que realizar el agente aduanal como titular de la patente aduanal.

\section{ORGANIZACIÓN DE LA AGENCIA ADUANAL}

\section{Agencia aduanal}

Las agencias aduanales, como empresas, están organizadas de diferente manera. Cada una cuenta con el número de personas acorde con el volumen de sus operaciones y con sus actividades.

La gran mayoría, además de ofrecer los servicios propios de la entrada y salida de las mercancías del territorio, ofrece servicios adicionales como asesoría o consultoría en materia de comercio exterior, entre muchos otros.

Los servicios que presta el agente aduanal a los importadores o exportadores, y a las demás personas, por conducto de la agen- 
cia, son pagados a esta última. Es decir, la agencia expide una factura, no el agente aduanal.

Las responsabilidades son del agente, actuando como agente, pero no de la agencia, a pesar de que esta última es la que expide la factura.

Incluso, en la Octava Época, el Tercer Tribunal Colegiado del Cuarto Circuito, en una tesis aislada, señaló esa situación al destacar que "el pedimento de importación tramitado por una agencia aduanal a nombre de la quejosa en su carácter de importadora... Lo cual demuestra esta situación, que los propios clientes no saben quién es el responsable, si la agencia que expide la factura o el agente que firma el pedimento".

\section{Agente aduanal}

Es la persona física autorizada por la Ley Aduanera para realizar muchas de las actividades señaladas en la legislación aduanera y fiscal. Las normativas tanto aduanera como fiscal establecen las obligaciones a cargo del agente aduanal, aunque en la práctica dichas actividades sean encomendadas a diferentes personas que trabajan en la agencia aduanal.

En particular, la Ley Aduanera, en su artículo 162, señala las obligaciones del agente aduanal, aunque en la práctica esas actividades las realizan otras personas que trabajan en la agencia. Sería prácticamente imposible que el agente aduanal llenara todos los pedimentos o realizara las actividades que señala la Ley sin la ayuda de otras personas. Pero la Ley así lo establece: el agente aduanal es el responsable de la patente aduanal y de las actividades que se realicen al amparo de dicha patente.

\section{Gerente o director general}

Todas las agencias aduanales cuentan con un gerente general o director general. 
4. Representante legal

Las agencias aduanales cuentan con un representante legal, que puede ser el mismo agente aduanal, uno de los socios y/o el mandatario.

\section{Mandatarios}

De acuerdo con los artículos 160, fracción VI, y 162, fracción XIII, de la Ley Aduanera, el agente aduanal puede acreditar ante cada aduana en la que ejerza la patente a, al menos, un mandatario autorizado por la autoridad aduanera.

Es decir, cuando el agente aduanal requiera ser auxiliado en los trámites del despacho, podrá designar al menos a un mandatario por cada aduana adicional a la de su adscripción.

En caso de no requerir el auxilio en los trámites para el despacho aduanero de las mercancías en las aduanas que tiene autorizadas o en su aduana de adscripción, no requerirá designar a un mandatario.

Aunque esta opción de acreditar mandatario es una facultad para el agente aduanal.

En ese sentido, "el agente aduanal será ilimitadamente responsable por los actos de sus empleados o dependientes autorizados y de sus mandatarios".

Asimismo,

Para ser mandatario aduanal autorizado de agente aduanal se requiere contar con poder notarial y demostrar experiencia aduanera mayor a tres años, aprobar el examen y cumplir los demás requisitos que determine el Servicio de Administración Tributaria mediante reglas. Cada mandatario aduanal promoverá solamente el despacho en representación de un agente aduanal y ante 
una sola aduana, salvo uno de los mandatarios, que podrá actuar indistintamente en cualquiera de las aduanas autorizadas.

\section{Otros dependientes}

Algunas empresas constituidas como agencias aduanales contemplan organigramas amplios, ya que cuentan con áreas encargadas de tramitar no sólo el despacho aduanal, sino que además realizan otras actividades relacionadas con el comercio exterior. Pero básicamente cuentan con áreas que toda empresa posee: contabilidad, jurídica, administración, auditoría, comercial, ventas, finanzas y recursos humanos.

\section{DisOLUCiÓN DE LA AGENGIA ADUANAL}

Como lo señalamos en el capítulo anterior, el artículo 165 de la Ley Aduanera señala las causas de cancelación de la patente aduanal, pero no de la disolución de la persona jurídica, esto es, de la agencia aduanal.

La agencia aduanal en México se puede disolver por diferentes causas señaladas en la legislación mercantil, civil o penal, pero no por una resolución administrativa que derive de una sanción de la autoridad administrativa al agente aduanal.

Por el contrario, en Chile,

El director nacional, por resolución fundada, podrá ordenar la disolución de alguna de estas sociedades, si motivos de conveniencia pública así lo aconsejaren. En particular será causal para ordenar la disolución de la sociedad el hecho de que las actividades que ejecuten los socios o sus vínculos jurídicos con personas naturales o jurídicas atenten en contra de la independencia del agente de aduana en el ejercicio de sus funciones. ${ }^{44}$

44 Artículo 198 de la Ordenanza de Aduanas. 


\section{SANCiOnes A LOS DEPENDIENTES \\ DE LA AGENCIA ADUANAL}

Los dependientes de la agencia aduanal sólo pueden ser sancionados, en su calidad de trabajadores, en términos de la legislación laboral, pero sus equivocaciones o errores en muchos casos repercutirán en el agente aduanal, ya que la Ley sólo se refiere al agente aduanal, pero nunca a sus dependientes, que son, en muchas ocasiones, los que desarrollan las actividades encomendadas por la Ley al agente aduanal. 


\section{RESPONSABILIDADES DE LOS AGENTES ADUANALES Y DE SUS DEPENDIENTES EN RELACIÓN CON EL PROCEDIMIENTO DE DESPACHO ADUANERO}

\section{INTRODUGGIÓN}

El agente aduanal es el responsable del uso de la patente aduanal, pero también de algunas de las actividades que realizan sus dependientes y sus mandatarios.

Tiene responsabilidades, asimismo, de carácter fiscal y aduanero.

Además, el agente aduanal y su agencia aduanal son responsables en dos vertientes: frente a sus clientes y frente a las autoridades fiscales y aduaneras.

Consideramos que algunas disposiciones de la Ley Aduanera y del Reglamento son contradictorias y que además causan inseguridad jurídica, ya que mientras el artículo 160, fracción V, de la Ley Aduanera señala las obligaciones del agente aduanal, entre las que se encuentra que el agente aduanal debe "ocuparse personal y habitualmente de las actividades propias de su función", el artículo 162, fracción XIII, lo obliga a "ocuparse, en su aduana de adscripción, por lo menos, del 15\% de las operaciones de importación y exportación con valor que no rebase al que, mediante reglas, determine el Servicio de Administración Tributaria”, y el artículo 163, fracción IV, le da derecho a "designar hasta cinco mandatarios". 
Además de lo anterior, el artículo 162, fracción XI, lo obliga a "acreditar, en su caso, ante cada aduana en la que ejerza la patente al menos a un mandatario autorizado por la autoridad aduanera". Y el artículo 235 del Reglamento dispone que "para efectos del artículo 195 de la Ley, se consideran actos realizados por el agente aduanal en el despacho aduanero de las mercancías, los derivados de la tramitación de pedimentos que firmen el propio agente aduanal o sus mandatarios acreditados legalmente para ello".

Situaciones que evidencian lo desproporcionado de las responsabilidades de las personas que llevan a cabo el despacho aduanero, ya que toda la responsabilidad es del agente aduanal.

Además de lo anterior, el artículo 162 y otras disposiciones de la Ley Aduanera establecen obligaciones para los agentes aduanales, que señalamos en cada etapa del procedimiento y que puede ser que el agente aduanal no realice personalmente. Son las siguientes:

I. En los trámites o gestiones aduanales, actuar siempre con su carácter de agente aduanal. ${ }^{45}$

III. Rendir el dictamen técnico cuando se lo solicite la autoridad competente.

45 En ese sentido, por ejemplo, el Primer Tribunal Colegiado en Materias Penal y Administrativa del Décimo Séptimo Circuito ha señalado que "si una vez iniciado el reconocimiento aduanero se suspende por causa de la autoridad, la cual se asienta en el acta y se comunica mediante oficio al administrador de la aduana, y el agente aduanal participa en dicha comunicación manifestando su consentimiento expreso, al firmarla de enterado y de conformidad, para continuar y concluir la revisión en fecha posterior, no se requiere renuncia expresa del importador o exportador al principio de inmediatez a que debe sujetarse dicha actuación, toda vez que en términos del artículo 41 de la Ley Aduanera, el agente aduanal es su representante durante el trámite del despacho aduanero de mercancías y, por tanto, actúa en su nombre”. Véase tesis aislada XVII.1 lo.P.A.43A, Primer Tribunal Colegiado en Materias Penal y Administrativa del Décimo Séptimo Circuito, Semanario fudicial de la Federación y su Gaceta, Novena Época, t. XXXII, octubre de 2010, p. 3167. 
IV. Cumplir el encargo que se le hubiera conferido, por lo que no podrá transferirlo ni endosar documentos que estén a su favor o a su nombre, sin la autorización expresa y por escrito de quien lo otorgó.

VIII. Solicitar la autorización de las autoridades aduaneras para poder suspender sus actividades, en los casos previstos en esta Ley.

XII. Someterse a los exámenes a los que podrá convocar anualmente de manera general el Servicio de Administración Tributaria. Éste deberá publicar las reglas de carácter general en las que se establecerán los lineamientos para la aplicación de los exámenes que realizarán instituciones académicas o especializadas en evaluación y que estén debida y previamente acreditadas ante el Servicio de Administración Tributaria. Todos los costos que se generen con motivo de la aplicación de los exámenes correrán a cargo de los agentes aduanales.

Asimismo, deberá usar el gafete de identificación personal en los recintos fiscales en que actúe; obligación que también deben cumplir sus empleados o dependientes autorizados y sus mandatarios. ${ }^{46}$

Precisamente en este capítulo, además de describir el procedimiento de despacho aduanero en términos generales, destacamos las responsabilidades de quienes lo realizan y señalamos las personas encargadas de esos trámites.

\section{FORMACIÓN DEL EXPEDIENTE DEL IMPORTADOR O EXPORTADOR Y DETERMINAGIÓN DEL RÉGIMEN ADUANERO}

El importador, para que pueda realizar cualquiera de las actividades a las que quiera destinar sus productos, debe señalarle a la

46 Artículos 160, fracción VI, y 17 de la Ley Aduanera. 
agencia aduanal dicha situación para que determine el régimen aduanero correspondiente, que puede ser: importación definitiva, importación temporal, depósito fiscal, tránsito de mercancías nacional o internacional, elaboración, transformación o reparación en recinto fiscalizado o el régimen de recinto fiscalizado estratégico.

En este primer momento se realiza la conformación de un expediente con la documentación que corresponde al régimen aplicable de importación, de conformidad con el artículo 36 de la Ley Aduanera.

$\mathrm{Al}$ respecto, el artículo 162 de la Ley Aduanera señala que es obligación del agente aduanal:

V. Declarar, bajo protesta de decir verdad, el nombre y domicilio fiscal del destinatario o del remitente de las mercancías, la clave del Registro Federal de Contribuyentes de aquéllos y el propio, la naturaleza y características de las mercancías y los demás datos relativos a la operación de comercio exterior en que intervenga, en las formas oficiales y documentos en que se requieran o, en su caso, en el sistema mecanizado.

VI. Formar un archivo electrónico de cada uno de los pedimentos con la información transmitida y presentada en mensaje o documento electrónico o digital como parte de sus anexos conforme a los artículos 6o., 36 y 36-A de la presente Ley y demás disposiciones aplicables.

Adicionalmente, deberá conservar el original de la manifestación de valor a que se refiere el artículo 59, fracción III, de esta Ley, así como copia del documento presentado por el importador a la Administración General de Aduanas que compruebe el encargo que se le hubiere conferido para realizar el despacho aduanero de las mercancías, y si éste fue otorgado de forma electrónica deberá conservar el acuse correspondiente.

Con independencia de las demás obligaciones fiscales, el archivo electrónico deberá conservarse por los plazos establecidos en el Código Fiscal de la Federación.

Los archivos electrónicos que se generen en términos de esta fracción, deberán ser proporcionados a los clientes que les co- 
rrespondan, sin cargo adicional, quienes tendrán la obligación de conservarlos en términos de lo establecido por el tercer párrafo del artículo 6o. de esta Ley.

Al respecto, el Poder Judicial de la Federación ha destacado que:

De los artículos 35, 53, fracción II, y 54, fracción I, de la Ley Aduanera se advierte que el agente aduanal tiene responsabilidad solidaria en el pago de impuestos al comercio exterior y demás contribuciones que se causen con motivo de las importaciones o exportaciones en cuyo despacho aduanero intervenga personalmente o por conducto de sus empleados, en alguno de los supuestos siguientes: a) cuando carecen de veracidad o exactitud los datos proporcionados; b) en caso de que no sea correcta la determinación del régimen aduanero o la clasificación arancelaria; y, c) cuando se incumplen las demás obligaciones en materia de regulaciones y restricciones, siempre que le sean imputables. Ahora bien, dicha responsabilidad no se limita a la conclusión del despacho aduanero, sino que está sujeta al alcance de la actuación del agente aduanal, la que puede tener efectos o repercusiones aun después de concluido aquél, por estar vinculada con las obligaciones que le corresponden con motivo del trámite aduanero, como en el caso en que, mediante el ejercicio de las facultades de comprobación en términos del artículo 43 de la citada ley, se determine alguna omisión, inexactitud o falsedad en los datos proporcionados. ${ }^{47}$

\section{RECONOCIMIENTO PREVIO}

El artículo 42 de la Ley Aduanera dispone que "si quien debe formular el pedimento ignora las características de las mercancías en depósito ante la aduana, podrá examinarlas para ese efecto”. Esto

47 Tesis aislada XIX.1o.A.C.35 A, Semanario Fudicial de la Federación y su Gaceta, Novena Época, t. XXVII, abril de 2008, p. 2287. 
con la finalidad de que las personas que trabajan en la agencia aduanal, que son especialistas en la materia, puedan revisar las mercancías para clasificarlas, revisar si están completas, etcétera, y llenar adecuadamente el pedimento.

Relacionado con esta actividad está lo dispuesto en la fracción XIV del artículo 1o. de la Ley Aduanera, que dispone que se entiende por

Reconocimiento aduanero, el examen de las mercancías, así como de sus muestras que lleven a cabo las autoridades para allegarse de elementos que ayuden a cerciorarse de la veracidad de lo declarado ante la autoridad aduanera, así como del cumplimiento de las disposiciones que gravan y regulan la entrada o salida de mercancías del territorio nacional.

Esta actividad de reconocimiento previo que realizan muchas agencias aduanales es muy importante, en virtud de que el artículo 54 de la Ley Aduanera dispone que

El agente aduanal será responsable de la veracidad y exactitud de los datos e información suministrados, de la determinación del régimen aduanero de las mercancías y de su correcta clasificación arancelaria, así como de asegurarse que el importador o exportador cuenta con los documentos que acrediten el cumplimiento de las demás obligaciones que en materia de regulaciones y restricciones no arancelarias rijan para dichas mercancías, de conformidad con lo previsto por esta Ley y por las demás leyes y disposiciones aplicables.

La Ley señala, de acuerdo con lo anterior, que es responsabilidad del agente aduanal; sin embargo, en la práctica, dicha actividad no la realiza el agente aduanal, pues resulta imposible que una sola persona realice dichas actividades por el volumen de las mercancías que entran a nuestro territorio nacional.

Por ello, consideramos que sería importante la creación de la patente corporativa y señalar en la Ley las responsabilidades 
de cada persona que trabaja en la agencia aduanal, acorde a sus específicas actividades dentro del procedimiento respectivo, y no dejar toda la responsabilidad en la persona del agente aduanal como lo dispone actualmente la Ley Aduanera.

Guando en el reconocimiento aduanero se requiera efectuar la toma de muestras de mercancías estériles, radiactivas, peligrosas o cuando sean necesarias instalaciones o equipos especiales para la toma de las mismas, los importadores, exportadores o los agentes aduanales, cuando actúen por cuenta de aquéllos, las deberán tomar previamente a efecto de que sean presentadas al momento del reconocimiento aduanero. En todo caso, se podrán tomar las muestras al momento del reconocimiento aduanero, en los términos que establezca el Reglamento. ${ }^{48}$

\section{CLASIFICACiÓN ARANCELARIA}

La clasificación arancelaria es una actividad que realiza el agente aduanal para llevar a cabo el despacho aduanero, de la cual el agente es el responsable.

La Ley Aduanera, en su artículo 54, como lo señalamos antes, dispone que el responsable es el agente aduanal, pero en la práctica esta actividad la realiza el agente aduanal con el apoyo de especialistas en la materia.

Al respecto, el artículo 81 de la Ley Aduanera señala que:

Los importadores y exportadores o los agentes aduanales, cuando actúen por cuenta de aquéllos, determinarán las contribuciones y, en su caso, las cuotas compensatorias, para lo cual manifestarán en el pedimento o documento aduanero de que se trate, bajo protesta de decir verdad respecto de las mercancías:

I. Su descripción, estado y origen.

II. Su valor en aduana, así como el método de valoración utilizado y, en su caso, la existencia de vinculaciones a que se refiere

48 Artículo 45 de la Ley Aduanera vigente. 
el artículo 68 de esta Ley en el caso de importación, o el valor comercial tratándose de exportación.

III. Su clasificación arancelaria.

IV. El monto de las contribuciones causadas con motivo de su importación o exportación y, en su caso, las cuotas compensatorias. $^{49}$

La Segunda Sala de la Suprema Corte de Justicia de la Nación ha señalado que:

Este numeral dispone que el agente aduanal no será responsable solidario por el pago de las diferencias de contribuciones, cuotas compensatorias, multas y recargos que se determinen, así como por el incumplimiento de regulaciones y restricciones no arancelarias, si éstos provienen de la inexactitud o falsedad de los datos y documentos que el contribuyente le hubiera proporcionado, siempre que dicho agente no hubiera podido conocer las mencionadas irregularidades "por no ser apreciable a la vista y por requerir para su identificación de análisis químico, o de análisis de laboratorio tratándose de las mercancías que mediante reglas establezca la Secretaría”. De su interpretación literal se obtiene que la práctica de los referidos análisis, para que al agente aduanal no le resulte responsabilidad solidaria, sólo es necesaria cuando se trate de las mercancías especificadas mediante reglas por la Secretaría de Hacienda y Crédito Público, mientras que tratándose de cualesquiera otras mercancías, bastará que se demuestre que la inexactitud o falsedad no sea apreciable a la vista. Cabe precisar que si bien la conjunción copulativa "y" denota que los requisitos en comento se encuentran vinculados, ello no implica que indefectiblemente deban satisfacerse ambos, ya que la exigencia de que se realicen los mencionados análisis se encuentra limitada a las mercancías incluidas en las reglas referidas. ${ }^{50}$

49 Artículo 81 de la Ley Aduanera vigente.

50 Tesis de jurisprudencia 2a./J.27/2005, Segunda Sala, Semanario fudicial de la Federación, Novena Época, t. XXI, marzo de 2005, p. 227. 


\section{PeDimento}

El pedimento, de acuerdo con lo señalado en el artículo 2o., fracción XIV, de la Ley Aduanera, es

...la declaración en documento electrónico, generada y transmitida respecto del cumplimiento de los ordenamientos que gravan y regulan la entrada o salida de mercancías del territorio nacional, en la que se contiene la información relativa a las mercancías, el tráfico y régimen aduanero al que se destinan, y los demás datos exigidos para cumplir con las formalidades de su entrada o salida del territorio nacional, así como la exigida conforme a las disposiciones aplicables.

Para los efectos del artículo 36, en relación con el artículo 60. de la Ley Aduanera, los agentes aduanales y quienes introduzcan o extraigan mercancías del territorio nacional para destinarlas a un régimen aduanero, están obligados a transmitir en documento electrónico o digital como anexos al pedimento, excepto lo previsto en las disposiciones aplicables, la información que se señala en el artículo 36-A de la Ley Aduanera, la cual deberá contener el acuse generado por el sistema electrónico aduanero, conforme al cual se tendrá por transmitida y presentada. ${ }^{51}$

Además de lo anterior, para efectos de los artículos 35, 36, 36-A, 37 y 37-A de la Ley Aduanera, en la introducción y extracción de mercancías por tráfico terrestre, los importadores y exportadores, sus representantes legales o los agentes aduanales deberán declarar en el pedimento o aviso consolidado los datos relativos al número económico de la caja o contenedor, el tipo de contenedor y vehículo de autotransporte, así como pagar el pedimento con por lo menos una hora de anticipación al ingreso o salida del territorio nacional de las mercancías. ${ }^{52}$

51 Artículo 36-A de la Ley Aduanera vigente.

52 Artículo 34 del Reglamento de la Ley Aduanera. 
$\mathrm{Al}$ respecto, el artículo 162 de la Ley Aduanera señala que es obligación del agente aduanal:

II. En los casos de las mercancías sujetas a regulaciones y restricciones no arancelarias cuyo cumplimiento se realice mediante documento electrónico o digital, anotar en el pedimento el acuse correspondiente.

IX. Manifestar en el pedimento o en el aviso consolidado, el número de candado oficial utilizado en los vehículos o medios de transporte que contengan las mercancías cuyo despacho promuevan.

\section{PRESENTAGión DE MERGANGías A DESPACHO}

Después de que se pagan las contribuciones, el agente aduanal presenta la mercancía, con la documentación correspondiente, en el mecanismo de selección automatizado, el cual puede determinar si se practica o no el reconocimiento aduanero.

En caso de desaduanamiento libre, o una vez concluido el reconocimiento aduanero, se permitirá la salida de las mercancías. 


\section{LA VIGILANGIA DE LOS AGENTES ADUANALES}

\section{EL PRINGIPIO DE LA DIVISIÓN DE PODERES}

La división de poderes es un principio mediante el cual se busca dividir el ejercicio del poder entre diversos órganos o entes que constitucionalmente se encuentran a un mismo nivel, con el fin de lograr los contrapesos necesarios que permitan un equilibrio de fuerzas y un control recíproco. En nuestro régimen constitucional el poder se divide, para su ejercicio, en tres funciones: la legislativa, la ejecutiva o administrativa y la judicial. ${ }^{53}$

Sin embargo, señala Miguel Carbonell, "en la actualidad se entiende que dentro de un Estado pueden haber funciones distintas a las anteriores o tareas que deban ser llevadas a cabo por órganos diferentes a los tradicionales"; 54 son los llamados órganos constitucionales autónomos.

\section{LA DIVISIÓN DE FUNGIONES Y LAS FUNGIONES EMERGENTES}

El principio de la división de poderes, pilar de nuestro sistema jurídico, también es interpretado en la actualidad como una división de funciones.

53 Tesis aislada 2a. CXXVIII/2001, Semanario Fudicial de la Federación y su Gaceta, México, Novena Época, Segunda Sala, t. XIV, agosto de 2001, p. 227.

54 Carbonell, Miguel, "Los órganos constitucionales autónomos en la Constitución mexicana", en López Olvera, Miguel Alejandro y Vocos Conesa, Juan Martín (coords.), Perspectivas del derecho público en el umbral del siglo XXI, Buenos Aires, Fundación de Derecho Administrativo, 2003, p. 121. 
Hablamos de función pública, señala Jorge Fernández Ruiz, para referirnos a la actividad esencial y mínima del Estado contemporáneo, fundada en la idea de soberanía, que conlleva el ejercicio de potestad, de imperio, de autoridad - de donde su indelegabilidad -, cuya realización atiende al interés público, entre las que destacan la función legislativa, la función jurisdiccional y la función administrativa. ${ }^{55}$

Con el transcurrir del tiempo, al lado de las funciones tradicionales que desempeña el Estado (legislativa, ejecutiva y judicial) han surgido otras que, en algunos casos, como lo señalamos antes, son ejercidas por órganos que no pertenecen a los depositarios tradicionales del poder público. A estas nuevas funciones se les denomina por parte de la doctrina "emergentes". Una de estas funciones es la de verificación o de inspección. Se trata de una función administrativa que queda atribuida a los órganos del Poder Ejecutivo, tanto federal como estatales y municipales.

Se les denomina funciones a estas actividades que realiza el Estado porque este último tiene el monopolio para realizarlas. Las funciones de control, de verificación o de inspección, entre otras, no podrían ser realizadas por un particular, pues ello traería consecuencias muy graves para las personas.

\section{LA FUNCIÓN DE VIGILANCIA}

\section{El poder de policía}

El concepto "poder de policía" se refiere a la facultad del Estado de "vigilar que los particulares cumplan con lo dispuesto por las normas de orden público (sentido lato)". ${ }^{56}$

55 Fernández Ruiz, Jorge, "Los organismos públicos constitucionalmente autónomos", en Olivos Campos, José René, La administración del Estado contemporáneo, México, Porrúa, 2009, p. 88.

56 Pleno, Semanario fudicial de la Federación, Séptima Época, t. 163-168, pri- 
Es el "conjunto de facultades que tienen las autoridades administrativas para vigilar la conducta de los particulares... y cerciorarse de que se ajusta a las normas de orden público aplicables, previniendo así la alteración de dicho orden". ${ }^{57}$

\section{La vigilancia del cumplimiento de las normas}

La doctrina y la jurisprudencia, en su mayor parte, emplean indistintamente los términos inspección, verificación y supervisión, para referirse a la facultad de vigilar el cumplimiento de las normas dictadas por una autoridad competente.

Juan Francisco Pérez Gálvez señala que los términos inspección y supervisión se distinguen por sus prefijos: in -en el caso de inspección - y super - en el caso de supervisión -; aquí estriba la principal diferencia de significados de los dos términos, en su prefijo.

Según lo que venimos diciendo, inspección equivaldría a "mirar dentro", "mirar en el interior". Supone, pues, una mirada profunda y penetrante capaz de ahondar en la realidad y ejercer presión sobre ella hasta obligarla a manifestarse; mientras que supervisión valdría tanto como "mirar sobre", "mirar desde arriba": es decir, pone de relieve la noción de actividad sobre; en resumen, mirada distante y panorámica, bien por la separación jerárquica que pueda mediar entre el que supervisa y lo supervisado, o porque la actuación supervisora no requiera de más proximidad. Implica, por tanto, el ejercicio de la autoridad de una manera muy concreta y determinada. La perspectiva de la mirada cercana en un caso, distanciada en otro, diferencia, en última instancia, general, lejana y la inspección como una acción más particularizada y concreta aunque de la misma naturaleza...

mera parte, p. 115. Véase, también, Vargas Morgado, Jorge, La policía. Condición jurídica, México, Novum, 2011, p. 7.

57 Pleno, Semanario fudicial de la Federación, Séptima Época, t. 163-168, primera parte, p. 115. 
Es decir, frente a otras formas más sutiles e indirectas de intervención, la de la inspección consiste en ver dejándose ver, y la supervisión en un actuar sin ser vistos. Es evidente que de ningún modo, como han creído algunos autores, puede pensarse que, etimológicamente, los términos inspección y supervisión tengan sentido antagónico, sino, más bien al contrario, confluyentes y complementarios..$^{58}$

Según el Diccionario de la Lengua Española, supervisar significa "ejercer la inspección superior en trabajos realizados por otros".

Se habla de función, facultad, potestad o simple actividad de inspección — señala José Bermejo Vera - para identificar un modo de actuar de todas las administraciones públicas, caracterizado, básicamente, por la imposición - generalmente forzosa - de supervisiones o controles sobre cómo se desarrollan ciertas actividades, qué contenido tienen los documentos, cómo se encuentran determinadas instalaciones, equipamientos u objetos, cómo están los productos, incluso en qué condiciones desempeñan su tarea algunas personas. ${ }^{59}$

En ese sentido, la Primera Sala de la Suprema Corte de Justicia de la Nación ha señalado que "el servicio que desempeñan los agentes aduanales, al ser una actividad privada de interés público, debe sujetarse a una estricta reglamentación y vigilancia estatal". ${ }^{60}$

58 Pérez Gálvez, Juan Francisco, Las agencias estatales para la mejora de los servicios públicos, Granada, Comares, 2007, p. 253.

59 Bermejo Vera, José, "Los principios ordenadores de la facultad de inspección de las administraciones públicas", en Hernández Mendible, Víctor (coord.), Derecho administrativo iberoamericano. 100 autores en homenaje al postgrado en derecho administrativo de la Universidad Católica Andrés Bello, Caracas, Ediciones Paredes, 2007 , p. 553.

60 Tesis aislada 1a. II/2007, Segunda Sala, "AgENTES ADUANALES. Los ARTículos 164, FRACCIÓN IV y 165, FRACCIÓN III, DE LA LEY ADUANERA, AL PREVER CAUSAS DE SUSPENSIÓN EN SUS FUNCIONES, ASÍ COMO DE CANCELACIÓN DE LA PATENTE RESPEGTIVA, NO TRANSGREDEN EL ARTÍCULO 25 


\section{La vigilancia del cumplimiento de las normas en materia aduanera}

La autoridades aduaneras son aquellas que en el ámbito de sus atribuciones, de acuerdo con la Constitución y la leyes federales, son competentes para ejercer las facultades de vigilancia y supervisión de los actores que intervienen en la actividad de comercio exterior que la Ley Aduanera establece; ${ }^{61}$ es decir, que de acuerdo con sus facultades pueden exigir y verificar el cumplimiento de la actividad de importación y exportación de mercancías, los impuestos y aranceles respectivos y, en general, hacer cumplir las normas aduaneras.

El artículo 3o. de la Ley Aduanera establece que "las funciones relativas a la entrada de mercancías al territorio nacional o a la salida del mismo son facultades exclusivas de las autoridades aduaneras".

Asimismo, la fracción II del artículo 2o. de la Ley Aduanera dispone que son autoridades aduaneras las que de acuerdo con el Reglamento Interior de la Secretaría de Hacienda y Crédito Público, y las demás disposiciones aplicables, tienen competencia para ejercer las facultades que la Ley Aduanera establece.

De lo anterior se puede deducir que la vigilancia de los actos, así como de los sujetos que intervienen en la materia aduanera, incluyendo a los agentes aduanales, le corresponde a la administración pública federal, en el ámbito de sus distintas competencias y delegaciones, que por ley o decreto involucran al presidente de la República, como responsable del Poder Ejecutivo Federal, o bien a diversas autoridades administrativas dependientes de la Secretaría de Hacienda y Crédito Público o del Servicio de Administración Tributaria, que por ley tiene diversas facultades y atribuciones en materia aduanal, y en las que se destaca en el presente trabajo la de verificación de los agentes aduanales.

DE LA Constitución FEDERAL (LEGISLACión VIGENTE En 2002)", Semanario Judicial de la Federación y su Gaceta, Novena Época, t. XXV, enero de 2007, p. 472.

61 Artículo 3o. de la Ley Aduanera. 


\section{LAS NORMAS JURÍDICAS}

\section{Su obligatoriedad}

Desde los más remotos orígenes del hombre fue necesario que éste se agrupara para poder enfrentar los problemas y conflictos que en la vida se presentaran.

Así, las personas han vivido desde su existencia en grupos sociales, llámense clan, familia, tribu, etcétera, pero siempre han tenido la necesidad de que su conducta sea guiada por reglas que las mismas personas imponen a través de los diferentes órganos competentes.

Este conjunto de reglas que norman la conducta de las personas en una sociedad recibe el nombre de "normas"; es decir, en toda sociedad organizada existe una serie de comportamientos o de conductas que se consideran necesarios para la convivencia y la consecución del fin de la misma; desde el momento en que estas conductas adquieren el carácter de obligatorias y su cumplimiento o incumplimiento comporta unas determinadas consecuencias, se puede hablar de normas jurídicas.

En ese sentido, la propia Ley Aduanera, en su artículo 1o., párrafo 2, establece que:

Están obligados al cumplimiento de las citadas disposiciones quienes introducen mercancías al territorio nacional o las extraen del mismo, ya sean sus propietarios, poseedores, destinatarios, remitentes, apoderados, agentes aduanales o cualesquiera personas que tengan intervención en la introducción, extracción, custodia, almacenaje, manejo y tenencia de las mercancías o en los hechos o actos mencionados en el párrafo anterior.

Como se puede apreciar, la norma jurídica se presenta entonces como una prescripción de una conducta o de un comportamiento obligatorio con carácter imperativo, de tal manera que 
su incumplimiento acarrea una consecuencia jurídica negativa, que es la sanción.

2. Facultad para expedir normas en materia aduanera por parte del Congreso de la Unión

En el ámbito de la materia aduanera, las disposiciones que la regulan derivan directamente de la Constitución Política de los Estados Unidos Mexicanos, y se reglamentan en otros ordenamientos legales de carácter federal, que han sido expedidos por el Congreso de la Unión, como la Ley Orgánica de la Administración Pública Federal, la Ley Aduanera, el Código Fiscal de la Federación, la Ley del Servicio de Administración Tributaria, entre otros.

\section{Competencia materialmente legislativa del presidente de la República}

La función legislativa puede ejercerse tanto formal como materialmente, de ahí que - como lo señalamos líneas adelante- el presidente de la República puede expedir reglamentos, como por ejemplo el Reglamento Interior de la Secretaría de Hacienda y Crédito Público, el Reglamento Interior del Servicio de Administración Tributaria, el Reglamento de la Ley Aduanera, por citar algunos en esta materia.

La Constitución Política de los Estados Unidos Mexicanos es la cúspide del orden normativo mexicano, en ella se estructura la organización de los poderes que rigen, entre los que destaca para esta investigación la del Poder Ejecutivo. Así, el artículo 80 establece: "Se deposita el ejercicio del Supremo Poder Ejecutivo de la Unión en un solo individuo, que se denominará «presidente de los Estados Unidos Mexicanos»".

Asimismo, el artículo 90 de la propia Constitución establece que: 
La administración pública será centralizada y paraestatal conforme a la Ley Orgánica que expida el Congreso, que distribuirá los negocios del orden administrativo de la Federación que estarán a cargo de las secretarías de Estado y definirá las bases generales de creación de las entidades paraestatales y la intervención del Ejecutivo Federal en su operación.

La propia Constitución Política de los Estados Unidos Mexicanos establece atribuciones conferidas al Poder Ejecutivo Federal materialmente legislativas, como la fracción I del artículo 89, que contiene la facultad reglamentaria que en materia aduanera da fundamento al Reglamento de la Ley Aduanera.

Artículo 89. Las facultades y obligaciones del presidente, son las siguientes:

I. Promulgar y ejecutar las leyes que expida el Congreso de la Unión, proveyendo en la esfera administrativa a su exacta observancia.

Otra facultad del Poder Ejecutivo Federal que se señala en la fracción X del propio artículo 89 de la Constitución es:

X. Dirigir la política exterior y celebrar tratados internacionales, así como terminar, denunciar, suspender, modificar, enmendar, retirar reservas y formular declaraciones interpretativas sobre los mismos, sometiéndolos a la aprobación del Senado. En la conducción de tal política, el titular del Poder Ejecutivo observará los siguientes principios normativos: la autodeterminación de los pueblos; la no intervención; la solución pacífica de controversias; la proscripción de la amenaza o el uso de la fuerza en las relaciones internacionales; la igualdad jurídica de los Estados; la cooperación internacional para el desarrollo; el respeto, la protección y promoción de los derechos humanos y la lucha por la paz y la seguridad internacionales.

Es importante señalar que de acuerdo con esta facultad, y en relación con el comercio exterior, la actividad comercial entre 
las diferentes naciones se lleva a cabo a través de tratados internacionales, con lo cual se pueden simplificar los mecanismos de importación y exportación de mercancías, además de respetar los convenios multilaterales como los de la Organización Mundial del Comercio, sus directivas y resoluciones.

Finalmente, en cuanto régimen constitucional, en el artículo 131 se establece una facultad extraordinaria por medio de la cual:

Es facultad privativa de la Federación gravar las mercancías que se importen o exporten, o que pasen de tránsito por el territorio nacional, así como reglamentar en todo tiempo y aún prohibir, por motivos de seguridad o de policía, la circulación en el interior de la República de toda clase de efectos, cualquiera que sea su procedencia; pero sin que la misma Federación pueda establecer, ni dictar, en el Distrito Federal, los impuestos y leyes que expresan las fracciones VI y VII del artículo 117.

El Ejecutivo podrá ser facultado por el Congreso de la Unión para aumentar, disminuir o suprimir las cuotas de las tarifas de exportación e importación, expedidas por el propio Congreso, y para crear otras; así como para restringir y para prohibir las importaciones, las exportaciones y el tránsito de productos, artículos y efectos, cuando lo estime urgente, a fin de regular el comercio exterior, la economía del país, la estabilidad de la producción nacional, o de realizar cualquiera otro propósito, en beneficio del país.

Resulta de suma importancia observar los criterios que la Suprema Corte de Justicia de la Nación ha emitido para interpretar esta facultad extraordinaria conferida al Ejecutivo Federal por el Congreso, en la tesis aislada 2a. CXXXVI/2009, que señala:

COMERGio EXTERIOR. FinALIDAD DE LAS FACUlTADES EXTRAORDINARIAS PARA LEGISLAR A GARGO DEL EJEGUTIVO FEDERAL DERIVADAS DEL PÁRRAFO SEGUNDO DEL ARTÍCULO 131 GOnstituaional. Conforme a los artículos 49, párrafo segundo, 
y 131, párrafo segundo, de la Constitución Política de los Estados Unidos Mexicanos, el presidente de la República, en uso de las facultades legislativas en materia de comercio exterior, puede: 1) Aumentar, disminuir o suprimir las cuotas de las tarifas de exportación e importación, expedidas por el Congreso de la Unión; 2) Crear otras cuotas o tarifas de exportación o importación; y, 3) Restringir y prohibir las importaciones, exportaciones y el tránsito de productos, artículos y efectos, cuando lo estime urgente, de donde se sigue que toda esa serie de facultades constitucionales constituye una especie del llamado derecho de emergencia, que tiende, en este caso, a posibilitar al Ejecutivo Federal a establecer de manera expedita, con rango de ley, cargas patrimoniales, prohibiciones y restricciones a la actividad de los particulares, a fin de regular de manera eficiente y ágil el comercio exterior, la economía del país, la estabilidad de la producción nacional u otro propósito similar, lo que permite responder a las fluctuaciones del intercambio de bienes con otros países, de ahí que las facultades extraordinarias para legislar a cargo del presidente de la República tienen como finalidad regular el comercio exterior (en lo particular) y la economía del país (en lo general).

Otro ordenamiento de carácter federal que confiere facultades al Ejecutivo Federal es el Código Fiscal de la Federación, que en su artículo 39 dispone que:

El Ejecutivo Federal mediante resoluciones de carácter general podrá:

I. Condonar o eximir, total o parcialmente, el pago de contribuciones y sus accesorios, autorizar su pago a plazo, diferido o en parcialidades, cuando se haya afectado o trate de impedir que se afecte la situación de algún lugar o región del país, una rama de actividad, la producción o venta de productos, o la realización de una actividad, así como en casos de catástrofes sufridas por fenómenos meteorológicos, plagas o epidemias. Sin que las facultades otorgadas en esta fracción puedan entenderse referidas a los casos en que la afectación o posible afectación a una determinada rama de la industria obedezca a lo dispuesto en una ley tributaria federal o tratado internacional. 
II. Dictar las medidas relacionadas con la administración, control, forma de pago y procedimientos señalados en las leyes fiscales, sin variar las disposiciones relacionadas con el sujeto, el objeto, la base, la cuota, la tasa o la tarifa de los gravámenes, las infracciones o las sanciones de las mismas, a fin de facilitar el cumplimiento de las obligaciones de los contribuyentes.

III. Conceder subsidios o estímulos fiscales.

Las resoluciones que conforme a este artículo dicte el Ejecutivo Federal, deberán señalar las contribuciones a que se refieren, salvo que se trate de estímulos fiscales, así como el monto o proporción de los beneficios, plazos que se concedan y los requisitos que deban cumplirse por los beneficiados.

En general, en este artículo se faculta al Ejecutivo Federal para que mediante resoluciones de carácter general, incluyendo la materia aduanera: condone o exima, total o parcialmente, el pago de contribuciones y sus accesorios, así como autorizar el pago de dichas contribuciones a plazo o parcialidades; dictar las medidas relacionadas con la administración, control, forma de pago y procedimientos señalados en las leyes fiscales, y conceder subsidios o estímulos fiscales.

No obstante lo anterior, respecto a la vigilancia, es la fracción II la que faculta al Ejecutivo Federal para dictar medidas relacionadas con el control, entendiendo la vigilancia como una forma de control, en el caso particular de los procedimientos aduaneros en los que finalmente se generan contribuciones y obligaciones fiscales que repercuten directamente en los procedimientos aduaneros, aunque podemos señalar que en este caso se refiere a la materia eminentemente fiscal.

\section{Competencia materialmente legislativa de la Secretaría de Hacienda y Crédito Público}

La Ley Orgánica de la Administración Pública Federal establece las bases de organización de la administración pública fe- 
deral centralizada y paraestatal. En este orden de ideas, el Ejecutivo Federal, para el ejercicio de sus atribuciones y el despacho de los negocios administrativos encomendados al Poder Ejecutivo de la Unión, se auxiliará de diversas dependencias centralizadas o paraestatales.

La Secretaría de Hacienda y Crédito Público, que es una de ellas, tiene entre sus facultades materialmente legislativas la señalada en la fracción XXXIV del artículo 6o. de su Reglamento Interior: "Artículo 6o. El secretario tendrá las siguientes facultades no delegables: ...XXXIV. Dictar las reglas de carácter general en las materias competencia de la Secretaría".

Esta disposición se refiere a las reglas en materia de comercio exterior, es decir, la Resolución Miscelánea de Comercio Exterior, que son reglas generales para la aplicación de tratados internacionales en materia de comercio exterior. Dichas reglas deben incluir métodos de verificación y sanción para que se cumpla con el espíritu de la ley.

También encontramos en el artículo 144 de la Ley Aduanera las siguientes facultades materialmente legislativas que revisten una gran importancia, que son:

Artículo 144. La Secretaría tendrá, además de las conferidas por el Código Fiscal de la Federación y por otras leyes, las siguientes facultades:

VIII. Fijar los lineamientos para las operaciones de carga, descarga, manejo de mercancías de comercio exterior y para la circulación de vehículos dentro de los recintos fiscales y fiscalizados y señalar dentro de dichos recintos las áreas restringidas para el uso de aparatos de telefonía celular, o cualquier otro medio de comunicación; así como ejercer en forma exclusiva el control y vigilancia sobre la entrada y salida de mercancías y personas en dichos lugares, en los aeropuertos y puertos marítimos autorizados para el tráfico internacional y en las aduanas fronterizas. 
XXIII. Expedir, previa opinión de la Secretaría de Economía, reglas para la aplicación de las disposiciones en materia aduanera de los tratados o acuerdos internacionales de los que México sea parte.

Respecto a la Unidad de Inteligencia Financiera, en la fracción XXIII del artículo 15 del Reglamento Interior de la Secretaría de Hacienda y Crédito Público se establece:

Artículo 15. Compete a la Unidad de Inteligencia Financiera:

XXIII. Establecer los lineamientos y programas en materia de recepción y análisis de la información, documentación, datos e imágenes que obtenga, de conformidad con las disposiciones de carácter general a que se refiere la fracción I de este artículo, la Ley Federal para la Prevención e Identificación de Operaciones con Recursos de Procedencia Ilícita, su Reglamento y demás disposiciones que de éstos emanen, y en las declaraciones a que se refiere el artículo 9o. de la Ley Aduanera.

Además, otros órganos que realizan funciones materialmente legislativas son la Unidad de Legislación Tributaria ${ }^{62}$ y la Dirección General de Legislación Aduanera y Comercio Exterior. ${ }^{63}$

\section{Competencia materialmente legislativa de la Administración General de Aduanas}

De acuerdo con lo señalado en el artículo 19 del Reglamento Interior del Servicio de Administración Tributaria, la Administración General de Aduanas también tiene facultades materialmente legislativas, que son las siguientes:

V. Establecer las estrategias, lineamientos y directrices que deben seguir las unidades administrativas que le sean adscritas y

62 Reglamento Interior de la Secretaría de Hacienda y Crédito Público, artículo 50.

63 Ibidem, artículo 52. 
las aduanas, respecto de normas de operación, despacho aduanero, comprobación del cumplimiento de las obligaciones fiscales y aduaneras, embargo precautorio, retención de mercancías, suspensión de libre circulación, procedimientos aduaneros que deriven del ejercicio de facultades de comprobación, verificación de la debida determinación y pago de impuestos, derechos, aprovechamientos y sus accesorios de carácter federal que se generen por la entrada y salida de mercancías del territorio nacional, así como del cumplimiento de las regulaciones y restricciones no arancelarias, inclusive en materia de normas oficiales mexicanas y comprobación del cumplimiento de los requisitos y obligaciones inherentes a la concesión, autorización, registro o patente otorgada por esta Administración General;

VII. Establecer estrategias o lineamientos para la operación de las áreas de servicios aduanales, respecto a la entrada y salida del territorio nacional de mercancías y medios de transporte, del despacho aduanero, los hechos y actos que deriven de éste o de dicha entrada o salida, así como de la vigilancia del cumplimiento de las obligaciones respectivas;

VIII. Establecer las estrategias o lineamientos para el control, vigilancia y seguridad de los recintos fiscales y fiscalizados concesionados, autorizados y estratégicos; de las mercancías de comercio exterior en ellos depositados; la circulación de vehículos dentro de dichos recintos, las operaciones de carga, descarga y manejo de dichas mercancías, así como, en coordinación con otras dependencias y entidades competentes de la Administración Pública Federal, para el control, vigilancia y seguridad sobre la entrada y salida de mercancías y personas en los aeropuertos, puertos marítimos y terminales ferroviarias o de autotransporte de carga y pasajeros autorizados para el tráfico internacional y en forma exclusiva en las aduanas, recintos fiscales, fiscalizados concesionados, autorizados y estratégicos, secciones aduaneras, garitas y puntos de revisión aduaneros;

IX. Establecer estrategias o lineamientos en materia de la recuperación de los depósitos en cuenta aduanera, efectuados por contribuyentes ante instituciones de crédito y casas de bolsa autorizadas para estos efectos y normar la operación de las disposiciones sobre recaudación, cobro coactivo, imposición de sanciones, 
contabilidad de ingresos y movimiento de fondos, en las materias a que se refiere el presente artículo;

XVIII. Emitir las disposiciones generales para la obtención de patentes de agente aduanal y autorizaciones de mandatario de agente aduanal y dictaminador aduanero, así como las convocatorias para la obtención de patentes de agente aduanal;

\title{
V. OBLIGACIONES DE LOS AGENTES ADUANALES DE ACEPTAR LA VISITA
}

Una de las obligaciones más importantes en esta materia es la señalada en el artículo 162, fracción IX, de la Ley Aduanera, que expresamente obliga a los agentes aduanales a aceptar las visitas que ordene la autoridad aduanera para comprobar que el agente aduanal cumple con su obligaciones, así como para que la autoridad administrativa en materia aduanera pueda realizar investigaciones determinadas.

Cabe señalar que la Ley no le otorga competencia expresa a la autoridad para hacer visitas domiciliarias de verificación a los agentes aduanales respecto de su patente. Lo que sí hace y puede hacer es solicitarle información. La visita domiciliaria es en su calidad de contribuyente.

De lo anterior se puede afirmar que los agentes aduanales están sujetos a las facultades de comprobación de las autoridades aduanales; en la actualidad existe una propuesta de modificación al artículo 42, fracción V, del Código Fiscal de la Federación.

\author{
VI. LA GANGELACIÓN DE LA PATENTE Y SU RELACIÓN \\ GON LOS DEREGHOS Y OBLIGAGIONES DEL AGENTE ADUANAL
}

\section{Aspectos generales}

De acuerdo con las diferentes leyes vigentes, la autoridad administrativa puede ordenar la verificación, la supervisión o la inspec- 
ción ${ }^{64}$ de bienes, personas, vehículos, documentos, establecimientos, etcétera, "con objeto de comprobar el cumplimiento de las disposiciones legales" 65 y/o reglamentarias.

En ese sentido, la siguiente tesis deja en claro los diferentes momentos en los cuales las autoridades realizan la vigilancia de las obligaciones de diferentes actores en el despacho aduanero, en el cual se encuentran también los agentes aduanales.

El Segundo Tribunal Colegiado en Materia Administrativa del Cuarto Circuito explica que:

El despacho aduanero es el marco de referencia dentro del cual se ubican los diversos trámites tanto fácticos como legales y técnicos que deben realizarse para la entrada de las mercancías al territorio nacional, entre los cuales se encuentra el pedimento, el reconocimiento aduanero, el segundo reconocimiento, la verificación de mercancías en transporte, la toma de muestras y su análisis por la autoridad aduanera competente, así como el desahogo de las diferencias legales o fácticas que surjan entre la autoridad aduanera y el importador o sus representantes. Ahora bien, si por una parte, conforme al artículo 46 de la Ley Aduanera, de la revisión de documentos presentados para el despacho de las mercancías, la autoridad se percata de alguna irregularidad, debe asentarla en escrito o acta circunstanciada, conforme al procedimiento que corresponda de acuerdo con los preceptos 150 a 153 de la referida ley, en los que deben constar los hechos u omisiones observados por la autoridad y las irregularidades apreciadas y, por otra, en términos del numeral 41 de la citada ley, la representación otorgada a los agentes aduanales para actuar en nombre del importador se limita a la realización ante las autoridades aduanales, de los trámites administrativos y de aquellos relacionados con el

64 Por ejemplo, el artículo 43 de la Ley Aduanera.

65 El artículo 69 de la Ley Federal de Procedimiento Administrativo establece que "las dependencias podrán, de conformidad con las disposiciones aplicables, verificar bienes, personas y vehículos de transporte con el objeto de comprobar el cumplimiento de las disposiciones legales, para lo cual se deberán cumplir, en lo conducente, las formalidades previstas para las visitas de verificación". 
desahogo de las diferencias legales o fácticas que surjan entre la autoridad y el importador o su representante, relativos a la entrada de mercancías al territorio nacional; luego, las notificaciones que se refieran a observaciones por el incumplimiento u omisión de las formalidades relativas al despacho aduanero de mercancías o del acta levantada con motivo de alguna irregularidad detectada en el reconocimiento aduanero en el caso de mercancías que no son de difícil identificación, deberán entenderse con el agente aduanal, en tanto que cualquier error o vicio que en tal aspecto se advierta únicamente repercute en el ámbito de su actuación y representación dentro del aludido despacho, sin afectar los intereses del importador, y atendiendo al párrafo final del dispositivo legal citado en último término, las autoridades aduaneras únicamente tienen obligación de notificar a los importadores y exportadores, además de a su representante — agente aduanal—, de cualquier procedimiento que se inicie con posterioridad al despacho aduanero de manera independiente y autónoma, pues en tal caso ya no existe la representación legal del agente y sí una responsabilidad solidaria en su actuar. ${ }^{66}$

En relación con lo anterior, cabe destacar que el artículo 16, párrafo 16, de la Constitución establece que "la autoridad administrativa podrá practicar visitas domiciliarias únicamente para cerciorarse de que se han cumplido los reglamentos sanitarios y de policía...".

Asimismo,

De conformidad con el artículo 152 de la Ley Aduanera las autoridades darán a conocer mediante escrito o acta circunstanciada las inconsistencias que impliquen la omisión de contribuciones, cuotas compensatorias y, en su caso, la imposición de sanciones, determinadas con motivo del reconocimiento aduanero, del segundo reconocimiento, de la verificación de mercancías en trans-

66 Tesis aislada IV.2o.A.203A, Segundo Tribunal Colegiado en Materia Administrativa del Cuarto Circuito, Semanario fudicial de la Federación y su Gaceta, Novena Época, t. XXVI, agosto de 2007, p. 1537. 
porte, de la revisión de los documentos presentados durante el despacho o del ejercicio de las facultades de comprobación, y deberá señalarse al interesado que cuenta con un plazo de diez días para ofrecer las pruebas y alegatos que a su derecho convengan. Por tanto, si a través de un parte de irregularidades un subadministrador comunica al administrador de la aduana que el agente aduanal presentó al módulo de selección automatizado para su despacho un pedimento de importación "sin estar debidamente firmado", por lo que se tipificó una infracción prevista por la ley de la materia, contando con un plazo de diez días para presentar las pruebas y alegatos que a su derecho convengan, es claro que el documento de referencia al no estar dirigido al presunto infractor, ni la autoridad señalar con precisión que a través de dicho parte de irregularidades le daba a conocer los hechos u omisiones conocidos de la revisión del pedimento y que contaba con el aludido plazo para defenderse, aun cuando en la parte inferior del propio documento se haya hecho constar que un dependiente del agente aduanal firmó de enterado acerca de la comunicación interna que tenían aquellos servidores públicos, no puede concluirse que la autoridad emisora del acto cumplió con la obligación que a su cargo establece el citado artículo 152, dado que se obligaría al particular a defenderse a base de hacer conjeturas sobre que a él se dirigió el documento de que se trata. Además, aunque es cierto que corresponde al gobernado desvirtuar los hechos u omisiones conocidos de la revisión de los documentos presentados durante el despacho, y no a las autoridades aduaneras, sin embargo, no debe desatenderse que para que el agente aduanal pueda ofrecer pruebas y formular alegatos con aquel propósito, es menester que la autoridad informe en forma clara y precisa al interesado las irregularidades conocidas con motivo de la revisión, ya que por la forma confusa en que el parte de irregularidades fue redactado no se tiene pleno conocimiento que a partir de su notificación comenzará a correr el plazo de diez días para presentar pruebas y alegatos, o si tendrá que esperar a que el administrador de la aduana haga de su conocimiento tales circunstancias en documento por separado. ${ }^{67}$

67 Tesis aislada III.4o.A.2A, Cuarto Tribunal Colegiado en Materia Ad- 
Por ello, la finalidad de toda norma jurídica es regular conductas con el objeto de proteger los intereses de la sociedad, y para cumplir con esa finalidad y con ese objeto es que se ha establecido la figura de la visita domiciliaria, que puede ser de verificación, de revisión o de inspección.

De acuerdo con lo establecido por las normativas en materia aduanera, la verificación o inspección administrativa de la actividad que realiza el agente aduanal puede extenderse tanto a las obligaciones señaladas en el artículo 162 de la Ley Aduanera, como a las causas de cancelación de la patente, lo cual es incongruente con la propia finalidad de la visita de inspección, ya que se extienden las obligaciones del agente aduanal en un artículo que no tiene esa denominación.

En ese sentido, la Primera Sala de la Suprema Corte de Justicia de la Nación señaló que

...las funciones desarrolladas al amparo de la... patente no pueden considerarse como una actividad económica que realiza un particular como si fuese una empresa cuya actividad pone en marcha la economía nacional, en virtud de que se trata de una actividad que auxilia las labores del Estado...; es decir, el servicio que desempeñan los agentes aduanales, al ser una actividad privada de interés público, debe sujetarse a una estricta reglamentación y vigilancia.

En realidad, en la práctica, son las causas de cancelación las que verifica la autoridad aduanera, en virtud de que las obligaciones del artículo 162 no se verifican, o si se llegaran a verificar éstas no tienen sanción.

El hecho de que la autoridad no aplique sanciones al incumplimiento de lo dispuesto en el artículo 162, aunque efectivamente no constituyen causales de cancelación, sí pueden generar una

ministrativa del Tercer Circuito, Semanario Fudicial de la Federación y su Gaceta, Novena Época, t. XXV, febrero de 2007, p. 1840. 
sanción como la inhabilitación, en el caso de las fracciones II y III del numeral $162 .{ }^{6}$

La verificación que realiza la autoridad aduanera puede efectuarla en un procedimiento tradicional o por medios electrónicos, en virtud de que la actividad del agente se realiza tanto presencial como electrónicamente.

\section{Verificación de las obligaciones en forma tradicional}

1) En los trámites o gestiones aduanales, debe actuar siempre con su carácter de agente aduanal.

2) Rendir el dictamen técnico cuando se lo solicite la autoridad competente. En ese sentido, la tesis aislada IV.2o.A.179 A del Segundo Tribunal Colegiado en Materia Administrativa del Cuarto Circuito es ilustrativa, a saber:

Conforme a los artículos 43, 46, 144 y 150 a 153 de la Ley Aduanera, cuando las autoridades aduaneras con motivo de la revisión de documentos presentados para el despacho de las mercancías, del reconocimiento aduanero, del segundo reconocimiento o de la verificación de mercancías en transporte adviertan alguna irregularidad deberán levantar el acta circunstanciada respectiva, haciendo constar los hechos u omisiones observados y determinarán, además, el valor y clasificación arancelaria de tales mercancías, siendo estos actos administrativos de suma importancia, ya que en ellos descansa la estimación de aquéllas y su ubicación en alguna de las fracciones arancelarias previstas en la tarifa del impuesto general de importación o exportación; en tal virtud, la interpretación sistemática del artículo 144, fracción XIV, segundo párrafo, de la referida ley, en relación con las disposiciones que regulan el procedimiento en cita, lleva a la conclusión de que, al disponer que es facultad de la Secretaría de Hacienda y Crédito Público el determinar la naturaleza, características, clasificación arancelaria, origen y valor de las mercancías sujetas al régimen

68 Véase el artículo 164 de la Ley Aduanera. 
de importación o exportación establece la obligación a cargo de la aludida autoridad de apoyar su motivación en un dictamen técnico que lo sustente, pues la referida determinación requiere conocimientos especializados, necesarios para determinar el tipo, naturaleza, características y percepción comercial de las mercancías. Por tanto, se concluye que el numeral 144, fracción XIV, segundo párrafo, citado, no establece discrecionalidad alguna en el sentido de que dicha clasificación pueda o no estar apoyada en el dictamen de un experto, y que el término "podrá" ahí empleado, está expresado en su sentido gramatical de tener expedita facultad o potestad de hacer una cosa, refiriéndose en este caso a la libertad de elegir, para requerir el dictamen técnico en cita, ya sea a un agente aduanal, a un dictaminador aduanero o a cualquier perito en la materia, mas no exime a la autoridad de la obligación de recabarlo, porque en él debe sustentarse la clasificación arancelaria, pues debe especificar la metodología científica empleada en relación con el resultado obtenido, puntualizando los elementos que se tomaron en cuenta, así como los razonamientos técnicos realizados para determinar el valor en aduanas de las mercancías y las cargas tributarias que originan, lo que le aporta a esa clasificación la debida fundamentación y motivación que exige el artículo 237 del Código Fiscal de la Federación, vigente hasta el 31 de diciembre de 2005.

3) Cumplir el encargo que se le hubiera conferido, por lo que no podrá transferirlo ni endosar documentos que estén a su favor o a su nombre, sin la autorización expresa y por escrito de quien lo otorgó.

4) Declarar, bajo protesta de decir verdad, el nombre y domicilio fiscal del destinatario o del remitente de las mercancías, la clave del Registro Federal de Contribuyentes de aquéllos y el propio, la naturaleza y características de las mercancías y los demás datos relativos a la operación de comercio exterior en que intervenga, en las formas oficiales y documentos en que se requieran o, en su caso, en el sistema mecanizado.

En este caso concreto, la Segunda Sala de la Suprema Corte de Justicia de la Nación señaló: 
El citado reconocimiento tiene como fin que la autoridad aduanera, en uso de sus facultades de comprobación, establezca si lo declarado por el particular y su agente aduanal en el pedimento concuerda fehacientemente con la mercancía objeto de la importación o exportación; determine los impuestos y las cuotas compensatorias correspondientes y, entre otras cuestiones, verifique los permisos a que estén sujetas las mercancías objeto del comercio exterior. Por otra parte, del artículo 43 de la Ley Aduanera se advierte el principio de inmediatez que debe regir en dicha materia tratándose del reconocimiento aduanero cuando no exista embargo de mercancías, pues señala que si el resultado del mecanismo de selección automatizado es afirmativo, entonces se efectuará el reconocimiento aduanero ante quien presente las mercancías en el recinto fiscal. En ese tenor, de la interpretación sistemática de los artículos 43, 46 y 152 de la citada Ley, y a efecto de no dejar en estado de inseguridad al interesado ni permitir que la autoridad aduanera arbitrariamente determine el momento de levantar el acta circunstanciada, se concluye que éste debe ser cuando al realizarse el acto material del reconocimiento se advierta alguna irregularidad ante quien presenta las mercancías para su despacho aduanal. ${ }^{69}$

En otro caso determinó que:

El artículo 160, fracción VI, párrafo tercero de la Ley Aduanera prevé que se entenderá que el agente aduanal es notificado personalmente cuando la notificación de los actos derivados del reconocimiento aduanero y segundo reconocimiento se efectúe con cualquiera de sus empleados, dependientes autorizados o mandatarios. En tal virtud, para determinar con precisión cuáles son los actos sobre los que aquéllos están en posibilidad de imponerse legalmente y que surtirán efectos conforme a la señalada disposición, es menester acudir a los preceptos 43 a 46 de la Ley Aduanera, así como 65 y 66 de su reglamento, que regulan el

69 Tesis de jurisprudencia 2a./J.39/2006, Segunda Sala, Semanario fudicial de la Federación y su Gaceta, Novena Época, t. XXIII, abril de 2006, p. 175. 
trámite del reconocimiento de mercancías, de cuyo contenido se advierte que sólo pueden ser aquellos en los que con motivo de la inspección física, técnica y legal de las mercancías presentadas para su despacho, deba comprobarse lo siguiente: a) la veracidad de lo declarado respecto de las unidades de medida señaladas en las tarifas de las leyes de los impuestos generales de importación o exportación; b) el número de piezas; c) el volumen; d) otros datos para cuantificar las mercancías; y, e) su descripción, naturaleza, estado, origen y demás características, lo que implica que la resolución determinante de un crédito fiscal a cargo del agente aduanal, emitida con motivo de un procedimiento administrativo en materia aduanera, no puede considerarse como un acto derivado del reconocimiento aduanero de mercancías, ya que si bien es cierto que aquélla de alguna manera puede estar vinculada con éste, también lo es que no forma parte de los actos que derivan directamente de él, ya que es posible que dicho fallo sea emitido con motivo de la verificación de mercancías en transporte, de la revisión de documentos presentados durante el despacho o del ejercicio de facultades de comprobación. Por tanto, la notificación de la mencionada resolución determinante no puede considerarse personal si se practica en términos del citado artículo 160, fracción VI, párrafo tercero, verbigracia, por conducto de un autorizado del agente aduanal, pues, se reitera, no se trata de un acto derivado del reconocimiento aduanero y, por ende, tal notificación es ineficaz e ilegal para efectos del cómputo de los plazos para la interposición de los medios de defensa que correspondan. ${ }^{70}$

\section{Otro criterio señala que}

La Segunda Sala de la Suprema Corte de Justicia de la Nación, al resolver la contradicción de tesis 53/2004-SS, que dio origen a la jurisprudencia 2a./J. 175/2004, publicada en el Semanario Judicial de la Federación y su Gaceta, Novena Época, tomo XX,

70 Tesis aislada IV.2o.A.253A, Segundo Tribunal Colegiado en Materia Administrativa del Cuarto Circuito, Semanario fudicial de la Federación y su Gaceta, Novena Época, t. XXIX, junio de 2009, p. 1043. 
diciembre de 2004, página 385, de rubro: "AGENTE ADUANAL. Si SÓLO A ÉL Y NO AL IMPORTADOR SE NOTIFICÓ EL CRÉDITO FISCAL POR OMISIÓN DE CONTRIBUCIONES, NO PUEDE INICIAR PARA ÉSTE EL CÓMPUTO DEL PLAZO PARA SU IMPUGNACIÓN", estimó que quien está facultado para impugnar la resolución por omisión de contribuciones es el importador y no el agente aduanal, ya que éste sólo tiene el carácter de representante legal de aquél por lo que hace a todos los actos y formalidades relativos a la entrada de mercancías al territorio nacional, pero no para interponer recurso alguno en su nombre y representación. En esa tesitura, y tomando en cuenta además que la referida Segunda Sala ha establecido que el plazo de cuatro meses previsto por el artículo 152 de la Ley Aduanera, vigente hasta el 2 de febrero de 2006, para que la autoridad competente emita la resolución definitiva en el procedimiento administrativo en la materia, debe computarse a partir de la notificación del escrito o acta circunstanciada de los hechos u omisiones que impliquen la omisión de contribuciones, cuotas compensatorias y, en su caso, la imposición de sanciones que al respecto se levante, como se advierte de la tesis 2a./J. 206/2006, publicada en el citado medio de difusión y época, tomo XXV, enero de 2007, página 490, de rubro: “AUTORIDADES ADUANERAS. EL PLAZO DE 4 MESES PREVISTO EN EL ARTÍCULO 152 DE LA LEY ADUANERA VIGENTE HASTA EL 2 DE FEBRERO DE 2006, PARA QUE EMITAN LA RESOLUCIÓN DEFINITIVA EN EL PROGEDIMIENTO ADMINISTRATIVO QUE EN ESE NUMERAL SE ESTABLECE, DEBE EMPEZAR A CONTARSE A PARTIR DE LA NOTIFICACIÓN DEL AGTA GIRCUNSTANGIADA QUE AL RESPECTO SE LEVANTE", en el supuesto de que la autoridad primero notifique al importador el mencionado escrito o acta circunstanciada y después al agente aduanal, el plazo de referencia debe computarse a partir de la fecha en que hizo saber a aquél los hechos u omisiones advertidos, por ser a quien afecta la resolución que en su momento dicte la autoridad. ${ }^{71}$

71 Tesis aislada I.7o.A.527A, Séptimo Tribunal Colegiado en Materia Administrativa del Primer Circuito, Semanario fudicial de la Federación y su Gaceta, Novena Época, t. XXVI, agosto de 2007, p. 1782. 
5) Solicitar la autorización de las autoridades aduaneras para suspender sus actividades, en los casos previstos en la Ley.

6) Manifestar en el pedimento o en el aviso consolidado, el número de candado oficial utilizado en los vehículos o medios de transporte que contengan las mercancías cuyo despacho promuevan.

7) Presentar aviso al Servicio de Administración Tributaria dentro de los quince días siguientes a aquel en que constituya una sociedad de las previstas en la fracción II del artículo 163 de la Ley.

8) Acreditar, en su caso, ante cada aduana en la que ejerza la patente al menos a un mandatario autorizado por la autoridad aduanera. Asimismo, deberá usar el gafete de identificación personal en los recintos fiscales en que actúe; obligación que también deben cumplir sus empleados o dependientes autorizados y sus mandatarios. ${ }^{72}$

9) Ocuparse, en su aduana de adscripción, por lo menos, del $15 \%$ de las operaciones de importación y exportación con un valor que no rebase al que, mediante reglas, determine el Servicio de Administración Tributaria.

10) Contravenir lo dispuesto en el artículo 163, fracción II. Es decir, constituir sociedades integradas por mexicanos para facilitar la prestación de sus servicios. La sociedad y sus socios, salvo los propios agentes aduanales, no adquirirán derecho alguno sobre la patente ni disfrutarán de los que la ley confiere a estos últimos.

11) Ser condenado en sentencia definitiva por haber participado en la comisión de delitos fiscales o de otros delitos intencionales que ameriten pena corporal.

12) Permitir el uso por cualquier tercero de alguno de los derechos consignados en la patente o de la patente misma, y que con dicho uso obtenga un lucro o explotación de la patente.

72 Artículos 160, fracción VI, y 17 de la Ley Aduanera. 
13) Tratándose de los regímenes aduaneros temporales, de depósito fiscal y de tránsito de mercancías, declarar con inexactitud alguno de los datos a que se refiere el primer párrafo de la fracción II de este artículo, siempre que con los datos aportados, excluida la liquidación provisional a que se refieren los artículos 127, fracción II, y 131, fracción II de la Ley, de haberse destinado la mercancía de que se trate al régimen de importación definitiva, se dé alguno de los siguientes supuestos:

a) La omisión exceda de $\$ 228,290.00$ y del $10 \%$ de los impuestos al comercio exterior, derechos y, en su caso, cuotas compensatorias causadas.

b) Efectuar los trámites del despacho sin el permiso o sin contar con la asignación del cupo de las autoridades competentes, cuando se requieran, o sin realizar el descargo total o parcial sobre el permiso o cupo antes de activar el mecanismo de selección automatizado.

c) Se trate de mercancías de importación o exportación prohibida.

14) Carecer por tercera ocasión de bienes suficientes para cubrir créditos fiscales que hayan quedado firmes y que para su cobro se haya seguido el procedimiento administrativo de ejecución en los cinco años anteriores.

15) Transmitir bajo cualquier título, el uso o goce de la patente o de los derechos consignados en la misma.

16) Efectuar los trámites del despacho aduanero a un importador o exportador que no se encuentre inscrito en el padrón de importadores y, en su caso, en el padrón de importadores de sectores específicos o en el padrón de exportadores sectorial, cuando se requiera de dicha inscripción.

17) Se abstengan de cumplir con los requerimientos que les formule la Secretaría en términos de la Ley Federal para la Prevención e Identificación de Operaciones con Recursos de Procedencia Ilícita. 
18) Incumplan con cualquiera de las obligaciones establecidas en el artículo 18 de la Ley antes indicada, que señala lo siguiente:

Artículo 18. Quienes realicen las actividades vulnerables a que se refiere el artículo anterior tendrán las obligaciones siguientes:

I. Identificar a los clientes y usuarios con quienes realicen las propias actividades sujetas a supervisión y verificar su identidad basándose en credenciales o documentación oficial, así como recabar copia de la documentación;

II. Para los casos en que se establezca una relación de negocios, se solicitará al cliente o usuario la información sobre su actividad u ocupación, basándose, entre otros, en los avisos de inscripción y actualización de actividades presentados para efectos del Registro Federal de Contribuyentes;

III. Solicitar al cliente o usuario que participe en actividades vulnerables información acerca de si tiene conocimiento de la existencia del dueño beneficiario y, en su caso, exhiban documentación oficial que permita identificarlo, si ésta obrare en su poder; en caso contrario, declarará que no cuenta con ella;

IV. Custodiar, proteger, resguardar y evitar la destrucción u ocultamiento de la información y documentación que sirva de soporte a la actividad vulnerable, así como la que identifique a sus clientes o usuarios.

La información y documentación a que se refiere el párrafo anterior deberá conservarse de manera física o electrónica, por un plazo de cinco años contado a partir de la fecha de realización de la actividad vulnerable, salvo que las leyes de la materia de las entidades federativas establezcan un plazo diferente;

V. Brindar las facilidades necesarias para que se lleven a cabo las visitas de verificación en los términos de esta Ley, y

VI. Presentar los avisos en la Secretaría en los tiempos y bajo la forma prevista en esta Ley.

19) Incumplan con la obligación de presentar en tiempo los avisos a que se refiere el artículo 17 de la Ley. 
La sanción prevista en la fracción VI del artículo 18 será aplicable cuando la presentación del aviso se realice dentro de los treinta días siguientes a la fecha en que debió haber sido presentado. En caso de que la extemporaneidad u omisión exceda ese plazo, se aplicará la sanción prevista para el caso de omisión en el artículo 55 de la Ley.

20) Incumplan con la obligación de presentar los avisos sin reunir los requisitos a que se refiere el artículo 24 de la Ley.

Artículo 24. La presentación de los avisos se llevará a cabo a través de los medios electrónicos y en el formato oficial que establezca la Secretaría.

Dichos avisos contendrán respecto del acto u operación relacionados con la actividad vulnerable que se informe, lo siguiente:

I. Datos generales de quien realice la actividad vulnerable;

II. Datos generales del cliente, usuarios o del beneficiario controlador, y la información sobre su actividad u ocupación de conformidad con el artículo 18 fracción II de esta Ley, y

III. Descripción general de la actividad vulnerable sobre la cual se dé aviso.

A los notarios y corredores públicos se les tendrán por cumplidas las obligaciones de presentar los avisos correspondientes mediante el sistema electrónico por el que informen o presenten las declaraciones y avisos a que se refieren las disposiciones fiscales federales.

21) Incumplan con las obligaciones que impone el artículo 33 de la Ley.

22) Omitan presentar los avisos a que se refiere el artículo 17 de la Ley.

Artículo 17. Para efectos de esta Ley se entenderán actividades vulnerables y, por tanto, objeto de identificación en términos del artículo siguiente, las que a continuación se enlistan:

XIV. La prestación de servicios de comercio exterior como agente o apoderado aduanal, mediante autorización otorgada por 
la Secretaría de Hacienda y Crédito Público, para promover por cuenta ajena, el despacho de mercancías, en los diferentes regímenes aduaneros previstos en la Ley Aduanera, de las siguientes mercancías:

a) Vehículos terrestres, aéreos y marítimos, nuevos y usados, cualquiera que sea el valor de los bienes;

b) Máquinas para juegos de apuesta y sorteos, nuevas y usadas, cualquiera que sea el valor de los bienes;

c) Equipos y materiales para la elaboración de tarjetas de pago, cualquiera que sea el valor de los bienes;

d) Joyas, relojes, piedras preciosas y metales preciosos, cuyo valor individual sea igual o superior al equivalente a cuatrocientas ochenta y cinco veces el salario mínimo vigente en el Distrito Federal;

e) Obras de arte, cuyo valor individual sea igual o superior al equivalente a cuatro mil ochocientas quince veces el salario mínimo vigente en el Distrito Federal;

f) Materiales de resistencia balística para la prestación de servicios de blindaje de vehículos, cualquiera que sea el valor de los bienes.

Las actividades anteriores serán objeto de aviso en todos los casos antes señalados, atendiendo lo establecido en el artículo 19 de la presente Ley.

23) Participen en cualquiera de los actos u operaciones prohibidos por el artículo 32 de la Ley.

\section{Auditorías electrónicas}

Se refiere a la facultad que tiene la autoridad para comprobar, por medios tecnológicos, el cumplimiento de los requisitos técnicos que señalan las leyes. 


\section{AUTORIDADES COMPETENTES \\ EN MATERIA DE VERIFICACIÓN}

\section{Secretaría de Hacienda y Crédito Público}

Las atribuciones de la Secretaría de Hacienda y Crédito Público en materia de vigilancia se encuentran señaladas en las fracciones XI, XII y XIII del artículo 31 de la Ley Orgánica de la Administración Pública Federal, que indica:

Artículo 31. A la Secretaría de Hacienda y Crédito Público corresponde el despacho de los siguientes asuntos:

XI. Cobrar los impuestos, contribuciones de mejoras, derechos, productos y aprovechamientos federales en los términos de las leyes aplicables y vigilar y asegurar el cumplimiento de las disposiciones fiscales;

XII. Organizar y dirigir los servicios aduanales y de inspección;

XIII. Representar el interés de la Federación en controversias fiscales.

Sin duda alguna, la fracción XI tiene un contenido meramente fiscal, pero recordemos que uno de los principales intereses de todo gobierno en cuanto al ingreso y la salida de mercancías son los impuestos que se generan con motivo de esta actividad de comercio exterior, razón por la cual la materia fiscal está íntimamente ligada a la aduanera y no se comprende la una sin la otra, a tal grado que el legislador entiende que es a la Secretaría de Hacienda y Crédito Público a la que le compete, por tanto, organizar y dirigir los servicios aduanales, y no sólo eso, sino la inspección de los mismos.

La inspección, en el sentido ya señalado, entendida como una forma de vigilar las actuaciones de los sujetos que llevan a cabo los procedimientos aduaneros necesarios para el ingreso y salida de mercancías del territorio nacional. 
La fracción XIII establece una función propiamente contenciosa para representar a la Federación en caso de controversias fiscales que, como ya hemos explicado, involucran directamente a la actividad aduanal por su propia naturaleza impositiva.

En el artículo 144 de la Ley Aduanera están señaladas las facultades de la Secretaría de Hacienda y Crédito Público en materia de vigilancia. Son las siguientes:

Artículo 144. La Secretaría tendrá, además de las conferidas por el Código Fiscal de la Federación y por otras leyes, las siguientes facultades:

II. Comprobar que la importación y exportación de mercancías, la exactitud de los datos contenidos en los pedimentos, declaraciones o manifestaciones, el pago correcto de las contribuciones y aprovechamientos y el cumplimiento de las regulaciones y restricciones no arancelarias, se realicen conforme a lo establecido en esta Ley.

III. Requerir de los contribuyentes, responsables solidarios y terceros, la información y documentación relacionada con las obligaciones y requisitos que establecen las disposiciones fiscales y aduaneras, empleando, en su caso, el sistema electrónico que se disponga...

V. Cerciorarse que en el despacho aduanero los importadores, los exportadores y los agentes aduanales, cumplan los requisitos establecidos por esta Ley y por las reglas que dicte el Servicio de Administración Tributaria, respecto del equipo para promover el despacho electrónico.

VI. Practicar el reconocimiento aduanero de las mercancías en los recintos fiscales y fiscalizados o, a petición del contribuyente, en su domicilio o en las dependencias, bodegas, instalaciones o establecimientos que señale, cuando se satisfagan los requisitos previstos en el Reglamento, así como conocer del dictamen aduanero a que se refiere el artículo 43 de esta Ley, y revisar los dictámenes formulados por los dictaminadores aduaneros en los términos del artículo 175. 
VII. Verificar que las mercancías por cuya importación fue concedido algún estímulo fiscal, franquicia, exención o reducción de impuestos o se haya eximido del cumplimiento de una regulación o restricción no arancelaria, estén destinadas al propósito para el que se otorgó, se encuentren en los lugares señalados al efecto y sean usadas por las personas a quienes fue concedido, en los casos en que el beneficio se haya otorgado en razón de dichos requisitos o de alguno de ellos...

IX. Inspeccionar y vigilar permanentemente en forma exclusiva, el manejo, transporte o tenencia de las mercancías en los recintos fiscales y fiscalizados, para lo cual podrá apoyarse de los sistemas, equipos tecnológicos, o cualquier otro medio o servicio con que se cuente, incluso el dictamen aduanero a que se refiere el artículo 43 de esta Ley...

XI. Verificar en forma exclusiva durante su transporte, la legal importación o tenencia de mercancías de procedencia extranjera en todo el territorio nacional, para lo cual podrá apoyarse de los sistemas, equipos tecnológicos, cualquier otro medio o servicio con que se cuente, incluso en el dictamen aduanero a que se refiere el artículo 43 de esta Ley...

XVI. Comprobar la comisión de infracciones e imponer las sanciones que correspondan...

XXX. Ordenar y practicar el embargo precautorio en los términos del Código Fiscal de la Federación, de las cantidades en efectivo, en cheques nacionales o extranjeros, órdenes de pago o cualquier otro documento por cobrar o una combinación de ellos, superiores al equivalente en la moneda o monedas de que se trate, a diez mil dólares de los Estados Unidos de América, cuando se omita declararlas a las autoridades aduaneras, al entrar o salir del territorio nacional, conforme a lo dispuesto en el artículo 9o. de esta Ley...

XXXII. Verificar y supervisar los servicios autorizados que facilitan el reconocimiento aduanero empleando tecnología no intrusiva.

Además de las anteriores, destaca, en el Código Fiscal de la Federación, en materia de vigilancia, la siguiente norma: 
Artículo 42. Las autoridades fiscales a fin de comprobar que los contribuyentes, los responsables solidarios o los terceros con ellos relacionados han cumplido con las disposiciones fiscales y, en su caso, determinar las contribuciones omitidas o los créditos fiscales, así como para comprobar la comisión de delitos fiscales y para proporcionar información a otras autoridades fiscales, estarán facultadas para:

II. Requerir a los contribuyentes, responsables solidarios o terceros con ellos relacionados, para que exhiban en su domicilio, establecimientos, en las oficinas de las propias autoridades o dentro del buzón tributario, dependiendo de la forma en que se efectuó el requerimiento, la contabilidad, así como que proporcionen los datos, otros documentos o informes que se les requieran a efecto de llevar a cabo su revisión.

V. Practicar visitas domiciliarias a los contribuyentes, a fin de verificar el cumplimiento de las obligaciones fiscales en materia de expedición de comprobantes fiscales digitales por Internet y de presentación de solicitudes o avisos en materia del registro federal de contribuyentes; el cumplimiento de obligaciones en materia aduanera derivadas de autorizaciones o concesiones o de cualquier padrón o registro establecidos en las disposiciones relativas a dicha materia; verificar que la operación de las máquinas, sistemas y registros electrónicos, que estén obligados a llevar los contribuyentes, se realice conforme lo establecen las disposiciones fiscales; así como para solicitar la exhibición de la documentación o los comprobantes que amparen la legal propiedad, posesión, estancia, tenencia o importación de las mercancías, y verificar que los envases o recipientes que contengan bebidas alcohólicas cuenten con el marbete o precinto correspondiente o, en su caso, que los envases que contenían dichas bebidas hayan sido destruidos y verificar que las cajetillas de cigarros para su venta en México contengan impreso el código de seguridad o, en su caso, que éste sea auténtico, de conformidad con el procedimiento previsto en el artículo 49 de este Código.

También destaca el artículo 152 de la Ley Aduanera, que señala: 
Artículo 152. En los casos en que con motivo del reconocimiento aduanero, de la verificación de mercancías en transporte, de la revisión de los documentos presentados durante el despacho o del ejercicio de las facultades de comprobación, en que proceda la determinación de contribuciones omitidas, aprovechamientos y, en su caso, la imposición de sanciones y no sea aplicable el artículo 151 de esta Ley, las autoridades aduaneras procederán a su determinación, sin necesidad de sustanciar el procedimiento establecido en el artículo 150 de esta Ley.

Tratándose de mercancías de difícil identificación, que requiera la toma de muestras a fin de identificar su composición cualitativa o cuantitativa, uso, proceso de obtención o características físicas, se realizará dicha toma de acuerdo con el procedimiento que al efecto prevé el reglamento, para su análisis y dictamen conducentes.

Una vez obtenido el dictamen correspondiente, resultado del análisis practicado a las muestras de mercancías de difícil identificación, se notificarán al interesado mediante escrito o acta circunstanciada, los hechos u omisiones advertidos, dentro del plazo de seis meses contados a partir del acta de toma de muestras correspondientes, y se continuará el procedimiento conforme a lo establecido en el presente artículo.

Cuando no se requiera la toma de muestras para su identificación, la autoridad aduanera dará a conocer mediante escrito o acta circunstanciada, los hechos u omisiones que impliquen la omisión de contribuciones, cuotas compensatorias y, en su caso, la imposición de sanciones.

Dentro del escrito o acta circunstanciada levantada en los términos de los párrafos tercero y cuarto de este artículo, deberá señalarse que el interesado cuenta con un plazo de diez días hábiles, contados a partir del día siguiente a aquel en que surta efectos la notificación del escrito o acta, a fin de ofrecer las pruebas y formular los alegatos que a su derecho convenga.

El ofrecimiento, desahogo y valoración de las pruebas se hará de conformidad con lo dispuesto en los artículos 123 y 130 del Código Fiscal de la Federación. 
Las autoridades aduaneras emitirán resolución en un plazo que no excederá de cuatro meses, contados a partir del día siguiente a aquel en que se encuentre debidamente integrado el expediente. En caso de no emitirla, deberá poner de inmediato a disposición del interesado la mercancía de su propiedad.

Se entiende que el expediente se encuentra debidamente integrado cuando hayan vencido los plazos para la presentación de todos los escritos de pruebas y alegatos o, en caso de resultar procedente, la autoridad encargada de emitir la resolución haya llevado a cabo las diligencias necesarias para el desahogo de las pruebas ofrecidas por los promoventes.

En los demás casos la determinación del crédito fiscal se hará por la autoridad aduanera.

En el escrito o acta de inicio del procedimiento se deberá requerir al interesado para que señale domicilio para oír y recibir notificaciones, apercibido que de no señalar el domicilio, de señalar uno que no le corresponda a él o a su representante, de desocupar el domicilio señalado sin aviso a la autoridad competente o señalando un nuevo domicilio que no le corresponda a él o a su representante, de desaparecer después de iniciadas las facultades de comprobación o de oponerse a las diligencias de notificación de los actos relacionados con el procedimiento, negándose a firmar las actas que al efecto se levanten, las notificaciones que fueren personales se efectuarán por estrados, siempre que, en este último caso y tratándose del reconocimiento aduanero, o de la verificación de mercancías en transporte, se cuente con visto bueno del administrador de la aduana. Cuando proceda la imposición de sanciones, sin la determinación de contribuciones o cuotas compensatorias omitidas ni el embargo precautorio de mercancías, la autoridad aduanera determinará el crédito fiscal, sin necesidad de sustanciar el procedimiento establecido en este artículo y en el artículo 150 de la Ley, quedando a salvo los derechos del contribuyente mediante el recurso de revocación establecido en el Código Fiscal de la Federación. 
Este libro forma parte del acervo de la Biblioteca Jurídica Virtual del Instituto de Investigaciones Jurídicas de la UNAM

\section{Servicio de Administración Tributaria}

\section{A. Aspectos generales}

El artículo 1o. de la Ley del Servicio de Administración Tributaria establece:

Artículo 1o. El Servicio de Administración Tributaria, como órgano desconcentrado de la Secretaría de Hacienda y Crédito Público, tiene a su cargo el ejercicio de las facultades y el despacho de los asuntos que le encomiendan la Ley del Servicio de Administración Tributaria y los distintos ordenamientos legales aplicables, así como los reglamentos, decretos, acuerdos y órdenes del presidente de la República y los programas especiales y asuntos que el secretario de Hacienda y Crédito Público le encomiende ejecutar y coordinar en las materias de su competencia.

Por lo que respecta a su organización y en relación con la materia aduanera, el Servicio de Administración Tributaria (en adelante SAT) está integrado por una Junta de Gobierno, el jefe del SAT y las unidades administrativas centrales y regionales previstas en su Reglamento Interior.

De este modo, dicho órgano desconcentrado tiene facultades y atribuciones como autoridad en materia fiscal y aduanera, como lo veremos a continuación, con base en las siguientes disposiciones normativas.

Las atribuciones del jefe de SAT se encuentran en el artículo 8o. del Reglamento Interior del SAT, de las cuales destacan en materia aduanal las siguientes:

Artículo 8o. El jefe del Servicio de Administración Tributaria es la máxima autoridad administrativa de este órgano administrativo desconcentrado, a quien le corresponde originalmente el trámite y resolución de los asuntos de la competencia de dicho órgano y ejercerá, además de las facultades previstas en el artículo 14 de la Ley del Servicio de Administración Tributaria, las siguientes: 
$\mathrm{XV}$. Otorgar las autorizaciones previstas por las disposiciones fiscales y aduaneras;

XVII. Expedir los acuerdos por los que se deleguen facultades a los servidores públicos o a las unidades administrativas del Servicio de Administración Tributaria; se determinen la circunscripción territorial de las aduanas y las secciones aduaneras de las aduanas, subsedes de las administraciones desconcentradas de la Administración General de Auditoría de Comercio Exterior; se constituyan sedes de las unidades administrativas centrales fuera de la Ciudad de México y aquellos por los que se apruebe la ubicación de sus oficinas en el extranjero y designar a los servidores públicos adscritos a dichas oficinas;

XVIII. Proporcionar a las autoridades competentes de la Secretaría de Hacienda y Crédito Público la información que requieran para la evaluación y diseño de la política fiscal y aduanera, y para elaborar los informes que la Secretaría esté obligada a presentar;

Con base en lo anterior, podemos decir que el SAT, por tanto, ostenta un papel sumamente relevante en cuanto a su competencia en materia aduanera, ya sea por sus funciones materialmente legislativas, fiscales, aduaneras o de vigilancia, por lo que en el siguiente apartado se enlistan los ámbitos de competencia y de actuación legal de esta autoridad administrativa.

Como hemos podido observar, la Administración General de Aduanas concentra la totalidad de las facultades y atribuciones respecto al desarrollo de la actividad aduanera.

\section{B. Facultades en materia de vigilancia}

La Administración General de Aduanas, de acuerdo con el artículo 21 del Reglamento Interior del Servicio de Administración Tributaria, también tiene facultades de vigilancia de los agentes aduanales. 
Cada aduana, señala la disposición anterior, estará a cargo de un administrador, del que dependerán los subadministradores de las aduanas, jefes de sala, jefes de departamento, jefes de sección, verificadores, verificadores técnicos, notificadores, oficiales de comercio exterior, visitadores, el personal al servicio de la Unidad de Apoyo para la Inspección Fiscal y Aduanera que ésta determine y el personal que el servicio requiera.

Las facultades de la Administración General de Aduanas en materia de vigilancia son:

V. [La] comprobación del cumplimiento de los requisitos y obligaciones inherentes a la concesión, autorización, registro o patente otorgada por esta Administración General;

XVII. Instrumentar y, en su caso, autorizar proyectos de tecnología de control de inspección no intrusiva en el reconocimiento aduanero o en la verificación de mercancía en transporte, así como las acciones que de estos proyectos deriven, considerando los servicios de soporte y mantenimiento especializado que coadyuven en la operación aduanera de conformidad con los lineamientos emitidos por la Administración General de Planeación;

$\cdots$

XXI. Vigilar y verificar el cumplimiento de las obligaciones del agente aduanal, mandatario de agente aduanal y dictaminador aduanero, así como tramitar, resolver e imponer sanciones en términos de las leyes aplicables por los actos u omisiones cometidos por aquéllos;

XLIII. Ordenar en su caso, y practicar, actos de revisión, reconocimiento, verificación, visitas domiciliarias, auditorías, inspección y vigilancia, para cerciorarse del cumplimiento de las disposiciones jurídicas que regulan y gravan la entrada y salida del territorio nacional de mercancías y medios de transporte, el despacho aduanero y los hechos y actos que deriven de éste o de dicha entrada o salida, así como del cumplimiento de los requisitos y las obligaciones inherentes a las autorizaciones, concesiones, patentes e inscripciones en registros a que se refiere la Ley Adua- 
nera y dejar sin efectos las visitas domiciliarias previstas en este artículo;

XLIV. Ordenar y realizar la inspección y vigilancia permanente en el manejo, transporte o tenencia de las mercancías en los recintos fiscales o fiscalizados;

XLVIII. Practicar inspecciones, actos de vigilancia y verificaciones, para comprobar el cumplimiento de las obligaciones de los contribuyentes, responsables solidarios y demás obligados en materia de impuestos, incluyendo los que se causen por la entrada o salida del territorio nacional de mercancías y medios de transporte, derechos, aprovechamientos, estímulos fiscales, franquicias y accesorios de carácter federal, de la determinación de la base de los impuestos generales de importación o exportación, la verificación y determinación de la clasificación arancelaria de las mercancías de procedencia extranjera, así como comprobar, de conformidad con los acuerdos, convenios o tratados en materia fiscal o aduanera de los que México sea parte, el cumplimiento de obligaciones a cargo de contribuyentes, importadores, exportadores, productores, responsables solidarios y demás obligados en materia de impuestos, inclusive en materia de origen, de acuerdo a las actuaciones levantadas por las oficinas consulares en términos del artículo 63 del Código Fiscal de la Federación; verificar el cumplimiento de las regulaciones y restricciones no arancelarias en las mercancías de comercio exterior, inclusive las normas oficiales mexicanas; declarar que las mercancías, vehículos, embarcaciones o aeronaves pasan a propiedad del Fisco Federal; inspeccionar y vigilar los recintos fiscales y fiscalizados y, en este último caso, vigilar el cumplimiento de los requisitos y las obligaciones derivadas de la concesión o autorización otorgada para prestar los servicios de manejo, almacenaje y custodia de mercancías de comercio exterior; verificar el domicilio que los contribuyentes declaren en el pedimento, la transmisión electrónica o en el aviso consolidado que establece la Ley Aduanera;

XLIX. Verificar y supervisar los servicios autorizados que facilitan el reconocimiento aduanero empleando tecnología no intrusiva; 
L. Ordenar y practicar visitas domiciliarias a los contribuyentes, a fin de verificar el cumplimiento de las obligaciones fiscales en materia de registro de contribuyentes, para comprobar los datos que se encuentran en el Registro Federal de Contribuyentes y realizar las inscripciones y actualizaciones de los mismos por actos de autoridad, en las materias a que se refiere el presente artículo;

LI. Dar a conocer a los contribuyentes, responsables solidarios, productores, importadores, exportadores y demás obligados en materia aduanera, los hechos u omisiones imputables a éstos, conocidos con motivo del ejercicio de sus facultades de comprobación y hacer constar dichos hechos y omisiones en las actas $\mathrm{u}$ oficios que para tal efecto se levanten, en términos de la Ley Aduanera y demás disposiciones jurídicas aplicables. 
SEGUNDA PARTE

\author{
LA GARANTÍA DE LA PRESUNCIÓN DE NO \\ RESPONSABILIDAD EN LOS PROCEDIMIENTOS \\ ADMINISTRATIVOS SANCIONADORES \\ EN GONTRA DE LOS AGENTES ADUANALES
}




\section{CAPÍTULO PRIMERO \\ LA PRESUNGIÓN \\ DE NO RESPONSABILIDAD}

La presunción de inocencia, en general, tiene como finalidad preservar en el destinatario de la norma un estado de no reproche jurídico (no culpabilidad, no responsabilidad) frente a actos de los órganos de poder en ejercicio del ius puniendi hasta en tanto se mantenga incólume ese derecho y no sea desvirtuado a través de un procedimiento o proceso penal. ${ }^{73}$

Este derecho va más allá del debido proceso, garantizando otros derechos fundamentales como la dignidad humana, la libertad, la honra y el buen nombre, que podrían resultar vulnerados por actuaciones penales o disciplinarias irregulares.

La naturaleza fundamentalmente procesal de la presunción de inocencia se manifiesta en el hecho de que la carga de la prueba recaiga sobre la administración, y tiene como consecuencia que la no práctica de una prueba solicitada por el agente aduanal o alguna persona no pueda perjudicar a éste. ${ }^{74}$

No es factible en ningún caso presumir una conducta infractora o culpable por el mero hecho de las especiales circunstancias que rodean al sujeto pasivo.

$\mathrm{Al}$ respecto, la Primera Sala de la Suprema Corte de Justicia de la Nación ha señalado que:

73 Herrera Pérez, Alberto, El derecho a la presunción de inocencia, México, Porrúa, 2012.

74 Nieto García, Alejandro, Derecho administrativo sancionador, Madrid, Tecnos, 2008. 
El artículo 20, apartado B, fracción I, de la Constitución Política de los Estados Unidos Mexicanos alude al principio de presunción de inocencia, que se define como el derecho de toda persona acusada de la comisión de un delito, a ser considerada como inocente en tanto no se establezca legalmente su culpabilidad y que, por su naturaleza, es propio del derecho sancionador. En efecto, el citado principio reposa en la necesidad de garantizarle al imputado que no será condenado sin que existan pruebas suficientes que destruyan su estatus de inocente; su finalidad es brindarle seguridad jurídica de que, si no se demuestra su culpabilidad, no debe dictársele una sentencia condenatoria. La Suprema Corte de Justicia de la Nación, a través de la Primera Sala, ya se ha pronunciado en el sentido de que el principio de presunción de inocencia tiene por objeto evitar que se sancione penalmente al probable responsable antes de que se demuestre su culpabilidad en sentencia definitiva y ha establecido que el citado principio pertenece al ámbito del derecho penal, porque está vinculado con la "responsabilidad penal" del inculpado en la comisión del delito. La Sala ha hecho extensiva la aplicación del mencionado principio al derecho administrativo sancionador sólo en cierta medida, pues ha determinado que "su traslado al ámbito administrativo sancionador debe realizarse con las modulaciones que sean necesarias para hacer compatible este derecho con el contexto institucional al que se pretende aplicar", en tanto que existen importantes diferencias entre un proceso penal y un procedimiento administrativo sancionador. Ha sostenido, además, que el principio de presunción de inocencia es inherente al derecho penal, porque está encaminado a evitar que se sancione al probable responsable en su persona hasta en tanto se acredite plenamente su culpabilidad. Situación que también puede presentarse en el procedimiento administrativo sancionador, en cuanto a que también se pueden imponer sanciones. ${ }^{75}$

75 Tesis aislada 1a./J.23/2015 (10a.), Primera Sala, Gaceta del Semanario Fudicial de la Federación, Décima Época, libro 17, t. I, abril de 2015, p. 331. 
Este traslado protector al ámbito administrativo se confirma con lo que ha determinado el Poder Judicial de la Federación, que impone la carga probatoria correspondiente al órgano administrativo investigador para demostrar plenamente la responsabilidad administrativa, en su carácter de acusador.

Es importante lo que ha señalado la Corte Interamericana de Derechos Humanos (en adelante CorteIDH) respecto del principio de la presunción de inocencia, ya que ha destacado, en diferentes casos, que el artículo 8.2 de la Convención Americana sobre Derechos Humanos (en adelante CADH) exige que una persona no pueda ser condenada mientras no exista prueba plena de su responsabilidad penal. Si obra contra ella prueba incompleta o insuficiente no es procedente condenarla, sino absolverla. En este sentido, la CorteIDH ha afirmado que "en el principio de presunción de inocencia subyace el propósito de las garantías judiciales, al afirmar la idea de que una persona es inocente hasta que su culpabilidad sea demostrada". La Corte considera, además, que

...el derecho a la presunción de inocencia es un elemento esencial para la realización efectiva del derecho a la defensa y acompaña al acusado durante toda la tramitación del proceso hasta que una sentencia condenatoria que determine su culpabilidad quede firme. Este derecho implica que el acusado no debe demostrar que no ha cometido el delito que se le atribuye, ya que el onus probandi corresponde a quien acusa. ${ }^{76}$

Tanto los tribunales del Poder Judicial federal de México como la CorteIDH han señalado que la garantía de la presunción de inocencia es plenamente aplicable a los procedimientos administrativos sancionadores. Es por ello que, atendiendo a las especiales características de la materia administrativa y la aplicación, así dispuesta por la jurisprudencia, tanto nacional como

76 Caso Ricardo Canese vs. Paraguay, sentencia del 31 de agosto de 2004, Fondo, reparaciones y costas. 
internacional, del principio de la presunción de inocencia, es mejor denominar a esta garantía, en el ámbito administrativo, como presunción de no responsabilidad.

Por lo tanto, en este trabajo nos referiremos a la garantía de no responsabilidad y sólo haremos mención del concepto presunción de inocencia en citas textuales o referencias constitucionales o jurisprudenciales. 


\section{LA PERSPEGTIVA GONSTITUGIONAL DE LA PRESUNGIÓN DE NO RESPONSABILIDAD}

\section{ASPEGTOS GENERALES}

Es de vital importancia establecer que el origen de la garantía de la presunción de no responsabilidad deriva de la Declaración de los Derechos del Hombre y del Ciudadano de 1789. También está regulada en la $\mathrm{CADH}$ y en el Pacto Internacional de los Derechos Civiles y Políticos. Nuestra Constitución reconoce expresamente la garantía de la presunción de inocencia para la materia penal desde la reforma constitucional del 18 de junio de 2008.

En los citados instrumentos internacionales y en la Constitución, la garantía de la presunción de inocencia aparece reconocida no sólo como una garantía procesal, sino también como derecho humano propio de un sistema democrático. La finalidad de esta garantía es limitar el ejercicio legítimo de la fuerza del Estado mediante el debido proceso.

De acuerdo con el maestro Góngora y Pimentel, ${ }^{77}$ "los cambios derivados de los distintos sucesos políticos, sociales, económicos y jurídicos en México repercutieron considerablemente en la administración pública e instituciones del Estado".

77 Góngora Pimentel, Genaro David, El reconocimiento del derecho administrativo sancionador en la jurisprudencia constitucional mexicana, pp. 256 y 257, disponible en: wrew.juridicas.unam.mx. 
Asegura que la importante obra de algunos juristas del siglo pasado, aun cuando forma parte de la doctrina clásica del derecho administrativo mexicano, no incluyó el estudio de las distintas transformaciones de diversos conceptos y figuras relacionados con esta disciplina jurídica; cita, entre otras, la nueva interpretación y alcances del acto administrativo, la justicia administrativa y el derecho administrativo sancionador.

Constitucionalmente, la presunción de inocencia es una síntesis del conjunto de garantías de los que goza la persona. En un Estado constitucional de derecho debe aplicarse como primer criterio rector que atraviese horizontalmente el contenido y estructura del procedimiento administrativo en cualquier materia, con la finalidad de que pueda ejecutarse legítimamente un acto de autoridad que limite o restrinja los derechos de una persona.

En el contexto de esta visión constitucional, cabe hablar de un procedimiento administrativo de orden democrático que apele a la presunción de no responsabilidad como una metodología que, inspirada en esta garantía como momento inicial, introduzca textualmente en la legislación aduanera la aludida perspectiva constitucional, en la que los derechos fundamentales sustantivos del ciudadano ocupan el primer plano y adquieren una dimensión procedimental mediante reglas básicas que eviten una afectación a la esfera jurídica de cualquier persona, y concretamente en la del agente aduanal.

Dentro del derecho comparado basta con mencionar un dato significativo que refiere el Tribunal Constitucional español al sostener el criterio de que en los casos de sanciones administrativas suelen aplicarse principios de derecho penal.

La opinión autorizada de este Tribunal y los avances de la doctrina procesal mexicana incitan a reflexionar sobre la urgencia de incorporar la garantía de la presunción de no responsabilidad en el procedimiento administrativo en general, y en particular en los casos en los que inicie dicho procedimiento debido a la probabilidad de haberse presentado una causa de cancelación de la patente del agente aduanal, sobre todo cuando, sin mediar la 
garantía de la audiencia previa, se impone como medida cautelar la suspensión en el ejercicio de funciones.

A pesar de que, como en el caso de México, explica Góngora Pimentel, ${ }^{78}$ existe el desconocimiento casi generalizado de esta importante rama del derecho administrativo y, por tanto, su estudio y aplicación se encuentran en una etapa muy temprana, todavía observamos que algunas sanciones administrativas carecen de las garantías que aseguran la correcta tutela de los derechos o bienes jurídicos en cuestión.

Entre esta clase de sanciones localizamos, sin duda, la cancelación de la patente de agente aduanal en los asuntos que tienen que ver con las causales de cancelación de la patente, mediante un procedimiento en el que se aplica, sin la garantía de audiencia previa, la medida cautelar consistente en la suspensión de las funciones, afectando el derecho fundamental del debido proceso del agente aduanal, entre muchos otros derechos.

En efecto, la Primera Sala de la Suprema Corte de Justicia de la Nación señaló que:

...el criterio de que la garantía de audiencia previa consagrada en el artículo 14 de la Constitución Política de los Estados Unidos Mexicanos es de observancia obligatoria únicamente tratándose de actos privativos, entendiéndose por éstos, aquellos que constituyen un fin por sí mismos, con existencia independiente. En congruencia con tal criterio y tomando en consideración que existe jurisprudencia del Pleno de este alto tribunal en la que se estableció la constitucionalidad de la fracción X del artículo 147 de la Ley Aduanera abrogada, cuyo texto es idéntico al del numeral 164, fracción IV, de la ley vigente, resulta inconcuso que la suspensión en el ejercicio de las funciones de un agente aduanal prevista en el precepto últimamente citado, para el caso de que aquél se encuentre sujeto a un procedimiento de cancelación de la patente, no requiere el otorgamiento de la garantía constitucional de referencia. Lo anterior es así, porque la mencionada sus-

78 Ibidem, p. 258. 
pensión constituye una medida provisional accesoria y sumaria que pretende garantizar no sólo la eficacia de la cancelación, sino también el interés público y fiscal, y que no entraña propiamente un acto privativo de carácter definitivo, en virtud de que sólo durará hasta en tanto se dicte la resolución respectiva. Además, la referida medida tiene el carácter de cautelar, pues se adopta como reacción ante ciertos riesgos o perturbaciones aduaneras y supone, por su contenido y fin, cautelas para evitar lesiones al interés público protegido, o para impedir la continuación de sus efectos antijurídicos, dadas las infracciones consignadas en el acta de inicio del procedimiento administrativo en materia aduanera. ${ }^{79}$

La correcta función y delimitación de las facultades punitivas del Estado dependen del reconocimiento e identificación de los derechos y garantías constitucionales propios del derecho administrativo sancionador. Mientras no se consolide esta disciplina jurídica, la autoridad debe optar por aplicar la garantía de presunción de no responsabilidad como línea estructural del procedimiento administrativo, no sólo para todos los actos de molestia que afectan la función del agente aduanal, como en el caso de la suspensión como medida cautelar, sino también para cualquier acto administrativo que sea privativo de derechos.

De modo que en el derecho administrativo sancionador la incorporación de la garantía de la presunción de inocencia resulta indispensable; por tanto, está plenamente justificada la aplicación del artículo 20, apartado B, fracción I, de la Constitución Política de los Estados Unidos Mexicanos, que expresamente indica como uno de los derechos de toda persona imputada: "a que se presuma su inocencia mientras no se declare su responsabilidad mediante sentencia emitida por el juez de la causa".

79 Tesis aislada 1a.LXXVIII/2001, Primera Sala, "AGENTE ADUANAL. LA SUSPENSIÓN EN EL EJERGIGIO DE SUS FUNGIONES PREVISTA EN EL ARTÍCULO 164, FRACGIÓN IV, DE LA LEY ADUANERA NO REQUIERE EL OTORGAMIENTO DE LA GARANTÍA DE AUdiEncIA PREVIA", Semanario fudicial de la Federación, Novena Época, t. XIV, agosto de 2001, p. 165. 
Por esta razón, delimitar las facultades punitivas del Estado en materia administrativa, a partir de la Constitución, representa una tarea de primer orden, que impone la obligación de trasladar la garantía de la presunción de inocencia al procedimiento administrativo que se sigue contra un agente aduanal que presumiblemente realizó acciones u omisiones que constituyen alguna causa de cancelación de la patente.

En el marco de la Constitución, el poder de investigar lo ocurrido en un trámite realizado por el agente aduanal y de sancionar una infracción cuando sea el caso, con el resultado de esa investigación, no es en absoluto ilimitado, sino que se halla sometido a la Constitución. Si esa investigación se lleva a cabo vulnerando los derechos fundamentales del agente aduanal y en el ejercicio de la potestad punitiva del Estado, constituye, sin lugar a duda, una extralimitación.

\section{EL BLOQUE DE GONSTITUCIONALIDAD Y LA PRESUNGIÓN DE NO RESPONSABILIDAD}

Entendemos por bloque de constitucionalidad a la unidad jurídica compuesta por normas y principios que, sin aparecer textualmente en la Constitución, forman parte de la misma y deben tener aplicación directa y eficaz. ${ }^{80}$

Sin duda, la garantía de presunción de no responsabilidad forma parte de este bloque de constitucionalidad como principio rector en los procedimientos que involucran la actividad punitiva del Estado.

De acuerdo con lo explicado anteriormente y con fundamento en el artículo 8o. de la $\mathrm{CADH}$, podemos señalar que la presunción de no responsabilidad es una garantía del derecho humano al debido proceso. Se interrelaciona, además, con otras garantías también contenidas en la Constitución y en los artícu-

80 López Olvera, Miguel Alejandro y Pahuamba Rosas, Baltazar, Nuevos paradigmas constitucionales, México, ESPRESS, 2014, p. 81. 
los 8o. y 25 de la $\mathrm{CADH}$, así como con otros derechos, principios y prohibiciones que derivan de la propia Constitución y de la propia Convención.

Pero es importante precisar, para poder entender la función de esta importante figura jurídica, que se trata de una garantía que debe ser respetada e interpretada a la luz del nuevo paradigma de los derechos humanos.

Al respecto, el Tercer Tribunal Colegiado del Vigésimo Séptimo Gircuito señaló que:

Antes de las reformas constitucionales de 6 y 10 de junio de 2011, las voces "derechos humanos y sus garantías" eran términos que solían confundirse, ambigüedad que posiblemente derivaba de la anterior denominación del capítulo I de la Constitución Política de los Estados Unidos Mexicanos, titulado "De las garantías individuales". Sin embargo, el poder reformador de la Constitución, con las citadas reformas, elevó a rango constitucional su distinción, como deriva de las siguientes menciones: i) el capítulo I cambió su denominación a "De los derechos humanos y sus garantías"; ii) en el artículo 1o. se especificó que todas las personas gozarán de los derechos humanos reconocidos en la Constitución y en los tratados internacionales, "así como de las garantías para su protección”, y iii) en el numeral 103, fracción I, se especificó que los tribunales de la federación resolverán toda controversia que se suscite por infracción a los derechos humanos y las "garantías otorgadas para su protección”. Luego, para el constituyente permanente los derechos y sus garantías no son lo mismo, ya que éstas se otorgan para proteger los derechos humanos; constituyen, según Luigi Ferrajoli, los "deberes consistentes en obligaciones de prestación o en prohibiciones de lesión, según que los derechos garantizados sean derechos positivos o derechos negativos", es decir, son los requisitos, restricciones, exigencias u obligaciones previstas en la Constitución y en los tratados, destinadas e impuestas principalmente a las autoridades, que tienen por objeto proteger los derechos humanos; de ahí que exista una relación de subordinación entre ambos conceptos, pues las garantías sólo existen en función de los derechos que protegen; de tal suerte que 
pueden existir derechos sin garantías pero no garantías sin derechos. Así, a manera de ejemplo, puede decirse que el derecho humano a la propiedad tiene, entre otras garantías, las de audiencia y legalidad, pues prohíbe a la autoridad molestar a un particular sin mandamiento escrito en el que funde y motive la causa legal del procedimiento, y que los gobernados sean privados de la propiedad sin previa audiencia. ${ }^{81}$

Específicamente, en los procedimientos administrativos sancionadores también se debe respetar el derecho humano al debido proceso y sus diferentes garantías, entre las que se encuentra la de presunción de inocencia, en virtud de que también la CorteIDH ha señalado que "las autoridades públicas que adopten decisiones que determinen derechos, que formalmente no son juez o tribunal, no les son exigibles aquellas garantías propias de un órgano jurisdiccional, pero sí deben cumplir con las garantías destinadas a asegurar que la decisión no sea arbitraria". ${ }^{82}$

El Pleno de la Suprema Corte de Justicia de la Nación señaló que:

...de la interpretación armónica y sistemática de los artículos 14, párrafo segundo, 16, párrafo primero, 19, párrafo primero, 21, párrafo primero y 102, apartado A, párrafo segundo, de la Constitución Política de los Estados Unidos Mexicanos (en su texto anterior a la reforma publicada en el Diario Oficial de la Federación el 18 de junio de 2008), deriva implícitamente el principio de presunción de inocencia; el cual se contiene de modo expreso en los diversos artículos 8o., numeral 2, de la Convención Americana sobre Derechos Humanos y 14, numeral 2, del Pacto Interna-

81 Tesis de jurisprudencia XXVII.3o. J/14 (10a.), "DERECHOS HUMANOS Y SUS GARAnTÍAS. SU Distinción”, Tercer Tribunal Colegiado del Vigésimo Séptimo Circuito, Gaceta del Semanario Judicial de la Federación, Décima Época, libro 17, t. II, abril de 2015, p. 1451.

82 Ibáñez Rivas, Juana María, "Artículo 8. Garantías judiciales", en Steiner, Christian y Uribe, Patricia (coords.), Convención Americana sobre Derechos Humanos comentada, México, SCJN-Konrad Adenauer Stiftung, 2014, p. 215. 
cional de Derechos Civiles y Políticos; de ahí que, al ser acordes dichos preceptos - porque tienden a especificar y a hacer efectiva la presunción de inocencia-, deben interpretarse de modo sistemático, a fin de hacer valer para los gobernados la interpretación más favorable que permita una mejor impartición de justicia de conformidad con el numeral 1o. constitucional. ${ }^{83}$

Además de lo anterior, cabe destacar que los procedimientos administrativos sancionadores son mixtos, es decir, que son tramitados por diferentes órganos del Estado y en dos modalidades: tradicional y en línea.

Por lo cual, los órganos encargados de su tramitación deben vigilar que los derechos humanos, las garantías y los principios que rigen en estos procedimientos de cancelación, extinción y suspensión sean respetados tanto en línea como en el formato tradicional.

En la Resolución A/RES/68/198, denominada "Las tecnologías de la información y las comunicaciones para el desarrollo", la Asamblea General de la ONU destacó "la importancia del respeto de los derechos humanos y las libertades fundamentales en el uso de tecnologías de la información y las comunicaciones", y reafirmó "que los mismos derechos que tienen las personas fuera de línea también deben ser protegidos en línea". ${ }^{84}$

El artículo 8o. de la $\mathrm{CADH}$, denominado "garantías judiciales", enumera en su apartado $8.1^{85}$ los elementos que debe contener el derecho humano al debido proceso en materia admi-

83 Tesis de jurisprudencia P./J.43/2014 (10a.), Pleno, Gaceta del Semanario Fudicial de la Federación, Décima Época, libro 7, t. I, junio de 2014, p. 41.

84 Resolución A/RES/68/198, "Las tecnologías de la información y las comunicaciones para el desarrollo", aprobada por la Asamblea General de la ONU el 20 de diciembre de 2013, p. 3.

85 Textualmente, el artículo 8o. de la Convención Americana sobre Derechos Humanos dice: "Toda persona tiene derecho a ser oída, con las debidas garantías y dentro de un plazo razonable, por un juez o tribunal competente, independiente e imparcial, establecido con anterioridad por la ley, en la sustanciación de cualquier acusación penal formulada contra ella, o para la de- 
nistrativa, al ser éste igualmente aplicable a toda situación en la que alguna autoridad pública, no judicial, dicte resoluciones que diriman obligaciones y derechos.

\section{PRESUNCIÓN DE NO RESPONSABILIDAD \\ Y DERECHO ADMINISTRATIVO SANGIONADOR}

Como lo menciona Góngora Pimentel, el derecho administrativo sancionador estudia lo relativo a la potestad sancionadora de la administración, que implica la acción punitiva del Estado (ius puniendi). Debemos añadir que esta potestad está dirigida a sancionar acciones u omisiones que lesionen el adecuado desarrollo de la administración pública. Jaime Ossa aporta la siguiente definición sobre la potestad sancionadora, en la que explica que es "una atribución propia de la administración que se traduce en la posibilidad jurídica de la imposición de sanciones a los particulares y aún a los funcionarios que infringen sus disposiciones, o a sus servidores que, en el ejercicio de sus funciones, transgreden sus mandatos o desconocen sus prohibiciones". ${ }^{86}$

En este sentido, para la aplicación de sanciones el procedimiento administrativo tiene sus reglas y principios. Además, adopta algunos principios propios del derecho penal, y de entre los más trascendentes destacan el principio de presunción de inocencia y el debido proceso.

Indudablemente que la incorporación del principio de presunción de no responsabilidad en esta fase inicial del procedimiento administrativo, que comprende la aplicación de la medida cautelar citada, se erige como un medio de control efectivo tendente a la protección de los derechos fundamentales y de las

terminación de sus derechos y obligaciones de orden civil, laboral, fiscal o de cualquier otro carácter".

86 Ossa Arbeláez, Jaime, Derecho administrativo sancionador. Hacia una teoría general y una aproximación a su autonomía, Bogotá, Legis, 2000, p. 126. 
garantías del debido proceso, en la actividad del agente aduanal que regula la legislación en la materia.

Cotidianamente, en la práctica jurídica ocurre en diversos casos que sin el respeto a la garantía de audiencia previa el agente aduanal queda suspendido e impedido para llevar a cabo sus funciones en virtud de que al inicio del procedimiento administrativo, sin prueba determinante sobre la causa de suspensión, es impuesta la medida cautelar, limitando al agente aduanal en sus derechos y provocando graves consecuencias jurídicas y económicas a la posición de garante con la que actúa frente a las mercancías de un tercero y a su posición de sujeto de derechos.

De acuerdo con la Primera Sala de la Suprema Corte de Justicia de la Nación, los actos de privación se rigen por el artículo 14 de la Constitución federal y se caracterizan por ser definitivos; mientras que los de molestia se relacionan con el numeral 16 del pacto federal, y se distinguen de aquéllos por ser provisionales y carecer de definitividad. En ese orden, resulta inconcuso que el artículo 167 de la Ley Aduanera, al prever la suspensión en las funciones del agente aduanal durante el trámite de un procedimiento administrativo sancionador de cancelación de patente, y hasta en tanto se pronuncie la resolución definitiva, no viola el artículo 14 constitucional porque se refiere a un acto o medida de carácter provisional o transitorio, no definitivo, ya que sólo subsiste hasta en tanto se pronuncie la resolución definitiva en el procedimiento administrativo sancionador, de manera que en estos casos es inaplicable la garantía de previa audiencia. ${ }^{87}$

87 Tesis aislada la.LXV/2004, Primera Sala, "AGENTES ADUANALES. LoS ARTÍCULOS 164, FRACGIÓN IV Y 165, FRACCIÓN III, DE LA LEY ADUANERA VIGENTE EN DOS MIL DOS, QUE PREVÉN LA SUSPENSIÓN EN SUS FUNCIONES, HASTA EN TANTO SE PRONUNCIE LA RESOLUCIÓN DEFINITIVA EN EL PROCEDIMIENTO DE CANCELACIÓN DE LA PATENTE RESPECTIVA, NO VIOLA LA GARANTÍA DE AUDIENGIA PREVISTA EN EL ARTÍCULO 14 DE LA CONSTITUCióN FEDERAL", Semanario Fudicial de la Federación, Novena Época, t. XIX, junio de 2004 , p. 232. 
En su interesante estudio, Góngora Pimentel concluye que "los controles establecidos para el derecho administrativo sancionador se basan esencialmente en los principios que integran el orden jurídico y establecen un equilibrio en la aplicación de las sanciones que afectan las vidas y el patrimonio de las personas".

Desde luego, cualquier disciplina jurídica tiene su punto de partida en la aplicación de principios, y en razón de ello es indudable que el principal límite y equilibrio para la suspensión del agente aduanal en el ejercicio de sus funciones justamente debiera radicar en la observancia de la garantía de presunción de no responsabilidad.

Nada cabría objetar, desde la perspectiva de los derechos de la persona, a que algo que no podemos saber con certeza limite la reacción punitiva del Estado. Esto no ocurre así cuando la autoridad aduanera lleva a cabo, sin mayor prueba que la información unilateral recolectada, la suspensión en el ejercicio de sus funciones al agente aduanal en la apertura o inicio de un procedimiento administrativo sancionador tendente a investigar la presencia de alguna causa que justifique la cancelación de la patente. En este supuesto jurídico, la reacción punitiva del Estado, sin que haya una verdadera necesidad, limita un derecho, violando la presunción de no responsabilidad.

El Séptimo Tribunal Colegiado en Materia Administrativa del Primer Circuito señaló, al respecto, que:

En el supuesto de que las autoridades aduaneras conozcan hechos u omisiones que ameriten la imposición de esa sanción, deben proceder de la forma siguiente: a) Dar a conocer en forma pormenorizada al agente aduanal los hechos u omisiones que se le imputan, que podrían ocasionar la aplicación de la sanción en cita; y, b) Conceder a esa persona un plazo de diez días hábiles para que ofrezca pruebas y exprese lo que a su derecho convenga. Lo anterior se deduce del texto del párrafo tercero del artículo 167 de la Ley Aduanera, de tal suerte que para dar inicio al procedimiento de cancelación de la patente de un agente aduanal no se requiere que la autoridad acredite la certeza de las manifesta- 
ciones de la persona que presenta la denuncia respectiva o alguna otra circunstancia. ${ }^{88}$

Por lo tanto, en el procedimiento administrativo sancionador la presunción de no responsabilidad debe atravesar cualquier normativa que afecte o limite derechos fundamentales, debido a que en esta clase de asuntos el núcleo esencial del derecho constitucional está enclavado en la garantía de presunción de no responsabilidad, que puede enunciarse diciendo que toda persona ha de ser tratada y sometida a un procedimiento en tanto su responsabilidad no resulte probada más allá de toda duda razonable, con base en pruebas que puedan considerarse suficientes y que éstas hayan sido obtenidas con todas las garantías que la ley otorga a la persona frente al aparato estatal.

La doctrina respalda ampliamente esta posición. Un ejemplo de esto lo encontramos en el pronunciamiento de Jaime Ossa Arbeláez, citado por Góngora Pimentel, en los siguientes términos:

De acuerdo con el fundamento de la primacía de las garantías del administrado, la enumeración de los principios del derecho administrativo sancionador no puede ser limitativa; por ende, en términos generales se reconoce la legalidad, tipicidad, presunción de inocencia, debido proceso, proporcionalidad, nulla poena sine lege, caso fortuito, favorabilidad, culpabilidad, imparcialidad, no reformatio in pejus, no retroactividad de la ley, non bis in idem, prohibición de la analogía, reserva de ley, in dubio pro-reo, igualdad ante la ley, publicidad, contradicción y control jurisdiccional. ${ }^{89}$

Consiguientemente, la presunción de inocencia debe ser trasladada al procedimiento administrativo sancionador cuando

88 Tesis aislada I.7o.A.177A, Séptimo Tribunal Colegiado en Materia Administrativa del Primer Circuito, "Agente AduAnal. Procedimiento ADMINISTRATIVO DE CANCELACIÓN DE SU PATENTE. NO ES NEGESARIO QUE LA AUTORIDAD VERIFIQUE LA GERTEZA DE LAS AFIRMACIONES DEL DENUNCIANTE", Semanario Fudicial de la Federación, Novena Época, t. XVI, julio de 2002, p. 1238.

89 Góngora Pimentel, Genaro David, op. cit., p. 262. 
se trata de la cancelación de la patente a un agente aduanal, como presunción de no responsabilidad, con la finalidad de eliminar cualquier riesgo de afectación a un derecho fundamental que puede presentarse cuando, sin mayor indagación, la autoridad aduanera ordena en el inicio del procedimiento la medida cautelar de suspensión en el ejercicio de funciones del agente aduanal, sin respetar la garantía de la audiencia previa, el derecho a la defensa y el principio de contradicción.

De manera ordinaria, en estos casos hay datos indiciarios de que el agente aduanal en el ejercicio de sus funciones probablemente colocó su conducta en alguna de las causas que ameritan la cancelación de la patente. Por tanto, ante esa hipótesis, la apertura del procedimiento administrativo debe tener como exigencia primordial el evitar la violación al debido proceso, de modo que se hace evidente la necesidad de introducir el derecho del agente aduanal a que se presuma su inocencia hasta que más allá de toda duda razonable pueda declararse su responsabilidad mediante la resolución que pone fin al procedimiento.

$\mathrm{Su}$ importancia radica en establecer límites que impidan el abuso de facultades de la autoridad, en detrimento de los derechos del agente aduanal, cuando es ordenada la suspensión como medida cautelar en el procedimiento de cancelación en el ejercicio de sus funciones. Como medida cautelar concreta representa una grave restricción al derecho de libertad de trabajo del individuo, debido a que al inicio del procedimiento administrativo aún no hay certeza de que la actividad desplegada sea constitutiva de alguna de las causas de suspensión previstas en la Ley Aduanera.

Ante la falta de definición normativa en este acto privativo en la función del agente aduanal y su aplicación inmediata, es necesario acudir a la aplicación analógica de la garantía de presunción de no responsabilidad. 


\section{CAPÍTULO TERCERO \\ LA FUNCIÓN DE GARANTÍA \\ DE LA PRESUNGIÓN DE NO RESPONSABILIDAD}

\section{ASPECTOS GENERALES}

Nuestro país pertenece a la comunidad internacional que, como Estado parte, salvaguarda la garantía de presunción de no responsabilidad contemplada en la Declaración Americana de los Derechos y Deberes del Hombre, la Declaración Universal de Derechos Humanos, el Pacto Internacional de Derechos Civiles y Políticos, y la CADH.

Por ese motivo, resulta ineludible la obligación de incorporar esta garantía a la Ley Aduanera en relación con las decisiones que imponen la suspensión en el ejercicio de funciones del agente aduanal. En el derecho positivo mexicano, la presunción de inocencia aparece textualmente reconocida en la Constitución; sin embargo, no ha tenido los resultados esperados en la práctica jurídica respecto a su total y efectiva aplicación.

Una aspiración legítima de los ciudadanos en nuestro país es, en buena medida, la introducción de un sistema de garantías mediante el cual las personas puedan oponer sus razones, en términos de igualdad, a las pretensiones del aparato estatal cuando ordena la restricción o limitación de derechos en determinados actos administrativos.

En definitiva, el objetivo de evitar que sean lesionados los derechos del agente aduanal por el aparato estatal se logra si en el sistema jurídico mexicano las decisiones de la autoridad ad- 
ministrativa se ciñen a la reforma constitucional del 11 de junio de 2011.90 De ello surge la posibilidad de cuestionar sobre si es suficiente con la interpretación de los artículos 1o. y 14 constitucionales para que el procedimiento administrativo sancionador en México se estructure bajo la garantía de la presunción de no responsabilidad o si, simplemente, debe aplicarse sin cortapisas.

Aquí conviene destacar que el artículo 1o., vinculado con el artículo 20, apartado B, fracción I, ambos constitucionales, son normas que ética y jurídicamente imponen a la autoridad aduanera la obligación de respeto a la garantía de presunción de inocencia de la persona frente al reclamo estatal en cualquier procedimiento administrativo que sea iniciado para determinar la cuestión de transgresión o no a las normas sustantivas y procesales aplicables en las actividades del agente aduanal.

La presunción de no responsabilidad requiere de un sistema de garantías mediante el cual el agente aduanal pueda oponer sus razones, en términos de igualdad, a las del aparato estatal. Las nuevas relaciones de poder habrán de ajustarse al cambio de paradigma que marca el artículo 1o. constitucional. Esas relaciones que vinculan la actividad de los agentes aduanales y las decisiones del aparato estatal exigen una nueva configuración que incorpore el debido proceso y la garantía de presunción de no responsabilidad, ${ }^{91}$ dando preeminencia desde el inicio del procedimiento administrativo al principio de contradicción, con el objeto de que el agente aduanal pueda tener una defensa adecuada y oportuna frente al acto administrativo que lo suspende provisionalmente en el ejercicio de sus funciones dentro de una investigación para la cancelación de la patente.

90 Véase Vázquez, Luis Daniel y Serrano, Sandra, "Los principios de universalidad, interdependencia, indivisibilidad y progresividad. Apuntes para su aplicación", en Carbonell, Miguel y Salazar, Pedro (coords.), La reforma constitucional de derechos humanos: un nuevo paradigma, México, UNAM, 2011, pp. 137 y 138.

91 La CorteIDH, en el Caso Baena Ricardo vs. Panamá, párrafo 124, así lo reconoce expresamente. 
Con el reconocimiento a la presunción de no responsabilidad en la práctica jurídica del procedimiento administrativo sancionador se evidencia que la reforma en materia de derechos humanos es el producto de una transición democrática. El objetivo principal radica en que la autoridad aduanera debe afrontar el reto de mantener el equilibrio entre el respeto a los principios de economía, eficacia y eficiencia, y el sistema de garantías en el procedimiento administrativo, que busca sancionar la conducta del agente aduanal, pero sin quebrantar sus derechos fundamentales.

El gran reto radica en descender la reforma constitucional a la legislación aduanera, regulando de manera expresa la presunción de no responsabilidad como una garantía fundamental en el procedimiento administrativo sancionador, con el carácter de garantía del derecho humano al debido proceso, de manera que sea un mecanismo útil que dé respuesta, en igualdad de circunstancias, a la facultad sancionadora del aparato estatal.

Incluso porque el mejor argumento que protege los derechos fundamentales de un agente aduanal, frente a la autoridad aduanera, deriva de la aplicación del debido proceso y de la garantía de la presunción de no responsabilidad que tiene, por tanto, el doble significado que le ha otorgado el maestro Vives Antón:92 como regla de tratamiento y como regla de juicio.

Como regla de tratamiento, que comprende un determinado modo de tratar la conducta infractora del agente aduanal, cuando se aplica la medida cautelar en la apertura del procedimiento. En esta decisión temprana puede aplicarse directamente la garantía de la presunción de no responsabilidad, estrictamente razonado, para evitar considerarle "responsable" de antemano del incumplimiento de las obligaciones previstas en los artículos 54 y 162 de la Ley Aduanera, sin pruebas de cargo suficientes que pongan fuera de duda la existencia de esa responsabilidad,

92 Vives Antón, Tomás S., Fundamentos del sistema penal. Acción significativa y derechos constitucionales, 2a. ed., Valencia, Tirant lo Blanch, 2011, pp. 884 y 886. 
quizá por quebrantar alguno de los enunciados normativos de la mencionada disposición.

Otra perspectiva de la presunción de no responsabilidad es aplicarla como regla de juicio; en este sentido, la autoridad administrativa tiene el deber jurídico de verificar que, con pruebas suficientes, la culpabilidad del agente aduanal sea probada más allá de toda duda razonable para que pueda producirse la resolución que provisionalmente suspende al agente aduanal en sus funciones.

Por ello, resulta indispensable, no sólo desde la perspectiva de la verdad sino del desarrollo adecuado de la justicia administrativa, que la incriminación de la autoridad aduanera y la defensa del agente aduanal puedan contribuir a la determinación del hecho en condiciones de igualdad.

Ante la imposibilidad de derivación legislativa que pueda invocar la autoridad aduanera cuando se le pide que haga efectiva la garantía de presunción de no responsabilidad en el procedimiento administrativo sancionador - por no encontrarse expresamente regulado en la ley de la materia - se tiene la alternativa de aplicación del artículo 1o. constitucional, en lo referente a la interpretación conforme y el principio pro persona, que hacen posible la función de garantía del principio de presunción de no responsabilidad. ${ }^{93}$ Ya que los citados principios inciden en las posibilidades procesales de hacer valer los derechos ante la autoridad aduanera que, con la apertura del procedimiento, pretende llevar a cabo la cancelación de la patente y aplicar inmediatamente la suspensión del agente aduanal en el ejercicio de sus funciones, en los casos previstos por el artículo 167 de la citada ley.

Lo relevante ahora es destacar que la posición procesal de los agentes aduanales es equivalente a la de cualquier ciudadano, por tanto, son titulares, también, del derecho de acceso al procedimiento administrativo, con las garantías del debido proceso y

93 Véase López Olvera, Miguel Alejandro, El control de convencionalidad en la administración pública, México, Novum, 2014, p. 181. 
la articulación de la garantía de presunción de no responsabilidad. Aunque el artículo 20, apartado B, fracción I, constitucional no exige de la ley secundaria la articulación, ésta aparece dada en el contexto del artículo 1o. constitucional al aplicar la interpretación conforme y el principio pro persona. ${ }^{94}$

El alcance limitado de la redacción hacia el imputado del artículo 20, apartado B, fracción I, constitucional, que consagra la garantía de la presunción de no responsabilidad, actúa — según venimos diciendo - respecto a la interpretación conforme y al principio pro persona, no en relación con un sujeto denominado "imputado" sino, en general, para cualquier persona sometida al ius puniendi estatal, en este caso del agente aduanal contra quien se apertura un procedimiento administrativo sancionador tendente a la cancelación de la patente.

Así que la interpretación teleológica de las normas de acceso a la justicia en el procedimiento administrativo - como un recurso de tutela efectiva para el agente aduanal - estarán guiadas también por el canon constitucional de eliminación de la arbitrariedad, la irrazonabilidad y el error latente que suele afectar con la medida cautelar de suspensión, desde la apertura del procedimiento administrativo, el derecho del agente aduanal al ejercicio libre y responsable de su derecho a llevar a cabo las actividades derivadas de la patente otorgada, en los términos que indica el artículo 159 de la Ley Aduanera.

\section{EN LOS PROCEDIMIENTOS EN MATERIA ADUANERA}

Aun cuando en la práctica administrativa la autoridad aduanera tiene el imperativo de preservar la presunción de inocencia reglada constitucionalmente, semejante imperativo no se refleja en la apertura del procedimiento al ordenar como medida cautelar la suspensión del agente aduanal en el ejercicio de sus funciones. En

94 Ibidem, p. 182. 
consecuencia, tampoco lo analizan las resoluciones de la autoridad aduanera debido, principalmente, al tradicional argumento retórico del "interés público" que introducen concretamente al ordenar la citada medida cautelar, lo que impide materialmente la aplicación de la garantía de presunción de no responsabilidad.

Este problema denota la necesidad de reformar el sistema de medidas cautelares que en materia aduanera desdeñan la aplicación de la garantía de la presunción de no responsabilidad desde la etapa de inicio del procedimiento, ya que es incuestionable que la autoridad está prejuzgando el hecho atribuido al agente aduanal que actúa en cumplimiento de las obligaciones que le impone la Ley Aduanera.

Obsérvese que el artículo 167, párrafo 3, de la Ley Aduanera regula la suspensión provisional en el ejercicio de funciones del agente aduanal desde el inicio del procedimiento administrativo para la cancelación de la patente. ${ }^{95}$

Aunque la autoridad aduanera tiene el imperativo de preservar la garantía de la presunción de no responsabilidad y el derecho al debido proceso, la normativa ya mencionada resulta

95 La Primera Sala, al respecto, señaló que "los artículos 164, fracción IV y 165, fracción III, de la Ley Aduanera, al prever que cuando se incoe un procedimiento administrativo sancionador especial en materia aduanera en contra de un agente aduanal, pretendiéndose la cancelación de su patente por imputársele la infracción consistente en señalar en un pedimento aduanero el nombre, domicilio fiscal o la clave del registro federal de contribuyentes de alguna persona que no hubiere solicitado un trámite aduanero, o cuando los datos resulten falsos o inexistentes, aquél podrá ser suspendido en sus funciones durante la investigación, establecen una medida que se identifica, a nivel constitucional, con los actos de molestia, los cuales, para estimarse apegados al artículo 16 de la Constitución federal sólo requieren constar por escrito, ser emitidos por autoridad competente y estar debidamente fundados y motivados". Véase tesis aislada 1a.LXVI/2004, Primera Sala, "AGENTES ADUANALES. EL HECHO DE QUE LOS ARTÍCULOS 164, FRACCIÓN IV Y 165, FRACCIÓN III, DE LA LEY ADUANERA VIGENTE EN 2002, QUE PREVÉN COMO MEDIDA PROVISIONAL LA SUSPENSIÓN EN SUS FUNCIONES, NO REGULEN EN FORMA Y TÉRMINOS EL TRÁMITE DEL DESPACHO ADUANERO, NO VIOLAN LA GARANTÍA DE SEGURIDAD JURÍDICA PREVISTA EN EL ARTÍCULO 16 DE LA CONSTITUCIÓN FEDERAL", Semanario fudicial de la Federación, Novena Época, t. XIX, junio de 2004, p. 231. 
verdaderamente un obstáculo que fortalece la cultura inquisitiva en el procedimiento administrativo, constituida para mantener $a$ priori la responsabilidad del agente aduanal a partir de su apertura. El argumento siempre estará vinculado a una forma de hacer justicia administrativa en aras del interés jurídico y del orden público. Un ejemplo de ello se encuentra inmerso en el contenido de la tesis 1a.CLXIII/2005 de la Primera Sala de la Suprema Corte de Justicia de la Nación, que señaló:

...las prohibiciones previstas en el artículo 22 de la Constitución Política de los Estados Unidos Mexicanos no pueden predicarse de cualquier consecuencia jurídica, sino solamente de las penas en sentido estricto; de manera que si la cancelación de patente contenida en el artículo 165, fracción III, de la Ley Aduanera no es una pena (sanción penal), resulta ilógico considerar que la misma pueda calificarse a la luz del citado precepto constitucional, dirigido a la prohibición de sanciones penales inusitadas y trascendentales. ${ }^{96}$

Por ende, es particularmente importante deconstruir la estructura normativa que impone a la autoridad aduanera el deber ineludible de quebrantar la garantía de la presunción de no responsabilidad en la apertura del procedimiento administrativo sancionador, con la finalidad de que puedan decidir imparcialmente entre las pretensiones de verdad y validez del Estado, frente a las de los agentes aduanales afectados por algún acto de autoridad.

La Administración General de Aduanas es la autoridad idónea ${ }^{97}$ para impedir que un acto de autoridad de orden adminis-

96 Véase la tesis aislada 1a.CLXIII/2005, Primera Sala, "AGENTE ADUANAL. LA CANCELACIÓN DE SU PATENTE NO CONSTITUYE UNA PENA EN SENTIDO ESTRICTO, POR LO QUE NO PUEDE CALIFICARSE A LA LUZ DEL ARTÍCULO 22 De la Constitución federaL", Semanario fudicial de la Federación, Novena Época, t. XXIII, enero de 2006, p. 711.

97 El artículo 19 del Reglamento Interior del Servicio de Administración Tributaria señala las facultades de este órgano, dentro de las cuales se encuentra 
trativo quebrante los derechos del agente aduanal, con la finalidad de que la dignidad de la persona y el conjunto de derechos fundamentales que están vinculados a ella no queden expuestos al poder del Estado. Por ello, el procedimiento administrativo sancionador debe encontrarse atravesado por la presunción de inocencia, ${ }^{98}$ de esta manera queda garantizado el debido proceso para el agente aduanal que es sometido a un procedimiento de orden administrativo sancionador.

Las posiciones diversas entre las que la misma autoridad aduanera ha de optar, valorando imparcialmente los discursos justificativos entre su decisión unilateral, que representa al aparato estatal, y la posición de indefensión en la que está colocado el agente aduanal en el inicio del procedimiento administrativo - cuando se ordena la suspensión provisional como medida cautelar - demanda la urgente acogida de la presunción de inocencia como piedra angular de un sistema de garantías, que permitirá que la decisión final quede dada en un marco de respeto al debido proceso, sin lesionar los derechos del agente aduanal.

De otra forma, la suspensión provisional, como medida cautelar, en el ejercicio de funciones del agente aduanal afectará durante todo el procedimiento administrativo sancionador el derecho humano a que se reconozca la garantía de la presunción de no responsabilidad en cualquier hipótesis de investigación para la cancelación de la patente del agente aduanal.

Las hipótesis fácticas que llegan a presentarse en la práctica forense con cierta regularidad, tratándose de la suspensión en el ejercicio de funciones, hacen imprescindible la necesidad de que

la de llevar a cabo los procedimientos administrativos de vigilancia y sancionadores en materia aduanera.

98 Luis Cueva Carrión afirma que el debido proceso, y sus garantías, "debe ser observado y practicado en los procesos judiciales, legislativos y administrativos para que una sentencia, una ley o una resolución tengan validez jurídica". Véase Cueva Carrión, Luis, El debido proceso, 3a. ed., Quito, Ecuador, Ediciones Cueva Carrión, 2007, p. 62. 
la autoridad cumpla con el principio de contradicción y el respeto de la garantía de la presunción de no responsabilidad.

En otras palabras, que su posible infracción administrativa, en caso de existir, no puede dar lugar a una suspensión de funciones anticipada e inmediata porque esto comportaría la violación a la garantía de la presunción de no responsabilidad y una inaceptable discriminación respecto a otros procedimientos. Un esquema de garantía para la protección de los derechos que conforme al artículo 163 de la Ley Aduanera posee el agente aduanal se basa en el derecho fundamental a la tutela judicial efectiva frente al Estado, que debe probar sin cortapisas la causa generadora de una sanción "anticipada", como es el caso de la suspensión de sus funciones. ${ }^{99}$

El hecho que puede servir de base a una sanción de esta naturaleza, por presentarse alguna de las causas previstas en el artículo 164 de la Ley Aduanera, no es el acontecimiento histórico tal y como ha ocurrido, sino una reconstrucción ulterior. No hay nada que nos permita afirmar que una determinada versión del suceso es, sin más, verdadera. Hemos de contentarnos, pues, con aquella que resulte mejor justificada mediante el procedimiento probatorio, que debería iniciar desde la apertura del procedimiento administrativo cuando la legislación ordena la imposición de una medida cautelar que afecta o restringe el derecho al trabajo, entre muchos otros.

Desde esta perspectiva, las exigencias de un procedimiento administrativo apropiado forman parte de las razones que justifican la instalación del principio de contradicción y de la garantía de la presunción de no responsabilidad, que en una determinada versión de los hechos tenga como objetivo obtener una verdad consensuada en reglas. Dicho de otra manera, el modo de obtención de la verdad forma parte de las razones que evidencian que

99 Véase El acceso a la justicia como garantía de los derechos económicos, sociales y culturales. Estudios de los estándares fijados por el sistema interamericano de derechos humanos, Washington, D. C., Estados Unidos, Comisión Interamericana de Derechos Humanos, 2007. Disponible en: http://wrere.cidh.org. 
una determinada versión de los hechos sea tenida por verdadera, y el modo de obtención se integra por las razones que nos llevan a tenerla por verdad.

En efecto, debido a que en el procedimiento administrativo sancionador, como en cualquier otro, se reconstruye el acaecimiento histórico y no contamos, para efectuar esa reconstrucción en el inicio o apertura de este procedimiento, con una instancia absolutamente objetiva y desinteresada, la reconstrucción ha de llevarse a cabo necesariamente bajo la línea estructural de la garantía de presunción de no responsabilidad, dando oportunidad al agente aduanal de oponerse a la decisión de suspensión provisional mediante el principio del contradictorio, sin que el Estado que acusa pueda esgrimir el interés jurídico y el interés público en detrimento de los derechos fundamentales de aquél.

Debido a que si se vulneran los derechos fundamentales se quebranta el principio de igualdad procesal entre las partes, en consecuencia, la determinación de la verdad queda en definitiva en manos del Estado. Y la reconstrucción del suceso histórico efectuada unilateralmente por los representantes del poder estatal no reuniría las condiciones necesarias y suficientes para poder ser tenida como legítima a la hora de argumentar la imposición de la medida cautelar que contempla el artículo 167 de la Ley Aduanera.

Corresponde a la ley procesal determinar, entonces, los casos en los que los agentes aduanales disponen de acciones procesales para la defensa de sus derechos. Lógicamente, esta tarea de configuración legal, si no la encontramos expresamente en la ley respectiva, habrá de ejercerse con sometimiento al ordenamiento constitucional para impedir no sólo exclusiones procesales arbitrarias, sino incluso aquellas otras que, por su relevancia y extensión, pudieran hacer imposible el propio derecho de acceso a la justicia y a la tutela efectiva como derecho humano. 


\section{LA PRESUNGIÓN DE NO RESPONSABILIDAD COMO GARANTÍA ESTRUGTURAL Y SU INCORPORACIÓN AL PROCEDIMIENTO ADMINISTRATIVO SANGIONADOR MEXICANO}

\section{ASPEGTOS GENERALES}

La importancia de delimitar las facultades punitivas del Estado en materia administrativa, a partir de la Constitución, radica en la interpretación de los principios protectores de la materia penal, entre ellos la de presunción de no responsabilidad, que en su incorporación al procedimiento administrativo sancionador mexicano debe considerarse en su doble significado: como regla de tratamiento y como regla de juicio. ${ }^{100}$

Aunque en la reforma constitucional del 18 de junio de 2008 expresamente se consagró como derecho humano de acuerdo a los nuevos paradigmas del derecho internacional de los derechos humanos, en el procedimiento administrativo carece de esa tutela judicial efectiva que requiere para su adecuada aplicación, concretamente en la instrumentalización del procedimiento dirigido a la cancelación de la patente del agente aduanal, y en el que la resolución inicial que ordena la suspensión en el ejercicio de sus funciones afecta su esfera de derechos.

100 Véase López Olvera, Miguel Alejandro, El control de convencionalidad en la administración pública, cit., p. 142. 
Con esta finalidad, deben implementarse mecanismos para dotar de mayores garantías a los agentes aduanales frente al ejercicio del poder punitivo de la administración estatal, básicamente en aquellos casos en los que aparezca afectado en sus derechos fundamentales por una medida cautelar impuesta al inicio del procedimiento administrativo sancionador, debido a que generalmente se convierte en una pena anticipada, que igualmente afecta derechos de terceros a quienes representa.

Tiene sentido entonces destacar aquí que la prohibición de indefensión procedimental al agente aduanal protege inmediatamente a éste, pero también protege otros intereses que representa con su actividad y de esta forma garantiza el interés objetivo que se tiene, a fin de que el procedimiento administrativo constituya un instrumento idóneo en el eficaz desarrollo de la función administrativa. El artículo 159 de la Ley Aduanera deja claro este argumento: el agente aduanal actúa mediante una patente que le ha sido otorgada con la finalidad de que promueva por cuenta ajena el despacho de las mercancías en los diferentes regímenes aduaneros previstos por la citada ley.

Con ese funcionamiento adecuado en la protección de intereses se garantiza que el procedimiento administrativo, en el que actúan los agentes aduanales como representantes o apoderados de intereses particulares frente a la autoridad aduanera, esté desprovisto de toda indefensión. Así queda reforzada la confianza ciudadana en la estabilidad de las resoluciones que inician o ponen fin al citado procedimiento administrativo.

En definitiva, esto quiere decir que el derecho a no sufrir indefensión es el disfrute, por los agentes aduanales sometidos a un procedimiento administrativo sancionador, de las singulares garantías procesales que se enuncian en el debido proceso y cuya esencial vinculación la aporta la garantía de presunción de no responsabilidad, como línea estructural de dicho procedimiento. 
La presunción de no responsabilidad es, ante todo, una regla de juicio que descansa sobre la idea de que la culpabilidad sólo puede ser afirmada sobre la base de pruebas de las que ésta se infiera más allá de toda duda razonable. En la prueba trasladada al procedimiento administrativo sancionador para la suspensión del agente aduanal en sus funciones no debe confundirse la garantía de presunción de no responsabilidad con la certeza puramente subjetiva y, menos aún, con la sensación de certeza que en ocasiones emerge en la decisión preliminar y sin prueba de la autoridad aduanera que determine la necesidad de cautela.

Debemos partir de la idea democrática en el sentido de que los agentes aduanales son titulares, también, del derecho de acceso a la justicia mediante el debido proceso, amparados, como cualquier persona, por el derecho a no sufrir indefensión ${ }^{101}$ en la aplicación de la medida cautelar de suspensión en el ejercicio de sus funciones que prevé el artículo 167 de la Ley Aduanera.

Semejante reconocimiento de la garantía de presunción de no responsabilidad como derecho humano que fortalece el acceso a la justicia deberá incorporarse a todas las fases del procedimiento. $\mathrm{Y}$ asumirse sin cortapisas como una regla de juicio rigurosa que se inspira en una determinada concepción del hombre y su dignidad, que en forma inevitable conduce a instalar la presunción de inocencia como principio estructural del procedimiento administrativo sancionador, con el fin de evitar la afectación de los derechos que posee el agente aduanal autorizado por el Servicio de Administración Tributaria, mediante una patente, para promover por cuenta ajena el despacho de las mercancías en los diferentes regímenes aduaneros.

${ }^{101}$ Por ejemplo, la Carta Iberoamericana de los Derechos y Deberes del Ciudadano en relación con la administración pública, en su numeral 27, señala: "Derecho a la tutela administrativa efectiva: durante la sustanciación del procedimiento administrativo la administración estará sometida plenamente a la ley y al derecho y procurará evitar que el ciudadano interesado pueda encontrarse en situación de indefensión". 


\section{Aspectos TÉCNICOS}

Sobre la aplicación de la garantía de presunción de inocencia aparece la opinión autorizada de Aguilar López ${ }^{102}$ en el siguiente sentido:

...debe ser aplicado en todos los procedimientos de cuyo resultado pudiera derivar alguna pena o sanción como consecuencia de la facultad punitiva del Estado. Por ende, se constituye en el derecho humano de toda persona; incluso aplicable al procedimiento administrativo sancionador, modulándolo y matizándolo, según el caso, ya que la calidad de inocente de la persona debe reconocérsele a fin de desplazar la carga de la prueba a la autoridad acusadora en atención al derecho al debido proceso.

El procedimiento administrativo sancionador en estos casos tendrá que concebirse como un efectivo sistema de garantías frente a la facultad coercitiva del Estado. Su función no puede reducirse exclusivamente a ser un instrumento de imposición de sanciones anticipadas; por el contrario, debería elevarse como un instrumento de garantía de los derechos y libertades desde la apertura oficiosa del procedimiento.

No olvidemos que la naturaleza de las sanciones administrativas, en el plano de la política legislativa, queda bajo el contorno del concepto de pena en sentido amplio; por lo tanto, éste abarca tanto a las sanciones penales como a las sanciones administrativas - incluyendo las medidas cautelares - , con las garantías que le son propias y que en el procedimiento administrativo para la cancelación de una patente deben aplicarse: principio de legalidad, tipicidad, irretroactividad y culpabilidad, donde la presunción de inocencia como principio estructural se instituya como el estandarte más genuino que tiene un sistema procesal,

102 Aguilar López, Miguel Ángel, Presunción de inocencia. Derecho humano en el sistema penal acusatorio, 2a. ed., México, Anaya Editores, 2015, p. 50. 
en este caso el perteneciente al derecho administrativo sancionador, para la protección de los derechos. ${ }^{103}$

Desde luego, nuestro país requiere de un procedimiento administrativo en el que la garantía de presunción de no responsabilidad esté presente en todas las etapas, desde su inicio hasta la terminación, como baluarte de la dignidad y libertad del agente aduanal para confrontar, en su caso, violaciones procesales o sustantivas por más sutiles o mínimas que parezcan. Visto de otra forma, su violación es más factible de actualizarse con la mayor naturalidad, como suele acontecer en diversos casos en los que se aplica una medida cautelar como sanción anticipada, sin observar la garantía de no responsabilidad.

Nos enfrentamos así ante la necesidad de que la Ley Aduanera, en consonancia con los instrumentos internacionales y la Constitución Política de los Estados Unidos Mexicanos, incorpore expresamente la garantía de presunción de no responsabilidad. Una ponderación tendente a otorgar mayor beneficio y protección a la persona debe atravesar las disposiciones que sean mayormente propensas a ser quebrantadas porque se regulan con tanta generalidad que provocan una amplia discrecionalidad.

Es conveniente iniciar por las disposiciones básicas del procedimiento administrativo para que, a partir de ellas, emerja y se desarrolle la garantía de presunción de no responsabilidad que busque concretar las reformas de junio de 2008 y 2011, con la finalidad de promover e instar a establecer una política administrativa democrática, transparente y que implique una respuesta a las demandas de justicia administrativa, en el contexto del fortalecimiento del Estado constitucional de derecho.

El reto será el reconocimiento expreso de este principio como línea estructural en el procedimiento administrativo, con la finalidad de proteger la condición de inocencia, con la premisa ma-

103 Véase Reyes Sánchez, Sinuhé, La sanción administrativa, México, Novum, 2015, p. 127. 
yor de la presunción, desde el inicio del procedimiento hasta su terminación. El más elemental sentido de justicia mediante una defensa adecuada exige que se garantice a la persona un trato digno y respetuoso de sus derechos. Por esa razón, deben modificarse cualitativamente algunas disposiciones de la Ley Aduanera.

Atendiendo a lo anterior, la suspensión al agente aduanal en sus funciones, como medida cautelar, debe darse en un contexto en el que la pretensión incriminatoria de la autoridad aduanera tenga un fundamento razonable, esto es, que haya indicios racionales sobre alguna de las causas de suspensión que refiere el artículo 164, fracciones I y V, de la Ley Aduanera, pues de lo contrario vendría a garantizarse, nada menos que a costa del disfrute y ejercicio de un derecho, un procedimiento cuyo objeto pudiera desvanecerse, porque aún no se halla jurídicamente establecida la responsabilidad del agente aduanal en alguna de las causales de cancelación de la patente que describe el artículo 165 de la Ley Aduanera.

Por ejemplo, el nuevo Código Nacional de Procedimientos Penales establece en el artículo 156, intitulado "proporcionalidad", que

El juez de control, al imponer una o varias de las medidas cautelares previstas en este Código, deberá tomar en consideración los argumentos que las partes ofrezcan o la justificación que el Ministerio Público realice, aplicando el criterio de mínima intervención según las circunstancias particulares de cada persona, en términos de lo dispuesto en el artículo 19 de la Constitución.

Para determinar la idoneidad y proporcionalidad de la medida, se podrá tomar en consideración el análisis de evaluación de riesgo realizado por personal especializado en la materia, de manera objetiva, imparcial y neutral en términos de la legislación aplicable.

En la resolución respectiva, el juez de control deberá justificar las razones por las que la medida cautelar impuesta es la que resulta menos lesiva para el imputado. 
De ahí que la prueba de culpabilidad debería afirmarse en este procedimiento con enunciados lógicamente construidos que constituyen el sistema de referencia de la función del agente aduanal. Por tanto, la medida cautelar de suspensión del agente aduanal en el ejercicio de sus funciones es inaceptable. Para que esto no sea una perogrullada o una trivialidad es necesario reconocer la siguiente consecuencia: cada fase del procedimiento administrativo en el contexto del debido proceso obliga a reinterpretar los fundamentos mismos de la actividad estatal en la regulación de las relaciones sociales, tal y como habían sido previamente delimitados en la Declaración Universal de los Derechos del Hombre.

Una afirmación de culpabilidad en estos casos ha de ser objeto de una prueba tan rigurosa que sea capaz de resistir cualquier objeción, por mínima que sea, y de persuadir, por tanto, a cualquier autoridad que padezca un prejuicio contrario. La distancia entre este acontecimiento y lo que sucede en la práctica constante de la actividad aduanera es la que existe entre el procedimiento administrativo sancionador que hay y el que aspiramos a tener.

\section{ASPEGTOS SUSTANTIVOS}

El inicio del procedimiento administrativo debe estar justificado con material probatorio que determine la decisión de la apertura. Los elementos de prueba que lo integran son empleados para resolver la suspensión en el ejercicio de funciones del agente aduanal, porque probablemente ha incurrido en alguna infracción a la Ley Aduanera que contempla el artículo 165. Por tanto, incorporar la exigencia de probar con motivos suficientes la suspensión en el ejercicio de funciones, aunque sea como medida cautelar, tiene sus implicaciones prácticas en la resolución definitiva.

El agente aduanal que recibe una suspensión en los términos del artículo 167 de la Ley Aduanera, cuando la autoridad administrativa inicia el procedimiento de oficio, entre otras obligaciones, tiene el imperativo de cumplir con las formalidades esenciales 
del procedimiento que resultan necesarias para garantizar la defensa adecuada.

Guando el agente aduanal ofrezca pruebas buscará primordialmente persuadir a la autoridad aduanera de la innecesaria decisión de ordenar como medida cautelar la suspensión en el ejercicio de funciones, ya que, en ocasiones, la determinación está basada en especulaciones o hipótesis endebles que proyectan sólo una posibilidad de infracción a la ley administrativa en las diversas actividades que lleva a cabo el agente aduanal.

Desde luego, es importante que la decisión de la autoridad administrativa que recae para los casos previstos en el artículo 167 de la Ley Aduanera abra la posibilidad de un procedimiento probatorio expedito y flexible, para que el agente aduanal haga uso de la contradicción frente a la autoridad que inició el procedimiento de cancelación.

Esto indudablemente produce determinadas consecuencias en la práctica jurídica, que afectan los derechos del agente aduanal y de los terceros a los que representa, al ordenarse bajo esas condiciones de ilicitud, como medida cautelar, la suspensión en el ejercicio de sus funciones.

El procedimiento administrativo que aplica previamente y al inicio una medida cautelar de suspensión en el ejercicio de funciones excluye la garantía de audiencia y afecta la defensa adecuada porque rechaza de entrada la incorporación de cualquier tipo de medio de prueba.

Un ejemplo de lo anterior es el criterio sustentado por el Segundo Tribunal Colegiado en Materias Penal y Administrativa del Décimo Séptimo Circuito, que sostuvo:

El artículo 53, fracción II, de la Ley Aduanera prevé que los agentes aduanales son responsables solidarios del pago de los impuestos al comercio exterior y de las demás contribuciones, así como de las cuotas compensatorias causadas con motivo de la introducción de mercancías al territorio nacional, y el artículo 41, último párrafo, de la citada ley impone a la autoridad aduanera la obligación de notificar el procedimiento administrativo iniciado con 
posterioridad al despacho aduanero, tanto al comitente según se trate del importador o exportador, como al agente aduanal. Ahora bien, de la interpretación armónica de estos artículos, se concluye que la intención del legislador al establecer en el primero de ellos una solidaridad contributiva, y en el segundo un litisconsorcio pasivo necesario, fue respetar ampliamente la garantía de audiencia y defensa del obligado principal y del solidario, a efecto de que pudieran contar con los elementos probatorios que cada litisconsorte considerara conducentes; por tanto, es claro que esta figura jurídica autoriza a cualquier litisconsorte a impugnar la resolución determinante de un crédito fiscal que debe cubrir de manera solidaria y, por ende, si sólo a uno de ellos se le llamó al procedimiento, resulta innegable que a éste le afectó en sus defensas el que no se oyera al otro, quien pudo haber cubierto los impuestos materia de dicho procedimiento administrativo o bien aportar pruebas para hacer improcedente su cobro y, consecuentemente, la violación procesal derivada de la falta de notificación en comento puede combatirse por la afectación jurídica señalada. ${ }^{104}$

Esto ocurre así en el sistema jurídico mexicano. La anticipada decisión de esta medida cautelar impide efectuar el análisis cuando ha iniciado el procedimiento de todos los medios de investigación presuntamente lícitos, los que aún no han adquirido la categoría de prueba ni han sido valorados como tales por la autoridad.

Como lo mencionamos, esta configuración del procedimiento administrativo que inicia, limita irremediablemente la defensa en la medida en que el agente aduanal no tiene intervención en dicha fase, o si llega a tenerla durante la apertura del procedimiento, cuando se le corre traslado para el ofrecimiento de medios de prueba, quizás en algunos casos ya sea una defensa tardía o limitada que afecta el debido proceso legal.

104 Tesis de jurisprudencia XVII.2o.P.A.J/3, Segundo Tribunal Colegiado en Materias Penal y Administrativa del Décimo Séptimo Circuito, Semanario Judicial de la Federación y su Gaceta, Novena Época, t. XXIII, enero de 2006, p. 2298. 
El supuesto invocado abre la posibilidad de que la autoridad aduanera tenga competencia para examinar, en el marco de una revisión preliminar, los medios de investigación que tomará en cuenta para el inicio del procedimiento administrativo de cancelación de la patente del agente aduanal y que considere, previo a la aplicación de la suspensión como medida cautelar, la exclusión de la prueba, con la finalidad de que cesen los efectos nocivos que trae consigo, por los posibles perjuicios que originaría la ilicitud en el desarrollo y conclusión del citado procedimiento.

Conocer la lógica del funcionamiento del procedimiento probatorio en materia administrativa implica reconocer la necesidad de aplicar la garantía de presunción de no responsabilidad como una línea estructural que exige el debido proceso. En torno a la prueba aparece la necesidad de aplicación o no de la ley que regula las diversas causas de suspensión.

En el procedimiento administrativo de cancelación de la patente del agente aduanal, por las causales previstas en el artículo 165 de la Ley Aduanera vigente, igualmente el procedimiento probatorio tendrá que ajustarse a las reglas del debido proceso.

Por sí misma, la medida cautelar que impone la suspensión provisional cuando se trata de causales de cancelación provoca una grave violación al debido proceso y a la garantía de presunción de no responsabilidad. El artículo 167, párrafo 3, de la Ley Aduanera textualmente establece: "cuando se trate de causales de cancelación, las autoridades aduaneras ordenarán desde el inicio del procedimiento la suspensión provisional en tanto se dicte la resolución correspondiente".

Aunque en el procedimiento administrativo puedan tomarse medidas cautelares provisionales o de seguridad para garantizar la eficacia de la actuación de la administración y salvaguardar el interés público, la medida de suspensión en el ejercicio de funciones sobre la patente otorgada al agente aduanal no justifica de ninguna manera que se vulnere la garantía de audiencia como elemento del debido proceso. En una ponderación racional de 
principios y reglas, aquélla no puede ser afectada por el interés público.

La suspensión provisional en el ejercicio de funciones del agente aduanal exige necesariamente la garantía de audiencia que le permita introducir prueba que en su momento demuestre que la acción o acciones realizadas no justifican esa medida cautelar, en los términos en que la ordena el artículo 167 de la Ley Aduanera.

Por lo tanto, la decisión de la autoridad aduanera sobre la suspensión en el ejercicio de las funciones al agente aduanal, que contemplan las mencionadas disposiciones legales, indudablemente viola el debido proceso y la garantía de presunción de no responsabilidad, en razón de que no hay oportunidad alguna de probar previamente la falsedad o veracidad de la incriminación que formula la autoridad aduanera contra el agente aduanal respecto a la existencia de una causa de cancelación, o bien la ineficacia de la medida cautelar.

No cabe duda, pues, que la decisión inicial de la suspensión provisional como medida cautelar causa un grave daño en la esfera de los derechos fundamentales del agente aduanal, paraliza la función e incumple con los principios del procedimiento administrativo de economía, eficacia y eficiencia. Ello porque el agente aduanal tiene que continuar el proceso bajo la suspensión de la función que le otorga la patente hasta que se produzca la resolución definitiva que en derecho corresponda. Y probablemente en la decisión final ocurra un pronunciamiento favorable hacia su actuación, porque demuestre la inexistencia de la causa de cancelación o, en su caso, una justificación plena de la acción realizada para obrar de una forma distinta a la que indica la norma en el artículo 165 de la Ley Aduanera.

Consecuentemente, no hay razón alguna para establecer una decisión discrecional al inicio del procedimiento administrativo, sin el cumplimiento de las garantías del debido proceso y la aplicación irrestricta de los principios del procedimiento administrativo. 


\section{CAPÍTULO QUiNTO}

\section{APLICACIÓN DE LA GARANTÍA DE PRESUNGIÓN DE NO RESPONSABILIDAD EN EL ÁMBITO ADMINISTRATIVO}

En el análisis de la problemática de la aplicación de la garantía de presunción de no responsabilidad como derecho humano en las actividades del agente aduanal puede afirmarse, sin temor a equivocación, que la autoridad aduanera controla todos los aspectos relacionados con la decisión de llevar a cabo, como medida cautelar, una suspensión en el ejercicio de sus funciones al agente aduanal, cuando ordena la apertura del procedimiento administrativo sancionador. Controla el número y la calidad de los elementos de prueba que son empleados para llevar a cabo la motivación que justifica la resolución de suspensión, prescindiendo de la garantía de audiencia bajo el pretexto del carácter urgente de la determinación y la eficacia de la actuación de la administración.

En cambio, en el nuevo sistema de justicia penal acusatorio con tendencia adversarial:

Las solicitudes de medidas cautelares serán resueltas por el juez de control, en audiencia y con presencia de las partes.

El juez de control podrá imponer una de las medidas cautelares previstas en este Código, o combinar varias de ellas según resulte adecuado al caso, o imponer una diversa a la solicitada siempre que no sea más grave. Sólo el Ministerio Público podrá solicitar la prisión preventiva, la cual no podrá combinarse con otras medidas cautelares previstas en este Código, salvo el em- 
bargo precautorio o la inmovilización de cuentas y demás valores que se encuentren en el sistema financiero.

En ningún caso el juez de control está autorizado a aplicar medidas cautelares sin tomar en cuenta el objeto o la finalidad de las mismas ni a aplicar medidas más graves que las previstas en el presente Código. ${ }^{105}$

En cambio, en el procedimiento administrativo sancionador que se analiza, la autoridad aduanera controla el tiempo que el agente aduanal pasará en una situación de incertidumbre en cuanto al ejercicio de sus funciones sobre la patente otorgada, es decir, el tiempo que deberá permanecer en el banquillo del acusado. Restringe sin la garantía de audiencia la esfera jurídica del agente aduanal y de los terceros que representa con motivo de su patente. Por ende, es justo decir que es en la apertura del procedimiento administrativo sancionador donde la autoridad aduanera cuenta con mayor libertad para lesionar los derechos del agente aduanal y de terceros, ante la inaplicación de la garantía de audiencia previa, entre otras.

Por esas razones, las diligencias acordadas en el curso de una investigación acerca de las funciones realizadas en un caso concreto por el agente aduanal, en la que se inmiscuya o coarten los derechos fundamentales y libertades públicas, cualquier medida cautelar urgente habrá de estar debidamente motivada en la resolución que así lo determine, ser necesaria y adecuada al fin que con la misma se persigue y practicarse el acto de autoridad con el cumplimiento previo de todas las garantías constitucionales. ${ }^{106}$

De lo contrario se estaría legitimando, con la excusa de seguirse un procedimiento administrativo por actualizarse una de

105 Artículo 157 (imposición de medidas cautelares) del Código Nacional de Procedimientos Penales.

106 Véase López Olvera, Miguel Alejandro, "Las medidas cautelares en el derecho administrativo mexicano", en Hernández-Mendible, Víctor (coord.), Desafios del derecho administrativo contemporáneo. Conmemoración del centenario internacional de la cátedra de derecho administrativo en Venezuela, Caracas, Ediciones Paredes, 2009, t. I. 
las causas de suspensión, una suerte de inquisición general incompatible con los principios que inspiran el derecho administrativo sancionador en un Estado constitucional de derecho. Actuar en consecuencia a este sistema implica que la presunción de inocencia atraviese todo el procedimiento administrativo sancionador, tanto en cada una de sus fases consideradas individualmente, como en su configuración global.

Debe introducirse y cumplirse inmediatamente con el derecho de acceso al procedimiento administrativo que estará condicionado por la exigencia de la denominada ponderación provisional de la verosimilitud de la imputación para que proceda la restricción de los derechos del agente aduanal.

Ha de basarse en una hipótesis fundada o, lo que es lo mismo, en la concurrencia de motivos o indicios respecto a la comisión de la infracción administrativa, y proyectarse posteriormente sobre cada una de las fases del procedimiento: en su comienzo, con la apertura de la investigación; en la adopción de medidas cautelares; en la imputación y formalización del procedimiento, en el desahogo de medios de prueba que finalmente dará lugar a una decisión de la autoridad administrativa.

La garantía de presunción de no responsabilidad y el procedimiento administrativo sancionador, aunque no parecen estar conceptualmente ligados, apelan al mismo núcleo valorativo: la dignidad del hombre, que obliga a tratar a cualquier persona sujeta a investigación con estricto respeto a sus derechos, con el objeto de verificar si en el caso específico estuvo presente alguna causa que legalmente motiva la suspensión de las funciones; por tanto, el agente aduanal deberá ser tratado como sujeto de derechos, quedando proscrita la intención de tomarlo como objeto de una investigación.

La especial exigencia de imparcialidad ${ }^{107}$ que debe poseer la autoridad que resuelve sobre la causa de suspensión atribuida

107 Véase el artículo 8o. de la Convención Americana sobre Derechos Humanos. 
a algún agente aduanal ha de centrarse objetivamente en el debate que se presenta entre la autoridad aduanera que investiga y el agente aduanal, pero siempre dialécticamente luchando en igualdad de condiciones y de reglas procesales que lleven al conocimiento cierto o probable de lo ocurrido en una determinada actividad que quizá haya vulnerado la ley y que por ello se hace acreedor a una suspensión en sus funciones. ${ }^{108}$

Es incompatible con la dignidad de la persona como derecho humano llevar a cabo actos de autoridad contra el agente aduanal que imponen, sin audiencia ni defensa adecuada previa, la suspensión en sus funciones, dado que afectan profundamente los derechos más estrechamente vinculados a la condición de la persona.

Incompatible con la dignidad humana del agente aduanal, como sujeto de derecho, sería el acto de autoridad que condene en ausencia y sin intervención de la persona investigada, porque se cierra toda posibilidad de oír directamente en justicia al agente aduanal a quien se le atribuye haber incurrido en alguna causa que justifique la suspensión de sus funciones. Por ello, es dable enfatizar que sólo desde la presunción de inocencia cobran sentido esas exigencias de defensa.

En el procedimiento administrativo sancionador iniciado de oficio, cuya finalidad se ha dicho es el interés público, pueden tomarse medidas cautelares, provisionales o de seguridad, para garantizar la eficacia de la actuación de la administración y salvaguardar el interés público. Las citadas medidas pueden ser de diverso tipo, pero exclusivamente analizaremos la suspensión (artículo 167 de la Ley Aduanera) vinculada a la aplicación de la garantía de presunción de no responsabilidad. Puesto que el

${ }^{108}$ En este procedimiento, la autoridad encargada del mismo es la Administración General de Aduanas. Véase, al respecto, la tesis aislada I.7o.A.257 ${ }^{\mathrm{a}}$, Séptimo Tribunal Colegiado en Materia Administrativa del Primer Circuito, "Autoridad aduanal. CaSO EN EL QUe TIENE ESE CARÁCTER EL ADMINISTRADOR JURÍDICO DEL SERVICIO DE ADMINISTRACIÓn TRIBUTARIA", Semanario Fudicial de la Federación y su Gaceta, t. XIX, enero de 2004, p. 1459. 
carácter urgente con el que se dicta, sin necesidad de garantía de audiencia, quebranta indudablemente esta garantía.

Asimismo, viola los principios esenciales de todo procedimiento administrativo que están incorporados en diferentes textos, tanto de origen nacional como internacional. Uno de esos principios aceptados por el derecho administrativo, que igualmente aparece vulnerado, es el principio de contradicción, que en el caso se traduce en que el agente aduanal tiene derecho a hacer valer sus intereses y a ser debidamente confrontados con el acto de molestia que impone la autoridad aduanera cuando aplica la suspensión.

Durante el procedimiento administrativo sancionador deben ser respetadas las garantías del debido proceso: la garantía de audiencia, en virtud de la cual el agente aduanal afectado por el acto de suspensión debe ser escuchado, tener acceso al expediente, obtener copias, a que se le reciban y valoren pruebas sobre la causa de suspensión que pretende aplicarse y, en su momento, la posibilidad de alegar antes de la decisión.

Por otra parte tenemos el principio de tipicidad, que, junto con el de reserva de ley, integra el núcleo fundamental del principio de legalidad en materia de sanciones y se manifiesta como una exigencia de predeterminación normativa clara y precisa de las conductas ilícitas.

En este caso, el aducido principio de tipicidad, normalmente referido a la materia penal, debe hacerse extensivo a las infracciones y sanciones administrativas que corresponden a la función del agente aduanal, enfocado al tema de la suspensión como medida cautelar, derivada de las causales que lleguen a actualizarse y que aparecen reguladas en el artículo 165 de la Ley Aduanera.

Una descripción de las citadas causales de suspensión debe gozar de tal claridad que la autoridad aduanera pueda conocer su alcance y significado. Se debería evitar cualquier imprecisión de la norma que peligrosamente, mediante interpretación, pueda llevar a la autoridad al terreno de la creación legal para suplir el vacío legal. 
No debemos olvidar que la garantía de presunción de no responsabilidad y el derecho a un proceso justo no son sino dos perspectivas de análisis de un único entramado valorativo; dos manifestaciones directas de las exigencias que dimanan de la dignidad humana, en cualquier procedimiento tendente a la restricción de derechos fundamentales, que sólo pueden tomarse en consideración separadamente para ser vistas inmediatamente después estrechamente unidas.

La presunción de no responsabilidad significa que el agente aduanal no puede ser condenado o sancionado con una suspensión sin pruebas de cargo obtenidas con todas las garantías durante la tramitación del procedimiento administrativo sancionador, ${ }^{109}$ ya que una vulneración de la garantía de presunción de no responsabilidad comporta otra del proceso justo, y, a la inversa, cualquier vulneración del proceso justo, si determina la resolución de suspensión en sus funciones al agente aduanal, vulnera de algún modo la presunción de inocencia, debido a que constituye el núcleo de la estructura del proceso justo.

$\mathrm{Al}$ inicio del procedimiento indefectiblemente la autoridad aduanera deberá expresar la prueba por la que estime demostrada la probable culpabilidad del agente aduanal "más allá de toda duda razonable", y las razones por las que esa prueba ha servido de base para formar su convicción de suspender al agente en sus funciones.

¿Cuál es el significado concreto de la garantía de presunción de no responsabilidad en el procedimiento que inicia con la suspensión en el ejercicio de funciones y se apertura para decidir sobre la cancelación de la patente otorgada al agente aduanal?, ¿cuáles son sus consecuencias prácticas?

La medida cautelar de suspensión de funciones al agente aduanal ante la probabilidad de haber incurrido en alguna infracción administrativa se realiza bajo las circunstancias más adversas. El agente aduanal afectado está en el inicio del pro-

109 Véase Pons Cànovas, Ferran, Las medidas provisionales en el procedimiento administrativo sancionador, Madrid-Barcelona, Marcial Pons, 2001, pp. 124 y 125. 
cedimiento administrativo, sin opción para derrotar las incriminaciones que le ha formulado la autoridad aduanera, ya que, sin concederle la garantía de audiencia, pretende cancelarle la patente porque considera que incurrió probablemente en alguna causa que amerita esa sanción. ${ }^{110}$

Por ende, la resolución de apertura del procedimiento administrativo sancionador que impone dicha medida cautelar es la fase del procedimiento en la que el agente aduanal tiene nulo control sobre la fuente de prueba que justifica la decisión de la autoridad aduanera. Aquí es donde cobra importancia el significado concreto de la garantía de presunción de no responsabilidad. De lo contrario, las consecuencias prácticas de ignorar este derecho afectan irremediablemente la esfera jurídica no sólo del agente aduanal, también de los terceros que representa e incluso de la economía nacional.

En este contexto, no olvidemos que el necesario juicio previo es una garantía básica, una fórmula sintética que señala el punto de máxima vigencia de todas las garantías constitucionales referidas en el procedimiento administrativo sancionador. La primera derivación de esa garantía es el mandato constitucional de que nadie puede ser considerado culpable sin una sentencia, obtenida en un juicio, que lo declare como tal.

La garantía de presunción de inocencia fue reconocida por las más importantes declaraciones relativas a los derechos humanos: la Declaración de los Derechos del Hombre y del Ciudadano, la Declaración Universal de los Derechos Humanos y la Convención Americana sobre Derechos Humanos.

110 Por ejemplo, cuando se le suspendía por actos de su apoderado aduanal. El Primer Tribunal Colegiado del Décimo Quinto Circuito, en una tesis de jurisprudencia, señaló que "la cancelación de la patente de un agente aduanal no puede originarse en la conducta infractora de la citada legislación, por parte de su apoderado aduanal, al tratarse de hechos que no realizó, pues, en todo caso, éste es quien debe soportar las sanciones respectivas". Véase tesis de jurisprudencia XV.1o.J/16, Primer Tribunal Colegiado del Décimo Quinto Circuito, Semanario Fudicial de la Federación y su Gaceta, Novena Época, t. XXXIII, enero de 2011 , p. 2827. 
Luego entonces, cuando un agente aduanal ingresa al ámbito concreto de actuación de la autoridad aduanera tiene sentido decir que aquél es "inocente", porque eso significa que hasta el momento de la sentencia condenatoria no se le podrán aplicar consecuencias sancionadoras de orden administrativo. Por lo tanto, debemos afirmar que cuando el agente aduanal ingresa al foco de atención de las normas del procedimiento administrativo, conserva su situación básica de libertad en el ejercicio de la patente otorgada. Puesto que "nadie es culpable si una sentencia no lo declara así". En concreto, este principio significa:

a) Que sólo la resolución o la sentencia del procedimiento administrativo puede modificar el estatus de libertad del agente aduanal para ejercer o no la patente.

b) Que al momento de la resolución sólo existen dos posibilidades: el agente aduanal es culpable de la incriminación formulada en la apertura del procedimiento administrativo para la cancelación de la patente o resultó inocente de esa imputación.

c) Que la responsabilidad del agente aduanal debe ser jurídicamente construida.

d) Que esa construcción implica la adquisición de un grado de certeza.

e) Que el agente aduanal no tiene que construir su inocencia.

f) Que el agente aduanal no puede ser tratado como infractor de las incriminaciones que formula la autoridad aduanera en su contra.

g) Que no pueden existir ficciones de infracción, es decir, partes de la infracción que no necesitan ser probadas, como se ha pretendido, durante la aplicación de la suspensión del agente aduanal en el ejercicio de sus funciones.

Como puede observarse, las afirmaciones precedentes son una derivación integral de la idea misma de "juicio previo" que comprende todo el desarrollo del procedimiento administrativo, 
que debe estar atravesado por la garantía de presunción de no responsabilidad. Significa que cuando el agente aduanal es notificado del procedimiento administrativo que se apertura en su contra, llega con un estatus que debe ser destruido por la autoridad aduanera y en ello reside la construcción de la infracción.

El agente aduanal no tiene que probar su inocencia. La denominada "carga de la prueba" estará a cargo de la autoridad aduanera que mediante una determinada posición jurídica hace incriminaciones, de modo que si no logra probarlas tendrá que determinarse la inocencia.

Lo cierto e importante es que el agente aduanal está protegido constitucionalmente por la garantía de presunción de inocencia, que es de trascendental relevancia política. De ahí que la garantía de presunción de no responsabilidad también debe significar que en el procedimiento administrativo no pueden existir ficciones de "culpabilidad", que indebidamente son empleadas para imponer la medida cautelar de suspensión en el ejercicio de funciones del agente aduanal de un modo automático, sin encontrarse probada la infracción por parte de la autoridad aduanera.

Dentro del nivel de apertura del procedimiento administrativo tendrá que eliminarse, como en cualquier proceso, la sospecha o presunción de infracción. Lo importante es comprender que lo que está en juego no es ningún nivel de conocimiento, sino una garantía política que protege al agente aduanal que ingresa al ámbito de actuación de las normas del procedimiento administrativo sancionador.

No se trata de que exista una presunción de infracción o que ciertos actos impliquen necesariamente un grado mayor o menor de sospecha de que el agente aduanal violó las normas administrativas que regulan la actividad aduanera. Lo importante es que no sea considerado ni tratado como infractor mientras una sentencia no lo declare como tal, es decir, se requiere que la sanción - aunque sea provisional, como en el caso de la suspensión en el ejercicio de funciones - no sea anterior al "juicio previo" ni sea impuesta por fuera de él. 
Entenderemos por infracción el haber actuado en contra de las normas administrativas de orden prohibitivo o imperativo, pudiendo haber ajustado su actividad a lo previsto en la Ley Aduanera. Este concepto sustancial sólo puede ser producido en la sentencia o resolución que pone fin al procedimiento administrativo.

Igualmente, se debe entender que no se trata de ningún beneficio a favor del agente aduanal sino, muy por el contrario, una limitación muy precisa a la actividad sancionadora del Estado. De tal forma que esta garantía rige, fundamentalmente, como principio rector de la construcción de la resolución final como un todo, pero también sirve para interpretar o valorar algún elemento de prueba en general.

Por último, y como lógica consecuencia, si el agente aduanal no es infractor mientras no se pruebe que violentó el orden jurídico administrativo mediante una resolución que pone fin al procedimiento administrativo, de ningún modo podría ser tratado como infractor, ya que éste es el núcleo central de esta garantía que excluye la posibilidad de la sanción anticipada, como ocurre en la hipótesis que analizamos respecto de la suspensión en el ejercicio de funciones cuando ha iniciado un procedimiento para la cancelación de la patente.

Aquí, el agente aduanal está sometido a un procedimiento para que pueda defenderse. La autoridad aduanera buscará comprobar que ha violentado la norma jurídica porque considera que incurrió en alguna de las causas previstas en el artículo 165 de la Ley Aduanera que ameritan la cancelación de la patente. Por ende, el no poder ser tratado como infractor significa que tampoco se le puede anticipar alguna sanción, aunque sea temporal, como la medida cautelar ya mencionada, y también significa que no puede serle restringido el derecho de defensa. En definitiva, el agente aduanal llega al comienzo del procedimiento libre de culpa, y sólo por la sentencia o resolución que pone fin al mismo podrá, en su caso, ser declarado infractor. 


\section{HIPÓTESIS RELEVANTES E IMPLICACIONES PRÁCTICAS EN LAS ACTIVIDADES DEL AGENTE ADUANAL QUE EXIGEN LA APLICACIÓN DE LA PRESUNGIÓN DE NO RESPONSABILIDAD}

En torno a las implicaciones prácticas que tiene el estudio y aplicación de la garantía de presunción de no responsabilidad en el procedimiento administrativo sancionador que inicia con motivo de una investigación para aplicar una sanción anticipada, por haberse presentado probablemente alguna causa para ordenar la suspensión de funciones al agente aduanal, es oportuno destacar - en palabras del maestro Vives Antón- que el principio de inocencia "es la clave de la bóveda del sistema de garantías en materia penal, y también, que el contenido básico de dicha presunción es una regla de juicio, según la cual nadie puede ser condenado a un castigo a menos que su culpabilidad resulte probada, más allá de toda duda razonable, tras un proceso justo". ${ }^{111}$

Las hipótesis relevantes y que exigen el respeto de la garantía de presunción de no responsabilidad en la función del agente aduanal están circunscritas, en este caso, a: 1) la afectación directa a los derechos y esfera jurídica de la persona que tiene la calidad de agente aduanal, y 2) la violación a los principios de economía, eficacia y eficiencia del procedimiento administrativo.

1) Afectación directa a la esfera jurídica del agente por cancelación de la patente aduanal. Analizar la exigencia de la garantía de presunción de no responsabilidad en la función aduanal significa deconstruir

111 Vives Antón, Tomás S., Fundamentos del sistema penal..., cit., p. 931. 
la postura de los tribunales federales en relación con el tema. Vemos como ejemplo la idea materializada de varios juzgadores que aparece reflejada en el sentido del siguiente criterio:

Fustifica la suspensión en el ejercicio de sus funciones al agente aduanal y sostiene que no requiere el otorgamiento de la garantía de audiencia porque la mencionada suspensión "constituye una medida provisional accesoria y sumaria que pretende garantizar no sólo la eficacia de la cancelación, sino también el interés público y fiscal, y que no entraña propiamente un acto privativo de carácter definitivo, en virtud de que sólo durará hasta en tanto se dicte la resolución respectiva. Además, la referida medida tiene el carácter de cautelar, pues se adopta como reacción ante ciertos riesgos o perturbaciones aduaneras y supone, por su contenido y fin, cautelas para evitar lesiones al interés público protegido, o para impedir la continuación de sus efectos antijurídicos, dadas las infracciones consignadas en el acta de inicio del procedimiento administrativo en materia aduanera". ${ }^{112}$

2) Otra hipótesis general deriva del acto de la suspensión en el ejercicio de la función al agente aduanal. Provoca, sin la oportunidad de la garantía de audiencia, el resquebrajamiento de los fines del acto administrativo por la imposibilidad de cumplimiento de los principios de economía, eficacia y eficiencia en el procedimiento administrativo de cancelación de la patente aduanal.

No contradice esta afirmación el hecho de que se permita al agente aduanal concluir las operaciones iniciadas, validadas y pagadas antes de la notificación de inicio del procedimiento. Estas hipótesis constituyen una violación a la garantía de presunción de no responsabilidad y al debido proceso porque se convierten en una sanción anticipada sobre la que recae una resolución unilateral y en donde el agente aduanal no tuvo oportunidad de defensa.

112 Véase tesis aislada $1^{\mathrm{a}}$.LXXVIII/2001, Primera Sala, Semanario Fudicial de la Federación y su Gaceta, Novena Época, t. XIV, agosto de 2001, p. 165. 
Justamente aquí el agente aduanal debe ser tratado como persona sometida al procedimiento administrativo que se inició para la cancelación de la patente, porque existe la probabilidad de transgresión a alguna norma prohibitiva o imperativa, pero en ningún momento puede anticiparse la sanción respecto a la infracción a la norma, así calificada por la autoridad aduanera.

Sin embargo, debemos acotar ambas hipótesis. En la aplicación de una medida cautelar, como la suspensión en el ejercicio de funciones del agente aduanal, antes que relaciones jurídicas, lo que existe $-\mathrm{y}$ lo que explica la naturaleza del procedimiento administrativo - son situaciones o estados de incertidumbre. Cada sujeto adquiere - en y respecto de esa situación- deberes, facultades y, en ocasiones, expectativas. Finalmente, a través del procedimiento para la cancelación de una patente de agente aduanal y, en especial, en la resolución o sentencia, se logra superar esa incertidumbre fijando la solución legal prevista por el orden jurídico para esa situación.

De modo que juicio previo y respeto a la garantía de la presunción de no responsabilidad son mecanismos básicos en el procedimiento administrativo sancionador; a partir de ambos se construye un escudo protector frente al poder arbitrario que a menudo lesiona derechos fundamentales. La garantía de presunción de no responsabilidad en este contexto implica un "estatus de inocencia", una "presunción de inocencia", "de no responsabilidad", "de no infracción" o un "derecho a ser tratado como inocente", que para efectos prácticos no difieren en lo sustancial.

Aun cuando la realidad nos muestra, al contrario, que existe una presunción de infracción al inicio del procedimiento administrativo sancionador para la cancelación de la patente a un agente aduanal y que éste es tratado como tal, lo importante entonces resulta visualizar ambas situaciones como signos evidentes de que la garantía de presunción de no responsabilidad es un programa a realizar, una tarea pendiente en esta materia.

Tampoco debemos adoptar la superficial idea de que se trata de un simple problema coyuntural derivado de la modificación o 
reforma a la Ley Aduanera y que será remediado por sí mismo durante la práctica jurídica. Al contrario, lo correcto es considerar que las garantías constitucionales después de las reformas del 18 de junio de 2008 y 11 de junio de 2011 a la Constitución federal son espacios de lucha en los que existen avances y retrocesos, y que el derecho administrativo sancionador es, a su vez, un gran espacio de lucha en el que se juega la dignidad de la persona.

Quizá lo relevante radica en comenzar por alinear la garantía de presunción de no responsabilidad reconocida en nuestra Constitución Política de los Estados Unidos Mexicanos, a las normas que regulan la actividad del agente aduanal.

Con la reforma reciente se abre la posibilidad para que cualquier persona pueda prestar los servicios especializados de agente aduanal. Los motivos de esta regulación aparentemente están dirigidos a impulsar la competitividad nacional; al menos éste ha sido el argumento principal del discurso oficial.

La reforma plantea que "cualquier persona" puede prestar dichos servicios. El argumento sostiene que estas modificaciones a la ley buscan impulsar la competitividad nacional y es responsabilidad de los agentes aduanales - como expertos en comercio exterior y coadyuvantes del gobierno - vigilar su implementación y señalar las posibles ramificaciones, especialmente en materia de seguridad nacional y captación de impuestos. Esto permite también refrendar la competitividad de los agentes aduanales a través de su experiencia, responsabilidad y eficiencia.

Sin embargo, la competitividad de los agentes aduanales exige proporcionar un respaldo legislativo de mayor envergadura, dirigido a la transformación profesional de la figura del agente aduanal, de manera tal que lo coloque a la vanguardia de las orientaciones y tendencias que marca actualmente el comercio exterior y el Estado constitucional de derecho, en un procedimiento administrativo sancionador que admita expresamente en su legislación la garantía de presunción de no responsabilidad.

De ahí que resulta indispensable una modificación al artículo 167, tercer párrafo, de la Ley Aduanera, que proponemos bajo 
el esquema argumentativo anterior y se constrine a lo siguiente: "cuando se trate de causales de cancelación, las autoridades aduaneras ordenarán, respetando la garantía de presunción de no responsabilidad, el inicio del procedimiento".

Esta propuesta la planteamos exclusivamente para aquellos casos en los que sea imprescindible la aplicación de una medida cautelar. Por tanto, para cumplir con la garantía de presunción de no responsabilidad y el debido proceso debe adoptarse la garantía de audiencia previa a favor del agente aduanal, en la que se haga de su conocimiento que presuntamente ha incurrido en alguna de las infracciones consignadas como causales de cancelación de la patente y que se le permita probar inmediatamente que no hay necesidad de cautela, por no presentarse ningún riesgo para el interés público o fiscal, como generalmente lo argumenta la autoridad aduanera.

La adecuada normativa para el cumplimiento de la garantía de audiencia previa y, en consecuencia, del debido proceso sería aquella que sin afectación del interés público incorpore una audiencia inicial que permita al agente aduanal, mediante el principio del contradictorio, oponerse a la suspensión en el ejercicio de sus funciones en aquellos casos en que pudiera verse afectado por la decisión unilateral que inicia el procedimiento administrativo para la cancelación de la patente.

Esta audiencia procesal puede tener lugar en el auto de apertura de este procedimiento, con la exclusiva finalidad de que permita al agente aduanal o su representante legal, por ejemplo, objetar no sólo los motivos de la decisión de apertura del procedimiento, sino todos aquellos medios de prueba invocados que aparentemente lo justifican y que, en algunos casos, fueron obtenidos con inobservancia de garantías fundamentales.

La posibilidad de objeción de estos medios de prueba que motivan la decisión de la autoridad aduanera para la apertura del procedimiento de cancelación de la patente, con la consecuente suspensión en el ejercicio de funciones del agente aduanal, sería 
un mecanismo de control específico para salvaguardar el respeto de la legalidad en la limitación de derechos fundamentales.

Cabe proponer la exclusión de prueba ilícita en esta fase de apertura del procedimiento de cancelación de la patente sólo en aquellos casos en que el resultado sea irreparable por la suspensión en el ejercicio de sus funciones al agente aduanal. Las afirmaciones que funden la solicitud de exclusión serán objeto de prueba, con estándares específicos y más allá de toda duda razonable respecto a la necesidad de cautela.

Introducir esta modificación como limitante de la citada medida cautelar implicará adoptar la garantía de presunción de no responsabilidad como una línea estructural del procedimiento administrativo que fortalece el debido proceso. En este momento la autoridad aduanera determinaría si posee información suficiente para la suspensión como medida cautelar o, en su caso, debe prescindir de aplicarla para evitar un daño irreparable en la esfera jurídica del agente aduanal en el ejercicio de sus funciones. 


\section{BIBLIOGRAFÍA}

Aguilar López, Miguel Ángel, Presunción de inocencia. Derecho humano en el sistema penal acusatorio, 2a. ed., México, Anaya Editores, 2015.

AlARCÓN SOTOMAYOR, Lucía, El procedimiento administrativo sancionador y los derechos fundamentales, Madrid, Thomson-Civitas, 2007.

Álvarez Villagómez, Juan, ¿Sabe usted quién es su agente aduanal?, Consultorio fiscal, jurídico, laboral y contable-financiero, núm. 455, agosto de 2008.

Araujo-Juárez, José, Derecho administrativo. Parte general, Caracas, Venezuela, Ediciones Paredes, 2008.

ARMenta DeU, Teresa, La prueba ilícita. Un estudio comparado, 2a. ed., Madrid, Marcial Pons, 2011.

BeLtrán HernánDez, Daniel et al., La aduana, despacho aduanero y procedimientos de importación, México, IPN, 2007.

BERNAL LADRÓN DE GUEVARA, Diana, "El reconocimiento y tutela de los derechos humanos de los contribuyentes", en Ríos Granados, Gabriela (coord.), Derechos humanos de los contribuyentes, México, UNAM, 2014.

CAAAREM, El agente aduanal mexicano, México, CAAAREM, 2003.

Cancino, Rodolfo y TREjO, Pedro, Nuevo derecho aduanero electrónico, México, Novum, 2015.

Carvajal Contreras, Máximo, Derecho aduanero, México, Porrúa, 2000.

Cisneros García, Juan Rabindrana, Derecho aduanero mexicano, México, Porrúa, 2013. 
Cueva Carrión, Luis, El debido proceso, 3a. ed., Quito, Ecuador, Ediciones Cueva Carrión, 2007.

Dromi, Roberto, Derecho administrativo, Buenos Aires, Ciudad Argentina, 2001.

El acceso a la justicia como garantía de los derechos económicos, sociales y culturales. Estudios de los estándares fijados por el sistema interamericano de derechos humanos, Washington, D.C., Estados Unidos, Comisión Interamericana de Derechos Humanos, 2007, disponible en: http://wrww.cidh.org.

ESPINOZA, Ricardo, La presunción de inocencia en el sistema acusatorio mexicano, México, Novum, 2012.

Fernández RuIZ, Jorge, Derecho administrativo. Servicios públicos, México, Porrúa, 1995.

FIX-ZAMUdio, Héctor, "Consignación”, Nuevo Diccionario furídico Mexicano, México, Porrúa-UNAM, t. A-C.

GARBERÍ LlOBREGAT, José, Derecho administrativo sancionador práctico, 2 vols., Madrid, Bosch, 2012.

García Arredondo, Jaime Armando, Derecho aduanero, México, Themis, 2013.

GóngORA PIMENTEL, Genaro David, El reconocimiento del derecho administrativo sancionador en la jurisprudencia constitucional mexicana, México, disponible en: wrw.juridicas.unam.mx.

GonzÁlez Ruiz, Samuel Antonio, "Capacidad”, Diccionario Furídico Mexicano, México, Porrúa-UNAM, 2011.

HeRnÁndez EsPíndola, Olga, "Permiso administrativo", Nuevo Diccionario Jurídico Mexicano, México, Porrúa-UNAM, 2001, t. P-Z.

Herrera PÉrez, Alberto, El derecho a la presunción de inocencia, México, Porrúa, 2012.

IBÁÑEZ RIVAS, Juana María, "Artículo 8. Garantías judiciales", en STeINer, Christian y URIBE, Patricia (coords.), Convención Americana sobre Derechos Humanos comentada, México, SCJN-Konrad Adenauer Stiftung, 2014. 
López Monroy, José de Jesús, "Mandato", Nuevo Diccionario Furidico Mexicano, México, Porrúa-UNAM, 2001, t. I-O.

LÓPEz OlverA, Miguel Alejandro, El control de convencionalidad en la administración pública, México, Novum, 2014.

LóPez Olvera, Miguel Alejandro, "Las medidas cautelares en el derecho administrativo mexicano", en HERNÁNDEZ-MENDIBLE, Víctor (coord.), Desafios del derecho administrativo contemporáneo. Conmemoración del centenario internacional de la cátedra de derecho administrativo en Venezuela, Caracas, Ediciones Paredes, 2009, t. I.

López Olvera, Miguel Alejandro y Pahuamba Rosas, Baltazar, Nuevos paradigmas constitucionales, México, ESPRESS, 2014.

Mabarak Cerecedo, Doricela, "El agente aduanal y su intervención en los despachos", en MARTínez VerA, Rogelio y Mabarak Cerecedo, Doricela, 7 estudios jurídicos, México, Asociación Nacional de Abogados-Academia Mexicana de Documentación Jurídica, 1979.

NiETo García, Alejandro, Derecho administrativo sancionador, Madrid, Tecnos, 2008.

Oropeza García, Arturo (coord.), El comercio exterior y la gestión aduanal en el siglo XXI, México, UNAM-AAADAM.

Ossa ARbeláez, Jaime, Derecho administrativo sancionador. Hacia una teoría generaly una aproximación a su autonomía, Bogotá, Legis, 2000.

Ovilla Mandujano, Manuel, Adunas, México, s.e., 1976.

PinedA, Fanny, "Servicio público", Diccionario Furídico Mexicano, México, Porrúa-UNAM, 2011, t. P-Z.

Pons CÀnovas, Ferran, Las medidas provisionales en el procedimiento administrativo sancionador, Madrid-Barcelona, Marcial Pons, 2001.

Ramírez GutiérRez, José Othón, "Agentes aduanales", Diccionario Furídico Mexicano, México, Porrúa-UNAM, 2011, t. A-C.

Rangel Medina, David, "Patentes", Diccionario furídico Mexicano, México, Porrúa-UNAM, 2011, t. P-Z.

Reyes DíAZ-LEAL, Eduardo, El despacho aduanal, México, 2003. 
REyes DÍAZ-LEAL, Eduardo, Reformas para tu comercio exterior 2010 , México, 2010.

Reyes SÁnchez, Sinuhé, La sanción administrativa, México, Novum, 2015.

Rohde Ponce, Andrés, Derecho aduanero mexicano, México, Ediciones Fiscales ISEF, 2000.

Roldán Xopa, José, Derecho administrativo, México, Oxford University Press, 2008.

Salgado Ledesma, Eréndira, "Capítulo tercero. Función pública”, en Olivos Campos, José René (coord.), Derecho administrativo, México, Porrúa, 2014.

SCHAFFlER, Federico, CAAAREM. Origen y evolución, México, CAAAREM, 2013.

Soberón Mainero, Miguel, "Representación", Diccionario furídico Mexicano, México, Porrúa-UNAM, 2011, t. P-Z.

Trejo VARgas, Pedro, Aduanas, régimen juridico y facilitación, México, Porrúa, 2008.

Trejo Vargas, Pedro, El sistema aduanero de México, México, Servicio de Administración Tributaria, 2003.

UGARTE ROMERO, Luis, Ley, convenios, tratados y otros temas de aeronáutica civil, México, AAADAM, 1995.

VÁzQUEz, Luis Daniel y SERRANO, Sandra, "Los principios de universalidad, interdependencia, indivisibilidad y progresividad. Apuntes para su aplicación”, en CARBOnELL, Miguel y SALAZAR, Pedro (coords.), La reforma constitucional de derechos humanos: un nuevo paradigma, México, UNAM, 2011.

VELÁZQUEZ EliZARRARÁs, Miguel Ángel, Ley aduanera comentada. Legislación, jurisprudencia y doctrina, México, Themis, 1990.

Vives Antón, Tomás S., Fundamentos del sistema penal. Acción significativa y derechos constitucionales, 2a. ed., Valencia, Tirant lo Blanch, 2011.

WITKER, Jorge, Derecho del comercio exterior, México, UNAM-AAADAM, 2011.

WITKER, Jorge, Derecho tributario aduanero, México, UNAM, 1999. 
I agente aduanal es una persona física que desempeña un papel muy relevante en la compleja cadena de muchos de los procedimienientos que se realizan en la aduana y que son apoyo indispensable para los importadores y exportadores.

En la presente obra se analizan, desde una óptica crítica, temas como su denominación, la autoridad que otorga la patente, los diferentes nombres que le ha dado la ley a través de la historia, los requisitos para obtener la patente, y para operar, así como los derechos que tiene en su carácter de agente aduanal. También se analiza la posibilidad de regulación de la figura de la agencia aduanal y se propone un esquema para que sea incorporado, como un capítulo o sección, dentro de la Ley Aduanera.

Se describe y analiza el procedimiento del despacho aduanero, poniendo énfasis en las responsabilidades del agente aduanal y de las personas que intervienen en ese procedimiento. Se estudia todo lo relativo a la función de vigilancia, por parte del Estado, de las actividades de los agentes aduanales. También se analiza la garantía de la presunción de inocencia y su aplicación en los procedimientos administrativos sanciondores en contra de agentes aduanales, que el autor denomina como presunción de no responsabilidad.
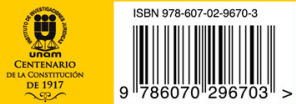